\title{
STACHKA: UM ENSAIO SOBRE OS ANTAGONISMOS
}

Dissertação apresentada ao Programa de PósGraduação em Artes Visuais, Área de Concentração: Teoria, Ensino e Aprendizagem da Arte, Linha de Pesquisa: História, Crítica e Teoria, da Escola de Comunicações e Artes da Universidade de São Paulo, como exigência parcial para obtenção do Título de Mestre em Artes, sob a orientação do Prof. Dr. Luiz Renato Martins. 


\section{RISUMO}

O presente trabalho analisa a maneira como a noção de "encomenda social" se apresenta na obra do cineasta soviético Sergei M. Eisenstein (1898-1948), em seu primeiro filme - A Greve (Stachka, URSS, 1925) -, no âmbito de sua relação com o Construtivismo Russo (vanguarda artística soviética, que perdurou nos primeiros anos da década de 1920) e o movimento da Cultura Proletária (Proletkult)

A análise parte da perspectiva proposta pelo historiador François Albera, em Eisenstein et Le Constructivisme Russe (1989), que considera, como fundamento da atividade artística construtivista, sua preocupação com a dimensão social da pratica artística. Para Albera, a noção de "encomenda social", na acepção do escritor e dramaturgo Sergei Tret'iakov (1892-1937), é um conceito chave para se entender como os artistas construtivistas compreendiam sua missão social.

A pesquisa realizada demonstrou que a teoria da "montagem de atrações" de Eisenstein se constituiu num modo de construção artística, nos âmbitos do teatro e do cinema, que tinha como diretriz o trabalho com as emoções do espectador. Tal forma de práxis artística, articulada ao conceito de "encomenda social", ligava-se à nova escala da luta de classes, na chave posta pela implementação da Nova Política Econômica (NEP).

Palavras Chave: Eisenstein, A Greve (Stachka, URSS, 1925), Encomenda Social, Proletkult, NEP 


\section{ABS'TRAC'T}

The present work analyzes how the concept of "social command" is presented in the work of Soviet filmmaker Sergei M. Eisenstein (1898-1946) in his first film Strike (Stachka, USSR, 1925) - within the sphere of his relationship with Russian Constructivism (Soviet artistic avant-garde, which lasted in the early years of the 1920s) and the Proletarian Culture (Proletkult) movement.

The analysis starts with the approach proposed by the historian François Albera, who considers the social dimension of artistic practice as the foundation for constructivist artistic activity. For Albera, the notion of "social command" as defined by the writer and dramatist Sergei Tret'iakov (1892-1937), is a key concept for understanding how constructivist artists understand their social mission.

The research presented demonstrates that the theory of "montage of attractions", developed by Eisenstein, constitutes a mode of artistic construction which shapes the emotions of the spectator in both theater as well as cinema. This form of artistic practice, articulated by the concept of "social command", is linked to a new level of class struggle as produced by the implementation of the New Economic Policy (NEP).

Keywords: Eisenstein, Strike (Stachka, URSS, 1925), Social Command, Proletkult, NEP. 


\title{
COMISSÃO JULGADORA
}

\author{
Orientador
}

1‥ Titular / Suplente

2o. Titular / Suplente

São Paulo, de de 


\section{STACHKA: \\ UM ENSAIO SOBRE OS ANTAGONISMOS}

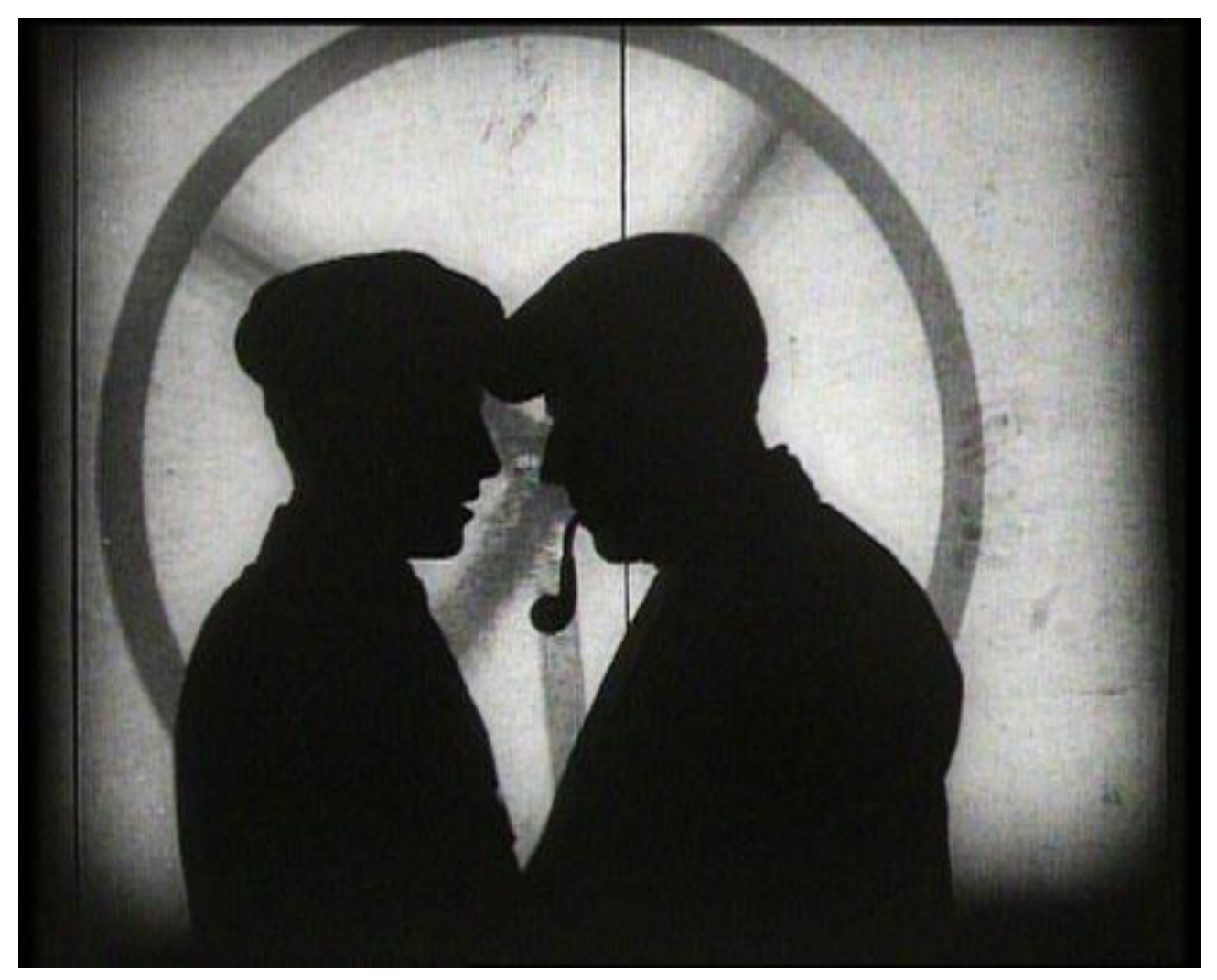

PETERSON SOARES PESSOA 
Pain, makes me stronger

Everyday

Life is chaos

You gotta deal with it

Expressing my aggressions

Through confusion

Face reality

Nothing is like it used to be

Sepultura - Clenched Fist 


\section{AGRADICIMEN'TOS}

Este trabalho deve muito a algumas pessoas, por diversas razões, e eu gostaria de agradecer a todas elas. Todavia, a ansiedade e o nervosismo são grandes. Portanto, peço desculpas se eu me esquecer de algum de vocês, caros amigos (as), colegas, pesquisadores, etc.

Gostaria de agradecer:

Ao meu orientador, Luiz Renato Martins (não consigo imaginar um leitor mais rigoroso, dedicado e "empolgado"), aos colegas do Centro DESFORMAS, à minha primeira orientadora, Leca Kangussu (e também aos professores da UFOP que contribuíram para minha formação: Zé Luiz, Romero, Olímpio, etc.), à FAPESP e a CAPES (pelas bolsas concedidas).

Aos meus companheiros de Casa Rosada: Gabi "Alexanderplatz" Bittencourt e Daniel "Chronos" Garroux (sem vocês essa dissertação não teria saído); Rodrigo "Suíno" Dantas, Taylor McCarthy; Ricardo Criciúma e Maria Carlotto; Thiago "Pancadaria" Tenório, Picachu, Érico, e todos os demais "rosados" (de fato e de direito) que participaram e ainda participam da minha vida nessa casa.

Aos churrasqueiros de plantão do CRUSP: Arthur "Malvadeza" Klik (se não fosse por você, camarada, eu não teria caído de pára-quedas nessas terras uspianas), Paulão, Gustavo "Batavo" Trossini.

Aos meus eternos amigos de Belo Horizonte: Zé "True Black Metal", Bruno "Valderrama", Bruno "Pivete", Flávio Makoto, André, Gabriel, e todos os parceiros (as) dessa nossa turma boa que freqüenta a cena dos botecos de $\mathrm{BH}$.

Aos meus companheiros inseparáveis que participam e participaram do Thespian: Humberto "Neanderthal" Grilli, Marcus "Quinho" Raveli, Ronie Damasceno, Reinaldo Damasceno, e Reinaldo Figueiredo.

A todos os amigos/companheiros/camaradas da APG/USP - Capital (2008-2009).

Á Carla Marques, moça que conquistou meu carinho e afeto, nos momentos finais deste trabalho

A toda minha família, especialmente minha mãe, Selma Teixeira Soares (pela árdua luta que travou para criar um filho), e meu avô, Clemente Soares Sobrinho (uma pessoa que sempre soube, com sabedoria, valorizar e apreciar o hábito do estudo) 


\section{SUMÁRIO}

\section{Introdução: 01}

Primeiro Capítulo: A Greve: uma rememoração da questão da organização política do proletariado no contexto da NEP

I Introdução: 07

II 1905: 11

III 1917: o primeiro governo operário e camponês: 15

IV NEP: "aumentar a produtividade do trabalho e socializar a produção na prática": 21

V Rumo à construção do cinema soviético: 1924-1925: 28

VI Continuar a Revolução... 42

Segundo Capítulo: Construtivismo e Cinema

I Construtivismo: a organização e o uso utilitário dos materiais: 47

II Produtivismo: a produção artística em diálogo com as necessidades da produção industrial: $\mathbf{5 6}$

III O debate sobre a kinematografiya: "encenado" versus "não encenado": 61

IV O cinema e a "Encomenda Social": 72

Terceiro Capítulo: O espectador como material cinematográfico

I Eisenstein: do Exército Vermelho à Cultura Proletária: 80

II A montagem de atrações: 90

III A montagem de atrações no cinema: 96

IV As possibilidades criativas do cinema ficcional: 102

Quarto Capítulo: Stachka (A Greve)

I Um ensaio sobre os antagonismos: 106

II Estranhamento: a arte cinematográfica como deslocamento entre a imagem e o objeto filmado: 124

III A estilização como ferramenta eficaz para introduzir o espectador na ação e na trama: 127

IV A Greve: uma montagem de "coisas reais" (vechtch): $\mathbf{1 3 1}$

Conclusão: 142

Bibliografia:144 


\section{INTRODUĈ̣̃̃}

Hoje, a expressão sotzialny zankaz, "encomenda social", está na moda [...], mas devemos entender com isso a encomenda de um organismo governamental? Seria um grande erro [...] A encomenda social não surge no gabinete de um diretor de estúdio [cinematográfico], nem em uma comissão de Estado. Eisenstein obteve sua encomenda junto à revolução proletária, no curso do qual ele se tornou um artista. Essa demanda social não chegou até ele na forma de uma resolução ou proposta de filme, mas como um processo orgânico de evolução da Revolução e da evolução de Eisenstein.

Estamos persuadidos de que ainda que o próximo filme de Eisenstein não proceda de um pedido da VTISIK (Comitê Executivo Central de Toda a Rússia do Partido Comunista [Bolchevique]) e que seu roteiro não trate de um tema que concerne à Revolução, Eisenstein, entretanto, responderá à encomenda social do proletariado. ${ }^{1}$

Maior produção soviética no ano de 1925, A Greve (Stachka) é a reposta de Eisenstein a uma necessidade do cinema soviético, até então saturado de produções estrangeiras, principalmente provenientes da Alemanha. A política da Goskino, empresa criada pelo governo bolchevique em 1922, para controlar a produção, distribuição, importação e aquisição de materiais de produção, havia priorizado a importação de títulos estrangeiros a fim de gerar lucros rapidamente, tendo em vista a escassez dos recursos materiais para a produção e a exibição de filmes. Embora o governo revolucionário julgasse o cinema uma arte estratégica e ferramenta potente para o esclarecimento dos

\footnotetext{
${ }^{1}$ Kino-Gazeta, 12/01/1926, citado por Kleiman e Levina, O Encouraçado Potemkin, p. 213, apud. ALBERA, François, Eisenstein e o Construtivismo Russo, trad. Eloísa Araújo Ribeiro, pref. Luiz Renato Martins, São Paulo, Cosac \& Naify Edições, 2002, p. 260.
} 
trabalhadores, o repasse de verbas para a produção local mostrava-se insuficiente para competir com a política emergencial de importações. ${ }^{2}$

Deve-se ressaltar que o ano de 1924 foi decisivo para o cinema soviético. ${ }^{3}$ Com a criação da Sovkino, empresa formada para corrigir a crise decorrente das falhas de produção e distribuição da sua antecessora, a Goskino, e com o vislumbre de uma estabilidade econômica gerada pelos primeiros anos da НЭП (Novaya Ekonomiceskaya Politika - Nova Política Econômica, 1921-1928), Eisenstein encontrou uma brecha para elaborar uma proposta cinematográfica que pudesse ser de fato proletária.

Ainda que obras precedentes, como Diabos Vermelhos ${ }^{4}$, de Ivane Perestrani (1870-1959), e Extraordinárias Aventuras de Mr. West na Terra dos Bolcheviques, ${ }^{5}$ de Lev Kuleshov (1899-1970), tivessem uma boa recepção por parte do público, tendo apresentado avanços em relação à cinematografia americana (no sentido da experimentação com a montagem e da apresentação de temas soviéticos), a crítica da época ${ }^{6}$ destacou Stachka como um novo caminho para o cinema revolucionário soviético.

\footnotetext{
${ }^{2}$ A historiadora Denise Youngblood ressalta a importância e a influência do político I. P. Trainin, bolchevique ligado ao partido desde 1905 e porta-voz da Sovkino, no incentivo à importação de filmes estrangeiros de entretenimento, e ao estabelecimento de uma base comercial para o cinema soviético. Sobre esse assunto, ver YOUNGBLOOD, Denise, Soviet Cinema in the Silent Era 1918-1935, Austin, University Of Texas Press, 1991.

${ }^{3}$ De acordo com Youngblood e Kristin Thompson, baseados nos trabalhos dos historiadores Jay Leyda e Richard Taylor, a importação de filmes estrangeiros foi crucial para a recuperação da indústria cinematográfica soviética após a revolução de 1917. Entretanto, os erros políticos no repasse de verbas e as negociações das importações levaram o estado soviético a perder muito tempo na organização de sua produção local. Apenas com a criação da Sovkino (19241925) e a liberação de um milhão de rublos para a aquisição de película virgem, foi possível o crescimento do número de títulos nacionais. Sobre este ponto, ver: YOUNGBLOOD, Denise, Op. Cit., pp. 53-108. Ver também: THOMPSON, Kristin, "Government Policies and Precipital Necessities in the Soviet Cinema of the 1920's", in LAWTON, Anna (org.), The Red Screen: Politics, Society, Art in Soviet Cinema, London, Routledge, 1992, pp. 19-41.

${ }^{4}$ Tsiteli eshmakunebi, URSS, 1923.

${ }^{5}$ Neobychainye priklyucheniya mestera Vesta v strane bolshevikov, URSS, 1924.

${ }^{6}$ Sobre este assunto, ver: YOUNGBLOOD, Denise, op. cit., pp. 80-83.
} 
Todavia, é importante ressaltar que a história do cinema mudo soviético, embora rica e instigante, ainda é objeto de incompreensão por parte do público acadêmico, em função da má vontade da historiografia da arte de cunho formalista, que geralmente dissocia as conquistas ditas formais de cineastas como Sergei Eisenstein, Vsevolod Pudovkin (1896-1954), Lev Kuleshov (18891970), Dziga Vertov (1896-1954), dentre outros, de sua conexão intrínseca com as questões e debates do processo revolucionário. ${ }^{7}$

As conseqüências nocivas de tal separação induzem a pensar como reciprocamente excludentes os dois terrenos - o histórico-político e o formal. Todo experimento de linguagem no campo da arte soviética, fortemente politizada da década de 1920, incluindo também o trabalho de Eisenstein, estaria, a partir dessa lógica, em xeque ${ }^{8}$ sofrendo a denegação de um dos seus componentes cruciais, vale insistir, o elo genético com a Revolução de Outubro de 1917. Nesse sentido, o reduzido número de estudos referentes aos escritos do cineasta, publicados entre os anos de 1923-27, contribui consideravelmente para a incompreensão do caráter político da obra de Eisenstein, assim como de sua posição dentro do quadro geral das vanguardas artísticas soviéticas. $^{9}$

\footnotetext{
${ }^{7} \mathrm{O}$ artigo "Contra o cinema conceitual", de Luiz Nazário, exemplifica bem este fato. O autor esforça-se, neste texto, para desqualificar enfaticamente a proposta do cinema intelectual de Eisenstein, a partir de uma crítica de caráter semiológico que, em raros momentos, leva em consideração o aspecto histórico e político da obra do diretor. NAZÁRIO, Luiz, As sombras móveis: atualidade do cinema mudo, Belo Horizonte, Editora UFMG, 1999, pp. 89-124. Pode-se citar também, como exemplo, a desqualificação da montagem de Eisenstein por Christian Metz, que argumenta contra a "pretensão" eisensteineana em transformar a linguagem cinematográfica em uma "cine-língua". METZ, Christian, A significação no cinema, São Paulo, Ed. Perspectiva, 1977, pp.31-55.

${ }^{8}$ Sobre este ponto, ver SORENSEN, Janet, "Lef, Eisenstein, and the Politics of Form", in Film Criticism, No. 19, Meadville, Allegheny College, Winter 94/95, pp. 55-74. Ver também BUCHLOCH, Benjamin H. D., "Cold war constructivism", in Serge GUILBAUT (ed.), Reconstructing Modernism/Art in New York, Paris and Montreal 1945-1964, Cambridge, Massachusetts, MIT Press, 1991, pp. 85-110.

${ }^{9}$ Ver STOLLERY, Martin, "Eisenstein, Shub and the gender of the author as producer", in Film History, Vol. 14, No. 1, Bloomington, Indiana University Press, 2002, pp. 87-99.
} 
O trabalho de Eisenstein, como o de outros construtivistas, era marcado por uma forte relação entre teoria e prática. ${ }^{10}$ Seu pensamento sobre o cinema foi dirigido para a criação de um método eficaz de construção fílmica, que considerava o espectador como um campo concreto de intervenção. Para o cineasta, o cinema não faria sentido enquanto forma de arte revolucionária, se não servisse para provocar um diálogo transformador com o público, considerado concretamente, no caso, como o proletariado russo revolucionário.

Ao politizar o debate em sua obra teórica sobre o modo do cinema se relacionar com o espectador, Eisenstein busca compreender, acima de tudo, como a sintaxe do cinema, aliada a técnicas oriundas do teatro, da pintura e da literatura, torna-se produtora de significados. Sua primeira formulação teórica sobre o teatro, a teoria da montagem de atrações ${ }^{11}$ - posteriormente transplantada para o cinema -, apresenta-se ligada ao propósito de transformação da sociedade e pensa assim a obra de arte sob a noção construtivista de encomenda social.

Esta noção, proposta segundo formulação do dramaturgo e escritor Sergei Tret'iakov (1892-1937) - amigo e colaborador de Eisenstein no período em que trabalhou como diretor de teatro no Proletkul't -, constitui conceito

\footnotetext{
${ }^{10}$ Ver ALBERA, François, Eisenstein e o Construtivismo Russo, Op. Cit., Ver também TARABOUKINE, Nikolaï, "Du chevalet à la machine" in idem, Le Dernier Tableau/ "Du chevalet à la machine"; "Pour une théorie de la peinture"/ écrits sur l'art et l'historie de l'art à l'époque du construtivisme russe", apr. A. B. Nakov, trad. M. Pétris e A. B. Nakov, Paris, Champ Libre, 1980. Ver também LODDER, Christina, Russian Constructivism, New Haven, Yale University Press, 1990.

${ }^{11}$ A primeira formulação desta teoria foi publicada em forma de manifesto na revista LEF, em 1923. EISENSTEIN, Sergei, TAYLOR, Richard (Ed. e trad.), S. M. Eizenshtein Writings, 192234, London, BFI Publishing, 1987, pp 33-38. Tret'iakov, no ano seguinte, analisa a montagem de atrações, ressaltando algumas das características que a inserem dentro da perspectiva da "encomenda social", em artigo publicado no primeiro número do jornal Oktiabr' mysli. TRET'IAKOV, Sergei, "The Theater of Attractions", in OCTOBER 118, Fall 2006, Cambridge, MA, MIT Press, PP. 19-26.
} 
decisivo para a compreensão do trabalho artístico do cineasta (tanto no teatro quanto no cinema) e da vanguarda construtivista russa.

Nesse sentido, é possível supor que o estágio inicial da obra cinematográfica de Eisenstein estabelecia um forte diálogo com os primeiros construtivistas, ligados a institutos e oficinas de arte, subordinados ao Narkompros $^{12}$, como o INKhUK ${ }^{13}$, a Proletkul't ${ }^{14}$ e os VKhUTEMAS ${ }^{15}$ - artistas que tratavam a prática artística a partir das distinções entre material, textura, forma e finalidade - bem como os teóricos produtivistas (Sergei Tret'iakov e Boris Arvatov, principalmente), pensadores que consideravam a figura do artista não mais como criador inspirado, mas como trabalhador que punha seu conhecimento a serviço da construção de uma nova sociedade. Tais concepções artísticas (primeiro do construtivismo e, depois, radicalizadas pelo produtivismo) extraíam e pesquisavam elementos da crítica social marxista, da engenharia e da prática industrial na tentativa de descobrir fundamentos para uma atividade que pudesse superar a arte burguesa tradicional, objetivando reintegrar assim a figura do artista à dinâmica do cotidiano e da história social.

A Greve intervem diretamente no novo contexto da luta de classes instalado na URSS, em função da nova dinâmica de mercado trazida pela NEP. Produzido em colaboração com o primeiro teatro operário da Proletkult, A

\footnotetext{
12 Abreviação em russo para Comissariado para o esclarecimento do povo (Народный комиссариат просвещения), órgão estatal soviético equivalente a um ministério da educação e cultura. Ver LODDER, Christina, Russian Constructivism, New Haven, Yale University Press, 1990.

${ }_{13}^{13}$ Instituto de Cultura Artística, Moscou, 1921-1924. Ver idem.

${ }^{14}$ Proletkul't é a abreviação em russo para Proletarskaya Kultura (пролетарская культура): Cultura Proletária. Tratava-se de um movimento cultural que tinha como objetivo o estabelecimento de uma cultura revolucionária e popular, que negasse a arte e a estética burguesa. Perdurou entre os anos de 1917 e 1925. Ver GORDON, Mel, "Eisenstein's Later Work at the Proletkult", in The Drama Review: TDR, Vol. 22, No. 3, Cambridge, MA, The MIT Press, 1978, pp. 107-112.

${ }^{15}$ Oficinas Técnico-Artísticas Avançadas, Moscou, 1920-1930. Ver MIGUEL, Jair Diniz, Arte, Ensino, Utopia e Revolução: Os Ateliês Artísticos Vkhutemas/Vkhutein (Rússia/URSS, 19201930), Tese de Doutorado, São Paulo, Universidade de São Paulo, 2006.
} 
Greve é uma obra de agitação política que volta à questão da organização operária independente (posta historicamente pelo debate político em torno da Revolução de 1905 e seus desdobramentos). No momento de A Greve (19245), o novo Estado soviético, que se cristaliza após o fim da guerra civil, pauta a construção do socialismo por meio da associação "do poder soviético e da organização soviética da direção com as últimas conquistas do capitalismo". ${ }^{16}$ 


\section{PRIMEIRO CAPÍ'TULO:}

\section{A Greve: uma rememoração da questão da organização política do proletariado no contexto da NEP}

\section{I: Introdução}

Até o final do século XIX, a Rússia ainda era um país com uma estrutura social extremamente atrasada em relação aos países do oeste europeu, como a Inglaterra. Tratava-se de um país governado por uma dinastia de czares, com plenos poderes sobre o judiciário, a administração pública e o exército, além de

primazias no Santo Sínodo, colegiado máximo da Igreja Ortodoxa russa. A máquina administrativa czarista era composta principalmente pela nobreza, detentora de grandes extensões de terra, cultivadas pela grande maioria da população russa: os servos.

Após a derrota russa na Guerra da Criméia (1853-1856) (frente à aliança formada por Grã-Bretanha, França e o Piemonte), o Czar Alexander II, que iniciara seu reinado em 1855, levou a cabo uma série de reformas para modernizar o império, tendo em vista que, para o líder autocrata, uma das principais causas da derrota militar fora o atraso sócio-econômico de seu país. De acordo com o Edital de Emancipação de 03.03.1861 - documento no qual Alexandre II promulgou uma de suas principais reformas - o governo garantia liberdade plena aos servos, além de uma parcela determinada das terras pertencentes à nobreza, para que a recém-liberta classe pudesse garantir seu 
sustento. Ademais, o Edital de Emancipação estabelecia indenizações para a nobreza e obrigava o campesinato a pagar uma soma anual, que assegurava seu direito à posse da terra. As parcelas anuais pagas pelos camponeses não garantiam o direito à plena propriedade: somente após vinte anos a terra lhes pertenceria de fato. Nesse ínterim, as propriedades seriam administradas por pequenos órgãos cooperativos alocados nas aldeias, que cederiam aos camponeses o uso da terra, a fim de que obtivessem condições para pagar as parcelas anuais ao governo.

Ocorre que tal "reforma agrária" provou ser extremamente insatisfatória para o campesinato. As quotas de terras disponíveis nas vilas para cada agricultor eram insuficientes para manter uma família acima do nível de pobreza, já que, a maioria das terras expropriadas pelo governo eram pouco produtivas (no processo de expropriação, o nobre poderia escolher qual parcela de sua propriedade seria doada ao Estado). A soma paga anualmente ao governo, relativa ao direito de propriedade rural do camponês liberto, na maioria das vezes, era mais alta do que os encargos que os servos outrora pagavam à nobreza. Na medida em que a população rural crescia, a parcela de terras individuais de cada família camponesa diminuía. O Edital de Emancipação não estabelecera porções fixas de terra, apenas uma divisão simples entre as propriedades que foram estipuladas para cada aldeia.

Antes das reformas do reinado de Alexandre II (1855-1881), a administração pública nas áreas rurais era dominada pela nobreza. A reforma de 1864 criou as "dumas" (parlamentos) nas cidades e as "assembléias provinciais no campo" (zemstva) - órgãos compostos por representantes locais 
eleitos (oriundos de qualquer classe social), que atuavam no foro das assembléias distritais. Tratava-se de um sistema administrativo que, apesar de conceder primazia à nobreza (nos zemstvo dos distritos rurais) e aos mercadores e profissionais liberais (médicos, advogados, etc.) (nas dumas das cidades) contriuiu para diminuir as contradições sociais no campo, conferindo mais direitos políticos para as classes trabalhadoras. ${ }^{17}$ Tais assembléias eram encarregadas da administração pública local e desempenhavam as mais diversas tarefas: organização da educação e da saúde pública, a manutenção de estradas e pontes, o fomento à atividade manufatureira e a eleição dos juízes de paz.

De fato, a implementação do sistema das dumas e dos zemstvo tinha por objetivo dar cabo de um sistema sócio-político que ainda era, praticamente, feudal e preparar o país para um processo de modernização que visava à instauração efetiva do capitalismo. A década de 1890 foi marcada pelo grande avanço na industrialização da Rússia (que começara inicialmente com as reformas do reinado de Alexandre II), e fora financiada por meio de empréstimos franceses (após assinatura de um tratado com a França em 1893). Com capital em mãos, o estado czarista passou a conduzir o processo e a fomentar a atividade industrial, oferecendo empréstimos e auxílio gerencial à iniciativa privada. Grandes pólos urbanos e industriais se desenvolveram rapidamente e o proletariado (operariado do setor metalúrgico e têxtil, principalmente) se tornou uma classe social que progressivamente foi ganhando importância na sociedade russa. Em 1914, o número de

\footnotetext{
${ }^{17}$ Cf. ANDRLE, Vladmir, A social History of Twentieth Century Russia, London, Edward Arnold Ed., 1994, pp.1-2.
} 
trabalhadores nos centros urbanos atingira cerca de dois milhões, e em 1917, três milhões.

Embora a Rússia em 1914 ocupasse o quinto lugar entre as nações industriais do mundo, em termos de produção industrial, seu desempenho no setor não se traduzia em condições de trabalho equivalentes às de outras potências industriais européias. Os operários russos recebiam aproximadamente trinta por cento do salário trabalhadores britânicos. As longas jornadas de trabalho (em média, quinze horas por dia), a ausência de instalações sanitárias apropriadas e a falta de dispositivos mínimos de segurança faziam com que fosse insuportável o cotidiano do operariado fabril russo. Embora o governo czarista tivesse aprovado, a partir da década 1880, um conjunto de leis que proibiam o emprego de menores de doze anos, o trabalho noturno para as mulheres e tivesse criado um sistema de inspeção pública do trabalho (encarregado de policiar eventuais abusos nos contratos de trabalho), tais medidas não contribuíram para melhorar significativamente as condições tão precárias dos trabalhadores (uma vez que a fiscalização das leis trabalhistas não era efetiva). ${ }^{18}$ As relações entre empregados e empregadores no contexto social russo eram dramáticas, haja vista que a luta por melhores condições de trabalho - o direito à greve e o direito à organização sindical eram considerados ilegais pela lei czarista. ${ }^{19}$ As propostas de negociações pacíficas por parte de grupos de trabalhadores geralmente acarretavam demissões e penalizações em massa, fator que desestimulava a mobilização coletiva.

\footnotetext{
${ }^{18}$ Cf. ANDRLE, Vladmir, A social History of Twentieth Century Russia, London, Edward Arnold Ed., 1994, pp.100-101.

${ }^{19}$ Idem, pp. 105.
} 


\section{II: 1905}

Entre os anos de 1902 e 1903, o governo do czar Nicolau II (1894-1917) enfrentava uma série de desafios à estabilidade social e política russa em escala inédita ante o que se conhecera no século XIX. A insatisfação do povo fora se espalhando da Ucrânia até o Volga, greves proletárias, principalmente na parte meridional do país, paralisaram amplos setores da indústria. $\mathrm{O}$ panorama social de agitação e revolta generalizadas - fruto das péssimas condições de vida e de trabalho nas cidades e no campo - fomentou a explosão de diversas rebeliões isoladas contra as forças econômicas dominantes (greves nas cidades e invasões de terras no campo). Tal cenário propiciou também para o desenvolvimento de uma oposição política ao regime czarismo mais organizada, que se cristalizou sob a forma de partidos políticos clandestinos de orientação revolucionária e social-democratas, além de vários grupos menores de inspiração liberal. Todavia, as ações isoladas de tais focos de resistência política não conseguiram quaisquer êxitos significativos na organização das massas trabalhadoras antes da Revolução de $1905 .^{20}$

Entre janeiro e outubro de 1905, diversos setores da sociedade se organizaram num ataque espontâneo e não coordenado ao governo czarista. 0 movimento foi organizado por trabalhadores envolvidos e também por entidades de profissionais liberais. ${ }^{21}$ Suas exigências eram tanto políticas (a queda do absolutismo) como econômicas (melhores condições de trabalho, salários mais dignos, etc.). Tal movimento fora acompanhado por ataques

\footnotetext{
${ }^{20}$ Cf. ANDRLE, Vladmir, A social History of Twentieth Century Russia, London, Edward Arnold Ed., 1994, pp.107-108.

${ }^{21}$ Cf. ANDRLE, Vladmir, Op. Cit., p. 108.
} 
camponeses às propriedades da nobreza, insurgências que ocorreram desde a primavera de 1903 até meados 1907 e também por motins no exército e na marinha, em diversos destacamentos mobilizados na guerra contra o Japão. ${ }^{22}$

No interior de uma das greves dos proletários, numa cidade ao norte de Moscou, Ivanovo-Voznesensk, foi criada pelos operários, em maio de 1905, uma forma de organização bastante original, então denominada Soviet (conselho). Tratava-sede um organização constituída por representantes (delegados) dos operários, eleitos nas próprias fábricas, sem mandato fixo, que poderia ser revogado a qualquer momento. ${ }^{23}$ Como a cidade era pequena, a fim de não chamar atenção, os delegados deste primeiro Soviet se reuniam nos bosques e campos vizinhos e sua estrutura chegou a contar com 151 membros eleitos, durando 72 dias até que se autodissolveu. A social-democracia russa pouco influíra no processo. Por se tratar de uma iniciativa local, seus representantes não esperavam que tal experiência fosse ter maior ressonância. Ocorre que, a forma "Soviete" se espalhou. ${ }^{24}$ Até o fim de 1905, os Sovietes, "parlamentos plebeus" por excelência, se formaram em dezenas de grandes e pequenas cidades. $O$ mais importante deles foi constituído em São Petersburgo, embora não tenha durado mais de dois meses e tenha sido dissolvido pela polícia, que prendeu todas as lideranças numa rápida operação.

A resposta do governo czarista aos movimentos grevistas veio por meio de uma série de concessões políticas, em Fevereiro de 1905. Todavia, fora

${ }^{22}$ Ver TROTSKY, Leon, 1905, Buenos Aires, Centro de Estudios, Investigaciones y Publicaciones "Leon Trotsky", 2006, pp. 165-171. Ver também MILIOUKOV, Paul, Histoire de Russe, Tome III, Réforme, Réaction, Révolutions (1855-1932), Paris, L'Institut d'Études slaves de L'Université de Paris, 1933, pp. 1070-1085.

${ }^{23}$ Cf. DEMOCHKIN, Nikolai N., "El nascimento de los primeiros sovietes em 1905", in TROTSKY, Leon, 1905, Op. Cit., pp. 384-386.

${ }^{24}$ Ver ANDRLE, Vladmir, A social History of Twentieth Century Russia, London, Edward Arnold Ed., 1994, pp.110-111. Ver também Cf. DEMOCHKIN, Nikolai N., Art. Cit., pp. 381-387. 
somente em outubro, que o czar, aconselhado por seu ministro de assuntos internos (o mesmo que arquitetara a Guerra contra o Japão), apresentou um pacote de reformas suficientemente amplas, aptas a esfriar o ânimo dos insurgentes e dividir as organizações políticas de oposição. ${ }^{25}$ Tal manifesto imperial, datado de 17.10.1905, prometia liberdades civis amplas e a convocação de uma assembléia nacional representativa, uma Duma constitucional, que teria poderes legislativos e autonomia política para agir de acordo com os interesses dos trabalhadores. Tais reformas foram suficientes para satisfazer a maioria dos liberais e até mesmo alguns dos socialistas se mostraram dispostos a dar crédito às reformas prometidas. Contudo, os revolucionários não se deram por satisfeitos e se lançaram numa campanha em prol de uma república democrática, a ser constituída mediante uma assembléia constituinte, além de reformas de caráter social, tais como a garantia legal para as oito horas de trabalho diária e a expropriação dos latifúndios da nobreza. Os radicais revolucionários organizaram uma insurreição de trabalhadores, em dezembro de 1905, no distrito industrial de Moscou, que foi brutalmente esmagada pelas tropas do governo. Esse episódio foi o mais violento do ano ficou caracterizado consagrar-se como uma mostra da estratégia de aniquilação da Revolução: uma combinação de repressão brutal e reformismo vazio.

É possível afirmar que o manifesto czarista de outubro pôs um fim ao movimento de greves que assolou a Rússia e que ficou conhecido como a Revolução de 1905. Todavia, as concessões feitas pelo czar, presentes em seu manifesto, não foram suficientes para diminuir o ímpeto revolucionário, que

\footnotetext{
${ }^{25}$ Ver KOCHAN, Lionel, Origens da Revolução Russa, Rio de Janeiro, Zahar Editores, 1968, pp. 79-81.
} 
estava disseminado nos proletários que participaram ativamente dos Sovietes, nas seções dos trabalhadores, nos camponeses que se rebelaram, e no contingente desmobilizado das forças armadas, após o fim da guerra contra o Japão. Tendo em vista o resultado da Revolução de 1905, é possível afirmar que pouca coisa mudou. A autocracia sobreviveu e sua estrutura de poder permaneceu praticamente inalterada, exceto pela existência da Duma (que após 1905, teve uma força política bem pouco efetiva à figura do czar). As mudanças sociais também foram mínimas. O principal conjunto de medidas reformistas (aplicadas em 1906), relativas a questões de caráter sócioeconômico no campo, visava à dissolução das comunas camponesas, um dos principais focos de resistência política à autocracia no campo. Tais medidas poderiam ser consideradas na época como uma de atitude contrarevolucionária exemplar, tendo em vista que as reformas introduzidas correspondiam mais aos interesses do governo do que as demandas dos camponeses. 


\title{
III: 1917: o primeiro governo operário e camponês
}

\begin{abstract}
O fato de ter o proletariado chegado ao poder, pela primeira vez, num país tão atrasado, como a Rússia, só à primeira vista pode parecer misterioso. $\mathrm{Na}$ realidade, resulta de uma lógica rigorosa. Podia-se prever. E previu-se. Mais ainda: diante dessa perspectiva, os revolucionários marxistas elaboraram a sua estratégia muito antes dos acontecimentos decisivos. A primeira explicação e a mais geral: a Rússia é um país atrasado. Mas, também, a Rússia não é mais que uma parte da economia mundial, um elemento do sistema capitalista mundial. E Lênin resolveu o enigma da revolução russa com a seguinte fórmula lapidar: a cadeia rompeu-se pelo elo mais fraco. Uma situação clara: a grande guerra, produto das contradições do imperialismo mundial, arrastou em seu torvelinho países que se achavam em diferentes etapas de desenvolvimento e impôs a todos as mesmas exigências. Resulta, pois, que os encargos da guerra se tornariam mais insuportáveis, particularmente, para os países mais atrasados. A Rússia foi o primeiro que se viu obrigado a ceder terreno. Mas, para sair da guerra, o povo precisava abater as classes dominantes. Assim foi como a cadeia se quebrou. ${ }^{26}$
\end{abstract}

Grosso modo, até 1914 a Rússia podia ser caracterizada como um país continental que enfrentava sérios problemas sociais devido, por um lado, ao empobrecimento da população rural (decorrente das altas taxas aplicadas pelo governo, relativas ao uso ou à aquisição de terras cultiváveis), e, por outro lado, ao crescimento constante da população de trabalhadores industriais. Embora a iniciativa capitalista industrial russa tivesse proporcionado grandes avanços na primeira década do séc. XX (ampliação do comércio exterior e construção de uma rede de infra-estrutura mais moderna), o desenvolvimento do país fora dificultado pela ausência de dinâmica no mercado interno. Excluindo os grandes latifundiários, a maioria da população rural (camponeses e trabalhadores alocados nas regiões periféricas, que correspondiam a

\footnotetext{
${ }^{26}$ TROTSKY, Leon, "Die russische Revolution: Kopenhagener Rede". Conferência pronunciada em Copenhagen, em novembro de 1932. Texto original em alemão disponível no formato hipertexto em http://www.marxists.org/deutsch/archiv/trotzki/1932/11/koprede.htm. Ver também versão em espanhol TROTSKY, LEON, Lecciones De Octubre ¿Que Fue La Revolucion Rusa?, Buenos Aires, Editorial El Yunque, 1975, pp. 79-106.
} 
praticamente $90 \%$ da população russa) era demasiadamente pobre para consumir mercadorias industrializadas com regularidade. Entretanto, não deixa de ter interesse ressaltar que, na contramão do panorama social da época, a atividade industrial e a exportação de grãos, na década de 1900 e na primeira metade de 1910, consistiam numa atividade lucrativa para a Rússia, do ponto de vista econômico. O fato era que a manutenção dos lucros no capitalismo russo se constituíra fundamentalmente a partir de medidas tais como demissões, longas jornadas de trabalho, diminuição dos salários e aumento dos preços para o mercado interno. Ora, este tipo de atitude gerencial (tanto no campo quanto nas cidades), grosso modo, forneceu "material" de sobra para alimentar a insatisfação da classe trabalhadora, estimulando sua atividade sindical e sua organização política.

O Partido Social-Democrata Russo, uma das principais forças políticas que atuavam na Duma, estava dividido em duas facções que acabaram por formar dois partidos diferentes, e posteriormente desempenhariam papéis de destaque nos eventos que configuraram a Revolução de 1917. Os Меньшевики (Menchevique, palavra russa que designa "minoria") e os Большевики (Bolchevique, a "maioria") discordavam sobre a maneira pela qual deveria ocorrer o processo de transição, na Rússia, da autocracia para o socialismo. Segundo a perspectiva do menchevismo, era essencial que a Rússia passasse pelo estágio do desenvolvimento de práticas capitalistas e do governo democrático. Em contrapartida, os bolcheviques, de postura mais radical, consideravam fundamental que, a partir de um processo de luta contra o estado autocrático, se desse a organização das classes trabalhadoras. A partir da experiência da Revolução de 1905, os bolcheviques acreditavam que 
a conquista do poder na Rússia poderia preceder e inspirar a luta revolucionária nos países industrialmente mais avançados da Europa Ocidental. Muito embora bolcheviques e mencheviques tivessem posturas políticas divergentes, ambos atuavam estrategicamente na Duma, disputando as cadeiras do parlamento e atacando a autocracia czarista, sempre a partir de proposições que visavam à completa reforma política do país, embora mantivessem princípios distintos.

Quando a Rússia entrou guerra em 1914, os representantes bolcheviques se opuseram veementemente, votando contra o remanejamento de recursos do Estado para o setor militar. Tal postura política mostrou que o partido bolchevique já antevira que o nível de desenvolvimento econômico e industrial russo não permitiria manter o país em um conflito contra uma potência como a Alemanha. Embora o agravamento da situação sócioeconômica da Rússia pudesse se constituir, de um ponto de vista estratégico, como um fator positivo na luta contra o czarismo, a adoção de uma postura política de oposição à guerra poderia contribuir para fortalecer a influência bolchevique sobre a classe trabalhadora.

Após sucessivos revezes no campo de batalha, a Rússia chegou a um ponto no qual a sua participação na guerra se tornara praticamente insustentável. As dificuldades impostas à população civil (a escassez de alimentos e os preços elevados de quase todos os itens de subsistência básica) e às tropas mobilizadas nos fronts (transportes inadequados, armas obsoletas, etc.), aliadas a escândalos de corrupção e ineficiência da máquina estatal, adicionaram mais elementos e criaram condições de revolta. Greves - 
que reivindicavam não apenas melhores salários, mas também a retirada do país da guerra - alastraram-se nas principais cidades. Motins e deserções em massa se multiplicavam nas frentes de batalha russas. $O$ contingente desmobilizado, oriundo do processo de desgaste do exército, se somou à massa de civis descontentes com o governo autocrático.

Diante do agravamento do panorama social, em março de 1917 o czar ordenou a dissolução da Duma. Ocorre que tal medida se mostrara ineficaz na medida em que, efetivamente, a maioria do parlamento insistira na continuação de suas atividades. Após a intensificação das manifestações do exército e da violência e do caos que dominavam as principais cidades, o czar, por fim, abdicou em 15 de março de 1917, em meio ao crescente caos que se desenhada em Petersburgo. Um governo provisório foi rapidamente formado na Duma por representantes políticos de diversos partidos, juntamente com o ministro da Justiça Kerensky (1881-1970). Simultaneamente, conselhos de trabalhadores, camponeses e soldados estavam sendo formados nos principais centros urbanos. O modelo de autogestão operária dos Sovietes, resgatado da revolução de1905, novamente voltava à cena política revolucionária.

Controlados em sua maioria por delegados de postura hostil em relação às posições políticas bolcheviques, os Sovietes inicialmente declararam amplo apoio ao Governo Provisório liderado por Kerensky, Ministro da Justiça que, no ínterim da formação do governo, tornara-se vice-presidente do Congresso dos Sovietes. No plano político, a figura de Kerensky se constituiu como no elo entre a o Congresso dos Sovietes e o Comitê da Duma. O apoio inicial dos Sovietes fora de importância crucial para a consolidação do Governo 
Provisório, engajado no combate às manobras bolcheviques, que visavam desacreditar as políticas "reacionárias" praticadas pela direção do Comitê da Duma (por exemplo, a manutenção da participação da Rússia na guerra).

Em junho de 1917, a "minoria" bolchevique organizou um ato de agitação (uma parada armada) de soldados e trabalhadores. Tratava-se de uma manifestação contra o Governo Provisório, na qual slogans "Abaixo o governo capitalista! Abaixo a guerra! Todo o Poder aos Sovietes!" foram o mote que conclamava as classes trabalhadoras e os soldados a se voltarem contra um governo que estava marchava na contra mão dos interesses da massa que destituíra o Czar em fevereiro. Durante os meses seguintes, o Partido Bolchevique, apesar da crescente perseguição política empreendida pelo governo de Kerenski, continuava seu trabalho de agitação e propaganda ativa em favor da paz, da expropriação dos latifúndios e da convocação de uma assembléia nacional constituinte, eleita democraticamente.

No início de setembro o partido Bolchevique logrou eleger um presidente no Soviete Krondstadt. Após esta primeira vitória, em primeiro de outubro, os bolcheviques já ocupavam a maioria das cadeiras do Soviete de Moscou e Trotsky (1879-1940), uma das figuras de destaque do partido bolchevique, assumiu a presidência do Soviete de Petrogrado em oito de outubro. Seis dias depois, os deputados de Petrogrado aprovaram a resolução que exigia a transferência de todo o poder político aos Sovietes, bem como o fim da guerra, e, em vinte e dois de outubro, formou-se um Comitê Militar Revolucionário, cujo objetivo era centralizar o comando das Guardas Vermelhas (tropas formadas por soldados e operários armados, encarregada do policiamento dos centros 
urbanos). Também no mês de outubro teve início em toda a Rússia uma onda

de invasões e expropriações de latifúndios, comandadas por lideranças

camponesas locais. Diante do panorama que se desenhava, que, em 23 de

outubro, o Comitê Central do Partido Bolchevique aceita a resolução

apresentada por Lênin em favor da insurreição armada:

O momento crítico estava agora perto, sendo fixado pela decisão de desferir o golpe antes do Segundo Congresso Panrusso de Soviete se reunir, na tarde de sete de novembro [vinte e cinco de outubro de 1917, de acordo com o calendário gregoriano]. $\mathrm{Na}$ véspera do dia designado, o comitê central [do partido bolchevique] reuniu-se para dar os últimos retoques a alguns preparativos práticos [...] Trotsky pediu que membros do comitê central fossem agregados ao comitê militar revolucionário do Soviete de Petrogrado, para cuidarem das comunicações postais, telegráficas e ferroviárias e para vigiarem - Governo Provisório. [...] Ganhava forma no comitê do partido uma administração embrionária. Na manhãzinha [de sete de novembro] de 1917, as forças bolcheviques passaram à ação. Os pontos-chave da cidade [de Petrogrado] foram ocupados; os membros do Governo Provisório foram aprisionados ou fugira; à tarde Lênin anunciou a uma reunião do Soviete de Petrogrado o triunfo da "revolução dos operários e camponeses" ${ }^{27}$; ao cair da noite, o Segundo Congresso Panrusso de Sovietes Proclamou a transferência de todo o poder na Rússia para os Sovietes de deputados operários, soldados e camponeses. Ao fim da tarde de oito de novembro de 1917, a segunda e última reunião do congresso adotou os decretos sobre a paz e a terra e aprovou a composição do Conselho de Comissários do Povo, conhecido popularmente como Sovnarkom - o primeiro governo operário e Camponês. ${ }^{28}$

\footnotetext{
${ }^{27}$ Lenin, Sochineniya, XXII, 4-5, apud CARR, E. H., The Bolshevik Revolution, Vol. 1, London, W. W. Norton \& Company, 1985, p. 119.

${ }^{28}$ CARR, E. H., Op. Cit., Loc. Cit.
} 


\section{IV: NEP: "aumentar a produtividade do trabalho e socializar a produção na prática"}

A vitória da Revolução de Outubro mostrou, na contramão do pensamento social democrata europeu, que "em determinadas condições, os países atrasados poderiam chegar à ditadura do proletariado antes que os avançados e, no entanto, mais tarde que estes ao socialismo". Todavia, segundo a perspectiva bolchevique, para que a revolução socialista se consolidasse, seria necessário que o movimento revolucionário ganhasse contornos internacionais. No final do ano de 1920, encerrada a guerra civil que se instaurou poucos meses após a revolução de outubro de 1917, os bolcheviques se viram no comando de um país isolado, econômica e politicamente, em relação ao resto da Europa ocidental. Os revolucionários russos apostavam no êxito dos movimentos revolucionários que estavam em curso na Europa, principalmente na Alemanha, país que detinha um grau avançado de desenvolvimento das forças produtivas (sobretudo no âmbito tecnológico) e uma classe proletária razoavelmente instruída e qualificada. A vitória de uma revolução na Alemanha proporcionaria um parceiro estratégico para a Rússia revolucionária, contribuindo na tarefa de transição para o socialismo. Contudo, a "revolução européia" não vingou e os sistemas políticos que sustentavam o capitalismo na Europa ocidental davam mostras de sua solidez.

Governada por um partido revolucionário que procurava abrir terreno rumo à transição ao socialismo, a Rússia se viu cercada por um mundo 
capitalista hostil. A partir desse contexto, em 1921, o III Congresso da Internacional Comunista tirou resoluções que tinham como escopo a superação dos problemas relativos à organização do movimento revolucionário europeu (sindicatos, facções, partidos comunistas), a fim de criar e preparar as condições necessárias para a revolução. A esse respeito dessa empreitada, Lênin afirmava: "A república socialista pode subsistir dentro de um cerco capitalista, mas certamente não por muito tempo".

Com efeito, as conquistas históricas da revolução estavam em risco. A política adotada durante os anos da guerra civil, o "comunismo de guerra" (1918-1920), consumira boa parcela das forças produtivas do país, já então bastante desgastado por sua participação na Primeira Guerra Mundial. A Rússia, naquele momento histórico, era a expressão de uma contradição latente. Tratava-se, por um lado, de um país que possuía o regime político mais avançado do mundo (a ditadura do proletariado), mas que, por outro, ainda não havia conseguido estabelecer uma base econômica interna sólida - elemento imprescindível para a consolidação do estado operário. A escassez de alimentos abatia parcela considerável da população e o abastecimento dos centros urbanos, por meio da requisição da produção rural (uma das principais medidas econômicas do "comunismo de guerra") levara ao crescimento da insatisfação da população rural para com o governo bolchevique. Em 1921, a desmobilização do Exército Vermelho (contingente formado pelo governo bolchevique, composto por oficiais do governo czarista que se aliaram à causa da Revolução de 1917 e por operários e camponeses convocados) contribuiu para o agravamento do contexto sócio-econômico russo. O aumento significativo da mão de obra (os soldados desmobilizados) não foi 
acompanhado por um crescimento dos postos de trabalho. Conseqüentemente, houve um aumento acentuado da taxa de desemprego e êxodo dos centros urbanos.

No meio deste turbilhão, em março de 1921, o X Congresso do Partido Comunista (bolchevique) da Rússia deliberou o fim do sistema de contingenciamento - um dos principais fundamentos da política econômica do Comunismo de Guerra. A partir de então, a arrecadação de impostos seria efetuada em espécie e os excedentes da produção agrícola e industrial poderiam ser livremente comercializados por iniciativa camponesa e das fábricas controladas pelos operários. Tais medidas estabeleceram o marco inicial do processo de transição da política do Comunismo de Guerra para a Nova Política Econômica (Новая экономическая политика, conhecida largamente como NEP). Concebida por Lênin como uma "retirada forçada" rumo ao mercado, a fim de obter um o aumento significativo da produção, a NEP tinha como objetivo principal estimular o campesinato a desenvolver um sistema eficiente de distribuição de alimentos e o fortalecimento de um mercado consumidor interno.

Poucos meses depois, o Sovnarkom (Совет народных коммиссаров), о Conselho de Comissários do Povo, instituído logo após a Revolução de Outubro, lançou um pacote de medidas que visava ao desenvolvimento de um sistema de cooperativas rurais, cujo objetivo era dar um novo impulso à economia camponesa. O plano de cooperação elaborado por Lênin se constituía, no âmbito prático, num estímulo à gestão coletiva dos assuntos econômicos no campo. Essa medida fora elaborada como uma forma de 
fomento ao hábito da venda, da aquisição de crédito e etc., de modo a preparar o campesinato para a condução conjunta da produção na советское хозяйство (fazenda soviética). Tal plano era também uma estratégia que visava incentivar às práticas de organização social capazes de preparar a população rural menos instruída para a transição ao socialismo. Contudo, apesar da preocupação em estimular a auto-gestão coletiva no campo, as demais medidas econômicas que constituíram a NEP tiveram como resultado o aumento dos componentes capitalistas no âmbito econômico soviético. No final do ano de 1921, a presença de empreendimentos de iniciativa privada no setor industrial e comercial já era uma realidade no contexto russo. No meio rural, uma parcela do campesinato que não estava ligada aos kolkhoze (fazendas coletivas) enriqueceraem conseqüência do desenvolvimento das relações monetário-mercantís no campo.

Tendo em vista o contexto sócio-econômico da Rússia após a Guerra Civil e a derrota dos movimentos revolucionários na Europa ocidental, Lênin não considerou possível, naquele momento, tentar suprimir totalmente 0 capitalismo. A única política viável seria então a utilização de práticas capitalistas com o objetivo de elevar as forças produtivas. Com efeito, ao permitir, a partir de 1921, o intercâmbio de capital estrangeiro e a produção privada - a possibilidade da acumulação de capital -, ainda que limitada, a direção do Estado soviético concedera à burguesia russa e ao grande capital europeu um papel importante no processo de reconstrução do país. Entretanto, a figura do Estado nesse processo era ainda preponderante, na medida em que mantinha os principais recursos da indústria e dos transportes, assim como o monopólio do comércio exterior. 
Lênin não descartava o fato de que a aplicação de tal política exigiria o enfrentamento de uma série de dificuldades e contradições inevitáveis. Desde 1917, Lênin já propusera medidas concernentes à nacionalização e fusão dos bancos e dos monopólios, a abolição do sigilo comercial e a organização obrigatória da população em cooperativas de consumo. Essas propostas, contudo, não eram estranhas aos Estados imperialistas, em muitos dos quais já vigorava um capitalismo monopolista de Estado, cuja centralidade se tornara ainda mais acentuada no momento da mobilização total para a guerra. Contudo, ressaltava Lênin, em $A$ Catástrofe Iminente e Como Combatê-la (artigo distribuído em forma de panfleto, logo após a Revolução de Outubro), "a dominação da burguesia é incompatível com uma verdadeira democracia, autenticamente revolucionária." ${ }^{29}$ Nesse sentido, Lênin cogitava, de imediato, a criação de um Estado democrático-revolucionário, que fosse capaz de introduzir o capitalismo de Estado, como meio para consolidar a Revolução e também para o desenvolvimento das condições sócio-econômicas necessárias à transição para o socialismo. A Rússia não possuía ainda uma base material comparável à dos estados capitalistas burguês. Todavia, ela poderia estabelecer uma forma de economia similar, organizada e a dirigida pela classe operária. Na perspectiva de Lênin, "o capitalismo monopolista de Estado, num Estado verdadeiramente democrático, revolucionário, representaria, inevitavelmente, infalivelmente, um passo, e mais do que um passo para 0 socialismo [... visto que] o socialismo nada mais é do que o monopólio

\footnotetext{
${ }^{29}$ LENIN, V. I., "The Impending Catastrophe and How to Combat It", in Lenin Collected Works, Progress Publishers, 1977, Moscow, Volume 25, p. 360.
} 
capitalista de Estado posto a serviço de todo o povo e que, por isso, deixou de ser monopólio capitalista". 30

A NEP, no limiar de sua implementação (entre 1920-1921), se constituiu na alavanca para a reconstituição e para o desenvolvimento da economia nacional, bem como para o fortalecimento dos componentes socialistas. Entretanto, ela também proporcionou, nos primeiros anos após a revolução, a irrupção de tendências capitalistas que se manifestaram no plano social (o estimulo ao consumo individual). Por isso, a NEP não significou o fim da luta de classes no país, mas sua continuação sob novas formas. O início da estabilidade econômica, decorrente da adoção da NEP, propiciou o estímulo de práticas produtivas que visavam preparar o campesinato e o operariado russos para a futura aplicação do processo de transição para o socialismo. A base da administração das indústrias, por exemplo, foram os consórcios de produção — associações com auto-gestão financeira - e os sindicatos, que se ocuparam da organização planificada da venda da produção dos consórcios. Implantou-se e consolidou-se o princípio de comando único que contava com ampla participação dos trabalhadores e de suas organizações sociais (sindicatos, etc.) na administração da indústria. O estímulo ao trabalho e à administração coletiva se constitui como um ponto fundamental, uma vez que, para Lênin,

[...] a vitória da revolução socialista será assegurada somente se o proletariado e os camponeses pobres desenvolverem suficiente consciência de classe, devoção aos princípios, abnegação e perseverança. Ao criar um novo tipo de Estado, o Estado soviético, que dá as massas trabalhadoras e oprimidas a possibilidade de participar ativamente na construção independente de uma nova sociedade, resolvemos só uma pequena parte deste difícil problema. A dificuldade principal está no terreno econômico: isto é, em introduzir um registro e um controle mais estrito e geral da produção e da

${ }^{30}$ Idem, p. 356. 
distribuição de produtos, em aumentar a produtividade do trabalho e socializar a produção na prática. ${ }^{31}$

Uma vez expropriada a burguesia fabril, era preciso também encontrar um meio para incorporar o seu conhecimento. A difusão da ciência e da técnica gerada pelo capitalismo, segundo a perspectiva de Lênin, em As tarefas Imediatas do Governo Soviético, constituía um elemento imprescindível para o estabelecimento de uma base de produção, que pudesse abrir terreno para a transição socialista. Nesse sentido, tendo em vista o nexo intrínseco da técnica com a exploração capitalista, fazia-se necessário adaptar tais formas de produção ao contexto soviético, aproveitando seus aspectos mais progressistas. Os organizadores do processo produtivo, os especialistas no conhecimento, eram de origem burguesa e apenas eles poderiam, no contexto da implementação da NEP, realizar o projeto de reorganização do trabalho. A respeito da necessidade de ampliação da produtividade do trabalho, Lênin considerava que

[...] a última palavra do capitalismo neste terreno - o sistema Taylor -, do mesmo modo que todos os avanços do capitalismo, reúne em si toda a ferocidade refinada da exploração burguesa e uma série das maiores conquistas científicas referentes ao estudo dos movimentos mecânicos durante o trabalho, a supressão dos movimentos supérfluos e, a elaboração de métodos de trabalho mais racionais, a implantação de melhores sistemas de registro e controle. A República Soviética deve adotar, a qualquer custo, as conquistas mais valiosas da ciência e da técnica neste domínio. A possibilidade de se construir o socialismo depende precisamente do êxito que logremos ao combinar o poder soviético e a organização soviética da direção com as últimas conquistas do capitalismo. ${ }^{32}$

\footnotetext{
${ }^{31}$ LENIN, V. I., "The Tasks of the Proletariat in Our Revolution (Draft Platform for the Proletarian Party)" in Lenin Collected Works, Progress Publishers, 1964, Moscow, Volume 24, pp. 55-92.

${ }^{32}$ Idem, Loc. Cit.
} 


\section{V: Rumo à construção do cinema soviético: 1924-1925}

Inserida no contexto da reconstrução econômica do Estado soviético, alavancado pela implementação da NEP, a formação da indústria cinematográfica soviética no início da década de 1920 foi marcada pela luta empreendida pela classe cinematográfica (diretores, críticos, profissionais do ramo, etc.) contra o caos organizacional que reinava nos órgãos governamentais culturais (Narkompros ${ }^{33}$ ) e nas empresas estatais que detinham o monopólio da distribuição (Goskino ${ }^{34} \mathrm{e}$, posteriormente, Sovkino ${ }^{35}$ ). Essa mobilização em prol da construção de um "cinema soviético" (a partir dos escombros do cinema czarista) além de estabelecer uma base material para a reestruturação da atividade cinematográfica nas repúblicas soviéticas, também abriu caminho para a formação de um cinema esteticamente radical. Baseados em diversos experimentos estilísticos com as técnicas de edição e influenciado pelas experiências vanguardistas cubo-futurista e construtivista (no campo das artes plásticas), cineastas como Sergei Eisenstein (1898-1948), Dziga Vertov (1896-1954), Vsevolod Pudovkin (1893-1953) e Esther Shub (1894-1959) ampliaram os horizontes da então jovem cinematografia soviética, nos primeiros anos de estabilidade econômica (a partir de 1923).

\footnotetext{
${ }^{33}$ O Comissariado do Povo para o Esclarecimento (Народный комиссариат просвещения, abreviação: Наркомпрос) foi o órgão ministerial soviético, subordinado do Sovnarkon (Совет Народных Комиссаров - Conselho dos Comissários do Povo), encarregado da administração pública da educação e da cultura entre 1917 e 1946. Sobre este ponto, ver FITZPATRICK, Sheila, The Commissariat of Enlightenment: Soviet Organization of Education and the Arts Under Lunacharsky, Cambridge University Press, 2002.

34 Comitê estatal para cinematografia da URSS (Государственный комитет по кинематографии СССР, abreviação: Госкино). Órgão do governo bolchevique que exerceu o monopólio de distribuição de filmes na URSS durante os primeiros anos da NEP. Também desenvolvia atividades de produção de filmes, tal como um estúdio cinematográfico.

${ }^{35}$ Empresa estatal de capital aberto soviética organizada para atuar no setor de produção e distribuição de filmes em meados de 1924. Foi designada pelo governo bolchevique para substituir a Goskino na questão da distribuição de títulos cinematográficos para a rede de exibição em todas as repúblicas soviéticas durante o restante da década de 1920.
} 
No entanto, a necessidade de somas consideráveis, para construção de uma base material para o desenvolvimento do setor (em outras palavras: reformas em salas de projeção, capital para o aumento da produção de filmes, treinamento de profissionais qualificados, etc.), levou a burocracia cultural bolchevique, paulatinamente, a direcionar sua atenção para trabalhos voltados para "interesses comerciais". Filmes como A Fumante do Mosselproma ${ }^{36}$ e o Caso dos Três Milhões ${ }^{37}$, pautados pela prática cinematográfica do período czarista, eram facilmente compreendidos pelo público, acostumado com dinâmica narrativa de títulos estrangeiros - oriundos do "cinema comercial" hollywoodiano e europeu ocidental -, comédias, adaptações literárias, ficção científica, etc.

Apesar do surpreendente sucesso de As Extraordinárias Aventuras de Mr. West na terra dos Bolcheviques, ${ }^{38}$ comédia de Kuleshov lançada em 1924 - o primeiro filme soviético a adaptar o gênero cômico a uma narrativa "anticapitalista" -, os profissionais do cinema estavam longe de uma postura otimista em relação à cinematografia soviética. Nas cidades, os teatros (as salas de exibição eram, em sua maioria, teatros adaptados com telas de projeção) enfrentavam sérios problemas financeiros, advindos da disparidade entre o poder de compra do proletariado e o preço das entradas (que era regulado pelo Estado), além do baixo número de títulos para exibição. As condições de produção, distribuição e exibição eram precárias. As sessões de exibição geralmente não eram pontuais, e, de acordo com alguns visitantes alemães, mesmo os teatros moscovitas (considerados os melhores) eram de aparência antiquada, sofrendo também da falta de orquestras. Já os teatros provincianos sofriam de um excesso de títulos com temas "pequeno-burgueses", sem contar suas condições estruturais "primitivas" (higiene, estado de conservação dos equipamentos, etc.). Os administradores das salas de exibição eram forçados pela

\footnotetext{
${ }^{36}$ Papirosnitsa ot Mosselproma, URSS, 1924, Dir. luri, Zheliabuzhskii.

37 Protsess o tryokh millionakh, URSS, 1926, Dir. lakov Protazonov.

${ }^{38}$ Neobychainye priklyucheniya mistera Vesta $v$ strane bolshevikov, URSS, 1924.
} 
Goskino a aceitar os filmes disponíveis em seu catálogo (que era escasso, em se tratando em número de títulos, predominantemente películas estrangeiras, com temas "burgueses"), sendo que a maioria dos rolos chegava fora dos prazos, dificultando a divulgação antecipada das sessões.

É importante ressaltar que o decreto de nacionalização do cinema, promulgado por Lênin em 1919, não trouxe mudanças substanciais na forma como os soviéticos já estavam lidando com a prática cinematográfica, nos primeiros anos da revolução. De certa maneira, foi uma medida emergencial de regulação, que visava atribuir autoridade aos órgãos estatais (NARKOMPROS, principalmente) a fim de administrar ativos e materiais cinematográficos durante o período caótico da guerra civil. $\mathrm{O}$ ato de nacionalização não veio acompanhado de um programa de longo prazo de fiscalização das atividades de produção e exibição (que passaram a ser exercidas, em larga escala, pela iniciativa privada, a partir de 1921), e não estipulou estratégias para a construção de um "cinema soviético". Descentralização e iniciativas locais foram fatores chave para o desenvolvimento da prática cinematográfica na URSS ${ }^{39}$. As práticas mercantis vigentes durante o período da NEP (entre os anos de 1921 e 1928) proporcionaram uma autonomia econômica às empresas do ramo, e as primeiras tentativas de centralização por parte do governo, com a criação da Goskino, em 1922, tiveram que se apoiar nos sistemas de produção e distribuição desenvolvidas pelas organizações das diversas províncias.

Contudo, em 1924, o monopólio estatal sobre a importação e distribuição de filmes na URSS já se mostrava falho. Sediada em Moscou, a Goskino tinha como principal objetivo garantir o controle do estado sobre as operações da indústria cinematográfica - importação de película virgem para as empresas de produção, aquisição de títulos estrangeiros para as salas de exibição, etc. - e, ao mesmo tempo,

\footnotetext{
${ }^{39}$ KEPLEY Jr., Vance, "Federal Cinema: The Soviet Film Industry, 1924-32" in Film History, Vol. 8, No. 3, Bloomington, Indiana University Press, 1996, pp. 334-356.
} 
fiscalizar as operações das empresas privadas que atuavam no ramo, segundo as práticas econômicas da NEP. No entanto, os investimentos governamentais para a execução de tais tarefas se mostravam insuficientes, uma vez que a Goskino tivera sérias dificuldades para manter seu programa interno de produção de filmes atividade secundária, que requeria quantias bem menores do que o trabalho de importação e distribuição de filmes. Tal postura por parte do Sovnarkom (o órgão máximo do governo soviético) deixava claro sua política para o cinema: o pequeno repasse de recursos governamentais para o setor era uma motivação para a Goskino procurar alternativas para a obtenção de recursos (não estatais) por meio das negociações com estúdios privados (incluindo os estrangeiros) e salas de exibição (uma vez que era detentora do monopólio da distribuição). Em outras palavras, a indústria cinematográfica soviética deveria obter lucros com a distribuição a fim de reconstruir sua base material de produção de filmes. Contudo, ao longo de seus primeiros anos de existência, a estatal dava repetidas mostras de falhar completamente na execução de tal tarefa.

Na primavera de 1924, a Conferência da União de Todas as Organizações de Cinema foi convocada para analisar problemas de organização da indústria cinematográfica. Embora a conferência tenha focado seu debate principalmente nas falhas da Goskino, ela também tratou de apontar diretivas para ações estratégicas futuras. Ainda que houvesse acordo quanto à manutenção do monopólio do governo soviético sobre a distribuição de títulos (monopólio este, vale lembrar, que não tinha se concretizado) em todas as repúblicas da URSS, certas propostas, como a da unificação das organizações de cinema em uma empresa de capital aberto, permaneciam sob polêmica. A controvérsia dizia respeito à principal questão debatida na conferência: qual modelo de organização da produção e distribuição de filmes que deveria substituir o "monopólio" da Goskino? A constatação de que a companhia não conseguira estabelecer uma rede de associações entre empresas privadas e 
organizações estatais, de modo a criar uma dinâmica produtiva que pudesse fortalecer a atividade cinematográfica, era evidente para os participantes da conferência. De certa maneira, o desastre administrativo da proposta de monopólio estatal nos primeiros anos da NEP ilustrou, para as organizações soviéticas de cinema, os perigos de um controle burocrático geral (glavism), centrado em apenas uma companhia.

A Sovkino - empresa de distribuição estatal fundada por resolução governamental no Trigésimo Congresso do Partido Comunista, em 1924 - foi, em certa medida, a resposta imediata do governo soviético para os problemas financeiros e técnicos que afligiam tanto a produção (ausência de estocagem de películas virgens e atualização do maquinário - câmeras, aparato de iluminação, etc.) quanto a distribuição (falta de projetores, de conforto das salas de exibição e de precisão no cronograma de distribuição de títulos).

Em todo caso, havia um consenso, por parte das administrações dos estúdios de cinema soviéticos privados, de que a formação da Sovkino como empresa estatal de capital aberto, ao invés de um sindicato do setor de produção de filmes (por exemplo), era a solução mais viável (e também inevitável) para a resolução do problema do monopólio de distribuição. A pressão externa dos acionistas particulares obrigaria a estrutura burocrática da recém criada companhia a ser mais diligente com sua dinâmica de trabalho, a fim de evitar entraves que desviassem a empresa de suas metas de lucro. Além disso, tal estrutura de gestão visava também atender às demandas da comunidade dos trabalhadores do cinema (profissionais assalariados do ramo: diretores, atores, roteiristas, câmeras, etc.), uma vez que o modelo "cem por cento estatal" da Goskino não fora capaz de proporcionar melhorias nas condições de trabalho nos estúdios e formação/capacitação de novos profissionais para o ramo.

É importante notar que a crise do cinema soviético nos primeiros anos da NEP não foi resultado apenas de falhas gerenciamento, mas também da escassez de 
recursos humanos qualificados para a tarefa de construir uma base de produção cinematográfica que pudesse superar a dependência da importação de filmes estrangeiros. O problema da falta de trabalhadores qualificados era proveniente da carência de oportunidades de treinamento. Escolas técnicas de cinema havia, mas não numa escala que pudesse - naquele momento - dar conta da expectativa de crescimento. Diretores como Kuleshov e Vertov davam especial atenção a esse problema. Ambos desenvolveram trabalhos educacionais em seus coletivos e no Instituto Estatal para a Técnica Cinematográfica. ${ }^{40}$ Todavia, tinha-se a concepção de que o treinamento no campo do cinema deveria dar ênfase primeiramente ao aspecto político dos filmes que seriam produzidos pelos futuros profissionais. Tanto Vertov quanto Kuleshov consideravam que a revolução no cinema soviético não se realizaria, caso não se prestasse atenção ao domínio técnico dos materiais. Mas, no final das contas, ficava a questão: primeiramente educar politicamente os jovens profissionais, sob o risco de se tornarem tecnicamente incompetentes, ou deixá-los aprender com os técnicos do período pré-revolucionário, com o perigo de suas convicções estéticas se aproximarem da ideologia burguesa do passado?

Nós não sabemos como lidar com o material de nosso ofício; nós não sabemos como, porque nós não queremos estudar; nós não sabemos como, e conseqüentemente, nós não nos familiarizamos com o lado formal de nossa cinematografia.

A fim de saber como mostrar pessoas realmente interessantes e expressivas, os movimentos organizados das massas [...], e, finalmente, obter o correto desenvolvimento da trama, é essencial saber e saber como. Saber todas as características e peculiaridades da cinematografia, saber como administrar e saber como obedecer. ${ }^{41}$

\footnotetext{
40 A Gosudarstvennyi tekhnikum kinoiskusstva, fundada em 1919 e regulada pelo NARKOMPROS, tratava-se de uma escola de cinema que tinha como objetivo a formação de profissionais (diretores, roteiristas, cameramans, etc.) para o setor.

${ }_{41}$ KULESHOV, Lev, "Priamoi put" Kino-Gazeta, n. 48, 1924, p.2. Apud. YOUNGBLOOD, Denise, Op. Cit., p. 26. Ver também KULESHOV, Lev, "Art' Cinema", in TAYLOR, Richard (Edited and Translated by), The Film Factory: Russian Soviet Cinema in Documents, Cambridge, Massachusetts, Harvard University Press, 1988, pp. 68.
} 
Todavia, tal problema não consistia apenas na questão dos conteúdos dos filmes - o tratamento dos elementos históricos e políticos da trama e as estratégias de construção fílmica mais apropriadas para a sua apresentação -, mas também compreendia outro aspecto (de caráter material) que, de certa forma, era preponderante: a escassa disponibilidade de aparelhagem e materiais para a filmagem (câmeras, iluminação, etc.), revelação (estúdios e agentes químicos para o tratamento dos filmes) e montagem (moviolas). Os poucos equipamentos disponíveis forçavam os técnicos a recorrer ao improviso. Um dos cinegrafistas (ou cameraman) mais experientes e conhecidos da época, Alexandr Levitskii, considerava que o aparato técnico dos estúdios soviéticos estava em um nível "abaixo de qualquer crítica". ${ }^{42}$ Tendo em vista o fato de que, no cinema do período, os operadores de câmera eram praticamente os diretores técnicos do filme (diziam aos diretores o que era possível e o que não era possível de ser feito, considerando os limites do aparato técnico disponível), sua opinião tinha um peso considerável. Levitskii também considerava que o fato dos cameramans soviéticos serem forçados a trabalhar principalmente com a luz natural, tendo em vista uma total falta de equipamentos adequados para o trabalho em sets fechados, constituía um fator negativo para o desenvolvimento de uma cinematografia de qualidade. A parafernália de iluminação disponível era, de longe, ultrapassada, desperdiçava uma quantidade enorme de eletricidade, e, acima de tudo, era perigosa (risco de explosões e incêndio, caso permanecesse ligada por um período longo). Além disso, a amperagem média disponível em Moscou era de aproximadamente 2000 amperes, bem abaixo da média dos estúdios americanos, que girava em torno dos 40 a 50.000 amperes.

Em A Greve (Stachka, URSS, 1925), Eisenstein, auxiliado pela técnica fotográfica de Eduard Tissé (1897-1961), “aproveita” a limitação dos aparatos de

\footnotetext{
${ }^{42}$ A. Levitskii, Rasskazy o kinematografe, Moscow, 1964, apud CAVENDISH, Philip, The Hand that Turns the Handle: Camera Operators and the Poetics of the Camera in Pre-Revolutionary Russian Film, in THE SLAVONIC AND EAST EUROPEAN REVIEW, Volume 82, Number 2, April 2004, p. 203.
} 
iluminação disponíveis, criando um contraste claro/escuro, que reforça os diversos "tipos" que aparecem durante o decorrer da narrativa, assim como as ações revolucionárias dos operários (ambientes claros, a luz do dia) e as "maquinações" contra-revolucionárias das personagens burguesas (espaços permeados de sombras). Os rostos dos inimigos do proletariado aparecem geralmente emoldurados por fundos pretos e são iluminados por uma única fonte de luz, permitindo que espectador diferencie com facilidade os traços fisionômicos das personagens. Alguns desses tipos são seguidos por letreiros curtos que reforçam sua caracterização. Como exemplo, podemos citar o supervisor dos operários (figura 1) - de aspecto franzino (em contraposição ao vigor físico dos trabalhadores grevistas) e marcado por legenda que aponta seu status na fábrica (figura 2), e o carvoeiro (figura 3), funcionário encarregado de tocar o sinal que regula os turnos. Sua truculência é assinalada por letreiro provocativo (figura 4), que prenuncia um combate cômico entre dois operários grevistas que almejam tocar o sinal fora do horário. O diretor utiliza também a iluminação para criar espaços recortados de seus ambientes habituais. A mesa do chefe de polícia (figura 5) é mostrada envolta por uma penumbra que recobre todo seu ambiente de trabalho (normalmente, um oficial de alto cargo teria recursos de sobra para manter uma iluminação adequada em seu escritório). Eisenstein não está interessado, nesse momento, em caracterizar a personagem, mas em criar um cenário estilizado, para a aparição da araponga "Raposa" (figura 6), e enfatizar sua ação na cena: ato da entrega de arquivos secretos sobre os grevistas a um alto oficial da polícia. Deste modo, o diretor visa destacar a ação "contra-revolucionária" (neste caso, o trabalho de espionagem). Em outro momento do filme, quando o mesmo oficial requisita documentos sobre o distrito industrial a um subordinado (uma ação aparentemente rotineira), seu escritório, ao contrário da seqüência acima mencionada, é filmado com um ângulo de câmera que mostra toda a extensão do escritório do oficial (mais fortemente iluminado). 


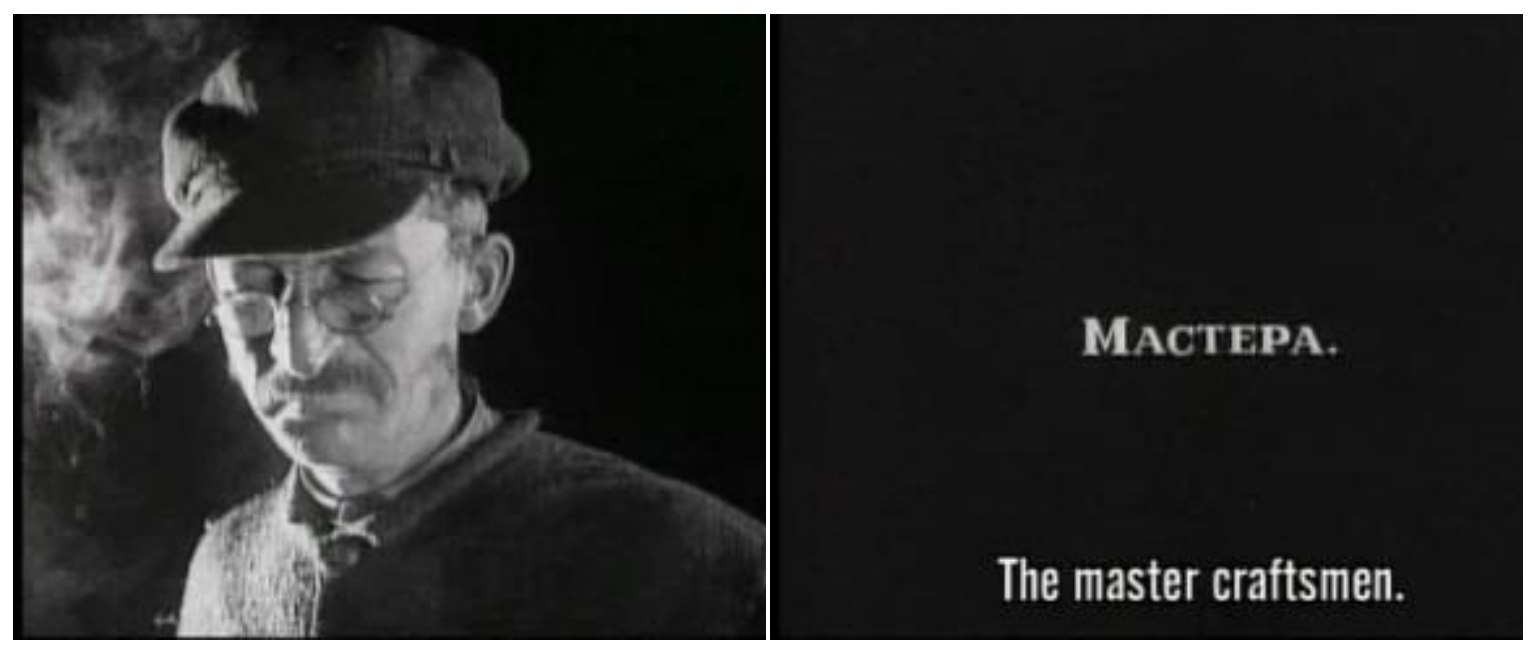

Figura 1

Figura 2

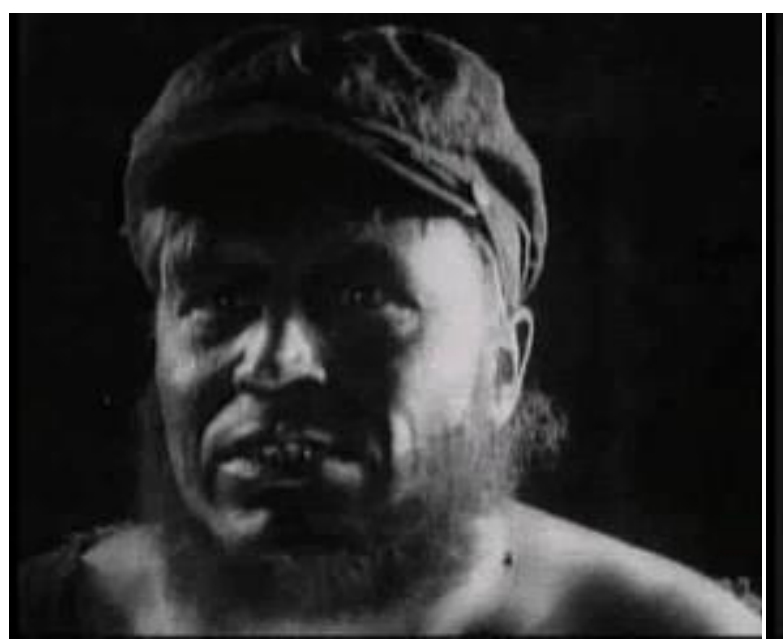

Figura 3

- IIIIE $\mathbf{K}$...

"Go to hell!"

Figura 4

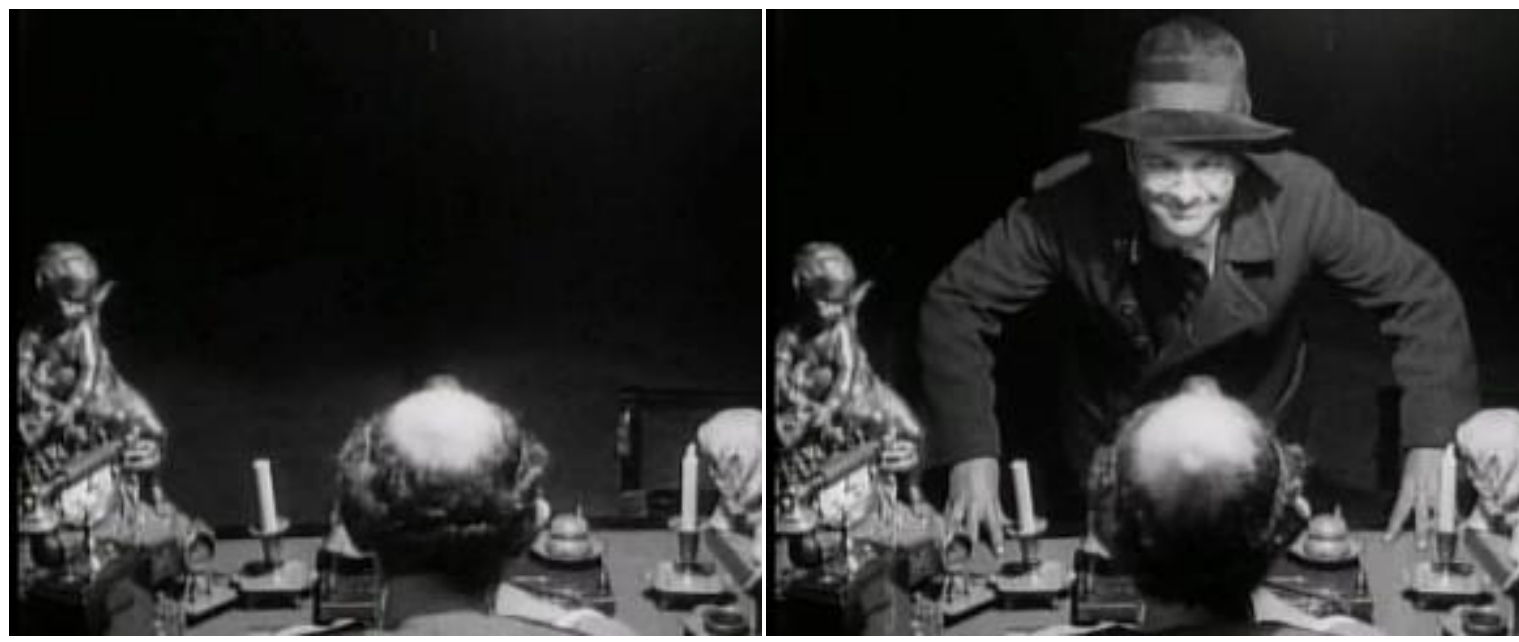

Figura 5

Figura 6 
Além da questão da iluminação, a prática da "reedição" (перемонтаж peremontahz) consistiu também em outra forma de "improviso", que os profissionais do cinema soviético desenvolveram para superar as dificuldades relativas à questão da distribuição. Embora aproximadamente noventa e cinco por cento do mercado de distribuição soviético entre os anos 1923 e 1925 consistisse na comercialização de filmes estrangeiros, o número de títulos importados geralmente não dava conta de suprir a demanda das salas de projeção. A solução encontrada pelas empresas cinematográficas soviéticas foi engenhosa: "remontar" os filmes. Tal prática consistia na re-elaboração de seqüências inteiras por meio da montagem, supressão de cenas nas quais os conteúdos fossem considerados impróprios (apologia a temas relativos ao capitalismo, principalmente) e inserção de letreiros de modo a alterar a estrutura narrativa.

Contudo, segundo o historiador Yuri Tvisian, tal prática da cultura cinematográfica soviética na década de 1920, não se limitava apenas à supressão de cenas e alteração e letreiros. Também abrangia a alteração do título principal, mudança do nome de personagens e a adição de cenas já existentes na metragem. Grosso modo, a peremontahz consistia na completa adaptação do filme para o público de um país estrangeiro. Nesse sentido, a reedição não era apenas praticada em filmes estrangeiros importados para o mercado russo: se um filme soviético fosse exportado para um determinado país, ele também sofreria alterações, a fim de se adaptar ao mercado do país importador (vale lembrar que estamos falando de uma época de sérias dificuldades financeiras para o cinema soviético). Portanto, a prática russa da reedição de filmes consistia em "repensar o filme", de acordo com as especificidades do público ao qual se dirigiria. ${ }^{43}$

\footnotetext{
${ }^{43}$ TVISIAN, Yuri, "The Wise and Wicked Game: Re-editing and Soviet Film Culture of the 1920s", in Film History, Vol. 8, №. 3, Bloomington, Indiana University Press, 1996, p. 336.
} 
Em fevereiro de 1924, Eisenstein e Shub foram encarregados de trabalhar numa remontagem que condensaria os dois episódios de Doctor Mabuse, Der Spieler, de Fritz Lang (que já tinham sido lançados em 1922) em apenas um longa metragem. Para Eisenstein o elemento chave de tal procedimento era o raciocínio do montador. Raciocínio este que poderia desconstruir um filme pouco atrativo - uma narração linear e monótona -, mudando as identidades das personagens, jogando fora uma trama coerente, reorganizando-a de maneira excêntrica, mediante adição de letreiros inusitados. Até aquele momento, exceto pelas filmagens de O Diário de Glumov curta-metragem produzido para a peça O Sábio, de 1923 - o diretor não tivera contato com a prática da edição. Considerando que a reedição consistia na reconstrução da estrutura fílmica, é possível supor que, às vésperas das filmagens de $A$ Greve, Eisenstein se interessasse por compreender como a montagem influía na recepção do espectador (ocorre que, os filmes "remontados" eram, em sua maioria, títulos estrangeiros de sucesso) e conhecer as estratégias utilizadas pelos montadores russos para manipular o sentido das narrativas, mediante o uso de letreiros e reformulação das seqüências fílmicas. Nesse sentido, é possível deduzir que a incorporação do elemento visual gráfico (a manipulação da palavra nos letreiros, as variações de tamanho, tipos, etc.), em Eisenstein, possa ter derivado da experiência dos montadores treinados nesse trabalho específico de edição. 


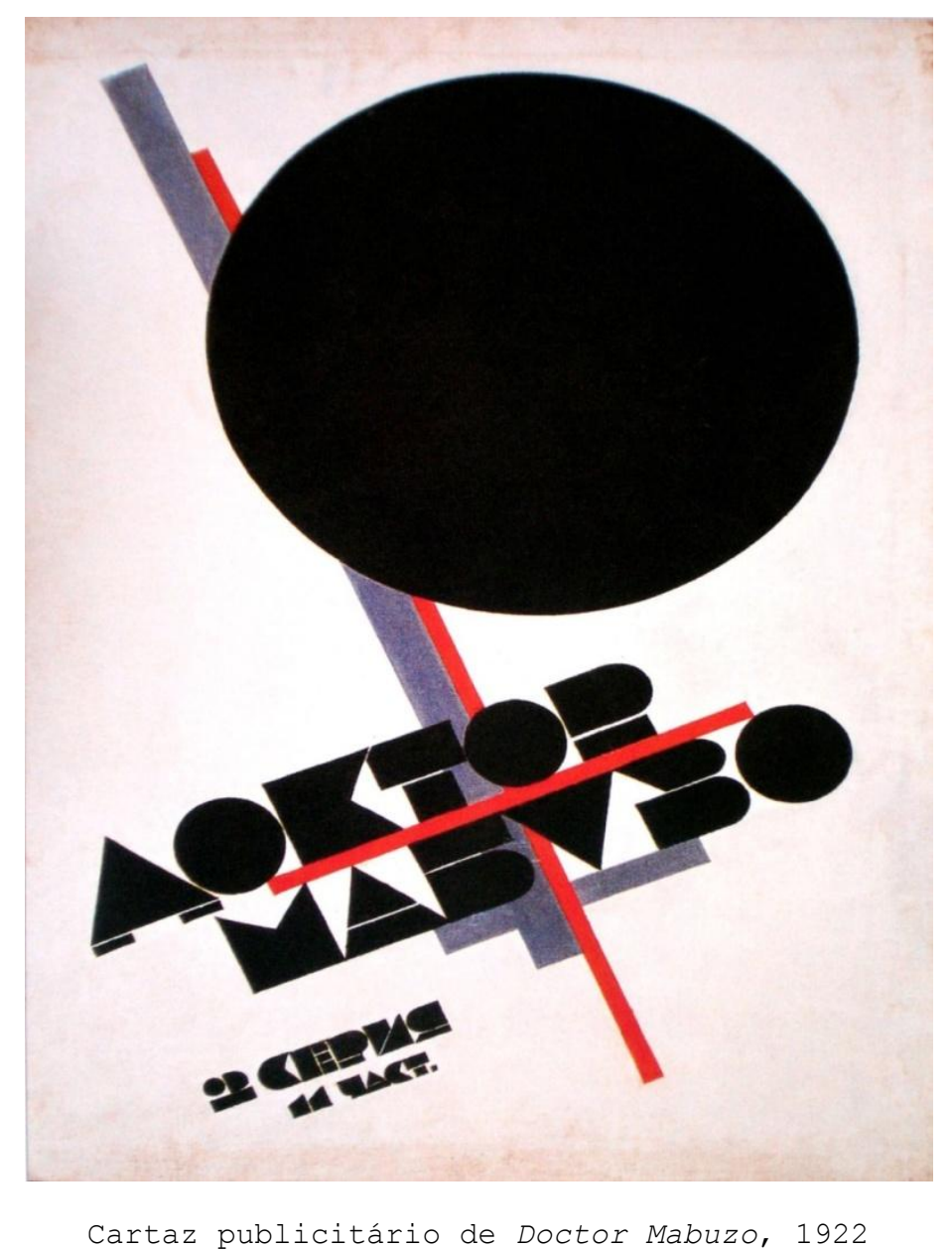

A utilização dos letreiros como elemento encadeador de fragmentos fílmicos se constitui numa característica marcante do trabalho do cineasta. Exemplo digno de nota é o prólogo de $A$ Greve. Eisenstein utiliza a frase "Na fábrica está tudo calmo, mas os operários estão descontentes" para ordenar uma série de planos distintos, cronologicamente não determinados, mas que, de certa maneira descrevem o espaço onde se desenrola a narrativa. O letreiro "Na fábrica tudo está calmo..." aparece primeiro como título da primeira parte do filme (figura 7), seguido de quadros rápidos que descrevem o ambiente de normalidade da fábrica: chaminés a todo vapor (figura 8), um diretor da fábrica (mostrado em close-up frontal), aparentemente contente com a produção (figura 9) e o ambiente da linha de montagem (apresentado via travelling), em pleno funcionamento (figura 10). Após os curtos planos descritivos, o letreiro aparece novamente, porém com uma fonte diferente (em negrito) acompanhado da 
palavra "mas" - HO - em destaque, impresso em uma terceira fonte (figura 11). O "HO" é novamente destacado, tomando conta de todo a extensão do fotograma. Em seguida o "H" começa a se mover, desloca-se para trás do "O", desaparece enquanto o "O" gira e, por fim, transforma-se em uma roda de ventilação em movimento (figuras 12, 13 e 14). Após esse fragmento, que remete a técnicas de cinema de animação de acordo com Albera, "se observarmos com atenção uma cópia de boa qualidade, pode-se ver que as letras escritas são substituídas por letras cortadas, presas por mãos com luvas pretas que passam pela abertura de uma cortina escura - a seqüência continua com sombras de operários confabulando, em menção clara à clandestinidade da atividade revolucionária (figura 15). Finalmente nos é mostrado o desfecho da frase "mas os operários estão descontentes" (figura 16) e, em seguida, o cineasta utiliza planos abertos onde mostra o mesmo ambiente fabril, outrora apresentado em sua normalidade, e agora repleto de operários organizando o movimento grevista (figuras 17 e 18).

Deste modo, Eisenstein, já em seu primeiro filme, trabalhava para reconstruir o modo de utilização da palavra escrita no cinema, reagindo assim à ineficácia dos letreiros dos filmes estrangeiros reeditados - que, na sua maioria, não conseguiam passar a mensagem revolucionária ${ }^{44}$ - bem como dos filmes soviéticos realistas, que em certa medida - atrapalhavam a continuidade das cenas e o aspecto plástico das seqüências.

\footnotetext{
${ }^{44}$ Segundo Tvisian, a tradução e reformulação dos letreiros dos filmes estrangeiros remontados visavam à supressão ou reformulação de conteúdos impróprios para o público soviético (por exemplo, filmes que faziam apologia ao capitalismo), assim como à inserção da perspectiva do socialismo nas narrativas. Embora tal prática fosse corrente na URSS durante a década de 1920, Tvisian ressalta que, até 1924, não existiam padrões de qualidade específicos para o trabalho de re-montagem. Ocorre que tal falta de padronização da atividade culminava no lançamento de filmes com letreiros excessivamente longos (e difíceis de serem lidos) que inseriam atabalhoadamente discursos sobre "valores" revolucionários, e também com seqüencias "mutiladas" (sem um nexo bem elaborado). Ver TVISIAN, Yuri, Op. Cit., pp. 330334.
} 


\section{1}

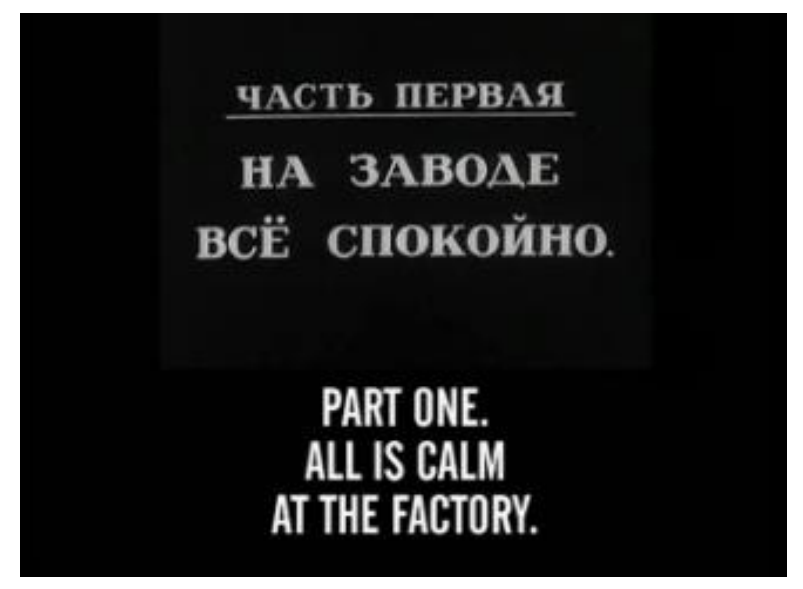

Figura 7

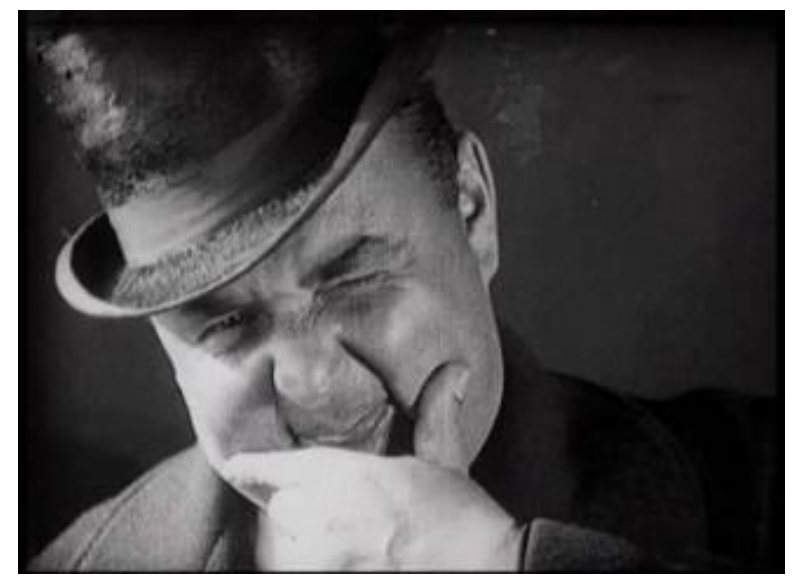

Figura 9

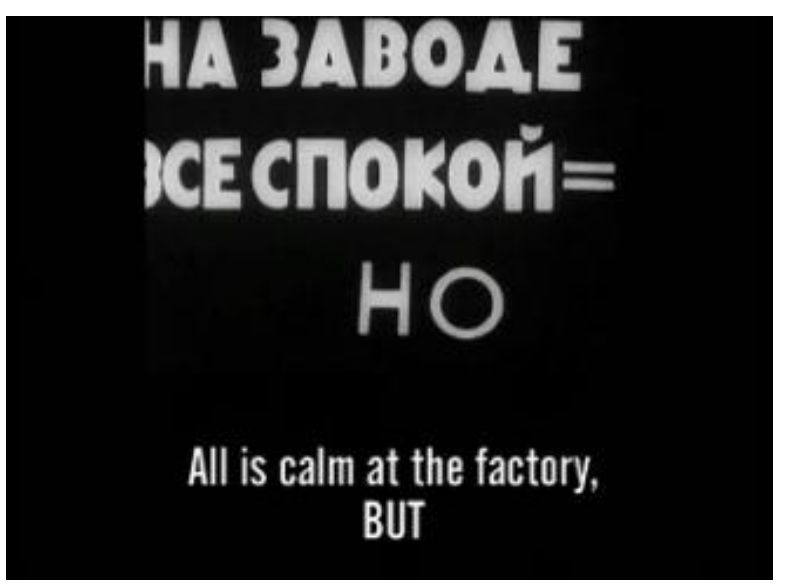

Figura 11

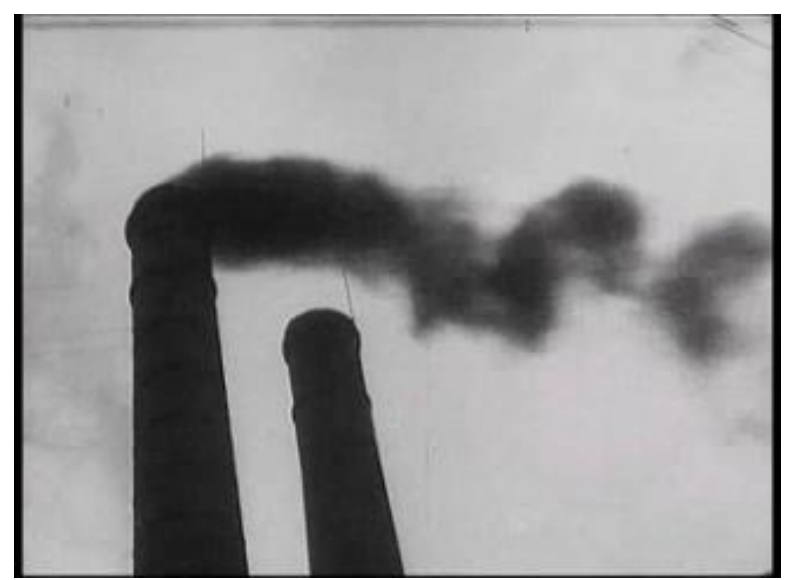

Figura 8

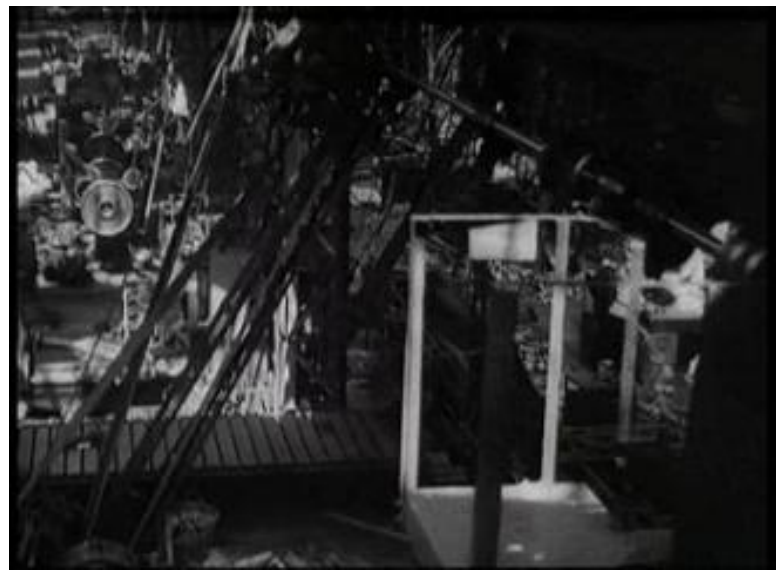

Figura 10

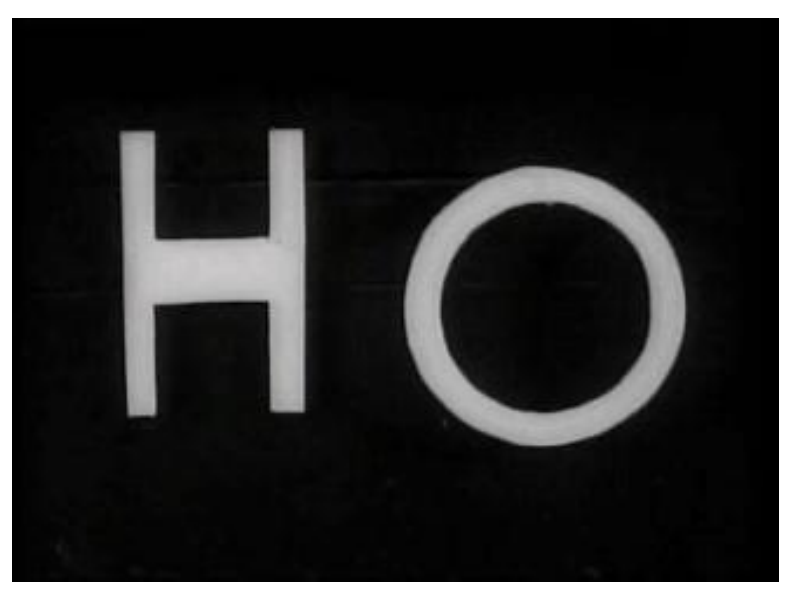

Figura 12 


\section{Continuar a Revolução...}

Produzido em 1924, em colaboração com o primeiro teatro operário da Proletkult, A Greve contou com atores de origem operária e consistiu fundamentalmente numa obra de agitação política, sem precedentes no cinema. Diante das novas condições sociais impostas pela dinâmica de mercado da NEP (o reaparecimento da burguesia e a reestruturação do capitalismo de estado), A Greve - o filme feito por trabalhadores e para os trabalhadores - tencionava intervir diretamente no novo contexto da luta de classes que se configurava na URSS (os operários versus a burguesia urbana - os chamados NEPmen - e os camponeses dos kolkhoze versus os Kulaks latifundiários)

O filme foi fruto de um projeto cinematográfico ousado, elaborado por um grupo de escritores e atores do Teatro Central da Proletkult de Moscou, mas que não se completou integralmente. Supervisionado por Eisenstein e Valerian Pletnev (1886 - 1942), este grupo trabalhou num conjunto de roteiros, compreendendo uma série de sete filmes, que se constituiriam numa síntese de "todas as lições apreendidas pelos trabalhadores russos em suas lutas anteriores à Revolução [de 1917] (em greves, atividades clandestinas, publicações ilegais, organização política, etc.)", a saber: 1) Genebra-Rússia, 2) Subterrâneo, 3) Primeiro de maio, 4) 1905 , 5) A Greve, 6) As rebeliões nas 
prisões e fugas e 7) Outubro. ${ }^{45}$ De tal série, Stachka ( $A$ Greve) foi o único filme produzido, em 1924.

Segundo Eisenstein, o coletivo envolvido na elaboração do argumento do filme procurou "deixar de lado a concepção individualista do herói burguês", a fim de "retratar o conceito de 'coletividade"'. ${ }^{46}$ Para o diretor, a reflexão sobre a noção de coletividade visava a uma necessidade urgente para a cinematografia soviética, uma vez que "nenhum filme havia apresentado até então uma imagem de ação coletiva". ${ }^{47}$ A noção de coletividade, o Klassovost (palavra em russo que pode ser traduzida tanto como "personagem de classe" quanto "consciência de classe"), elaborada por Eisenstein em conjunto com o grupo de artistas da Proletkult que participou da produção de $A$ Greve, se traduziu num elemento de construção cinematográfica inovador: a classe operária como personagem protagonista da trama. ${ }^{48}$

A Greve se inicia com um letreiro no qual há uma citação extraída do texto A Disciplina do Partido e A Luta Contra os Social-democratas pró Kadets ${ }^{49}$, escrito por Lênin em 1905: "A força da classe proletária está em sua

\footnotetext{
${ }^{45}$ LEYDA, Jay, KINO: Historia del cine ruso y soviético, Buenos Aires, Editorial Universitaria de Buenos Aires, 1965, p. 218.

${ }^{46}$ EISENSTEIN, Sergei, "Do Teatro ao Cinema”, apud. LEYDA, Jay, Op.Cit., Loc. Cit.

${ }^{47}$ Idem, p. 218-219.

${ }^{48}$ É importante ressaltar que Pletnev - um dos líderes mais importante da direção nacional da Proletkult, escritor de peças de teatro e bolchevique desde a Revolução de 1905 - participou da elaboração da série de roteiros dos quais A Greve fazia parte. Segundo a historiadora Lynn Mally, Pletnev era conhecido por escrever peças com temas relativos à questão do movimento operário e da Revolução. Dentre seus trabalhos mais conhecidos, pode-se citar $O$ Vingador (Msititel'), um conto heróico sobre o auto-sacrifício de revolucionários durante a Comuna de Paris, Greves (Stachki), adaptação de um conto de Leksei Gastev (1882-1939) sobre um grupo de jovens que se engajam em um protesto trabalhista na Rússia pré-revolucionária, Improvável, mas possível (Neveroiatno, no vozmozhno), uma farsa sobre o Governo Provisório, dentre outros. Ver MALLY, Lynn, Culture of the Future: The Proletkult Movement in Revolutionary Russia, Berkeley, University of California Press, 1990, pp. 142-143.

${ }^{49}$ LENIN, V. I., "Party Discipline and the Fight Against the Pro-Cadet Social-Democrats", in Lenin Collected Works, Progress Publishers, 1965, Moscow, Volume 11, pages 320-323. O termo Kadet era uma referência genérica um membro do Partido Democrata Constitucional (conhecido na época pela sigla KD).
} 
organização [...] Organização quer dizer unidade de ação, unidade de atuação prática" ${ }^{50}$ A sentença de Lênin, elaborada diante dos revezes da Revolução de 1905 (o texto fora publicado no oitavo número do jornal Proletary, em novembro de 1906, momento no qual as greves gerais de 1905, chamadas pelos Soviets de Moscou e São Pertersburgo, já haviam sido derrotadas), referia-se à necessidade urgente de organização do operariado russo, e apontava para a importância do papel do Partido Bolchevique em oposição às posições reacionárias dos Mencheviques, aliados aos deputados do Partido Democrata Constitucional, eleitos para Duma Constitucional (dissolvida meses depois pelo czar).

Embora o enredo de $A$ Greve não se detenha especificamente sobre tais fatos, eles estão implicados como pano de fundo, pondo o contexto para a reflexão histórica do espectador. A narrativa do filme apresenta as diferentes etapas do processo de mobilização e organização de uma greve: as condições de trabalho que levam os operários a se revoltar, os conflitos com a gerência da fábrica, a negociação com os acionistas, a repressão policial, etc. O tema é apresentado, de modo sintético, no primeiro letreiro após os créditos (a citação de Lênin), e as partes que compõem a narrativa de $A$ Greve não evocam fatos históricos concretos, mas uma interpretação do processo histórico, do ponto de vista das classes (os operários e os capitalistas) que travaram embate. Nesse sentido, é possível afirmar que a citação Lênin, já na primeira seqüência do filme, constitui o nexo que amarra os elementos da narrativa e apresenta 0 mote do filme: a organização independente como um elemento crucial para o

\footnotetext{
${ }^{50}$ Idem, p. 320.
} 
sucesso da luta do operariado. Sobre tal questão, Lênin também afirmara, em

1917, que

[...] os operários e camponeses uniformizados foram a alma das insurreições. [...] O movimento abarcou a maioria dos explorados. Porém o que faltou a este movimento foi, por um lado, firmeza e resolução das massas [...] e, por outro lado, faltou a organização dos operários revolucionários social-democratas que estavam recrutados: não souberam tomar a direção nas mãos, colocar-se à frente do exército revolucionário e lançar uma ofensiva contra o poder governamental. ${ }^{51}$

Nesse sentido, $A$ Greve consistia num filme que propunha a rememoração da questão da organização política do proletariado, no âmbito histórico da Revolução de 1905. Todavia, é curioso perceber que tal reflexão foi proposta pelo filme precisamente no momento político no qual o operariado russo era estimulado por Lênin (em 1918) a "aumentar a produtividade do trabalho e socializar a produção na prática". ${ }^{52}$ Tratava-se agora de uma proposta de organização da produção, formulada pelo Lênin "administrador" (no contexto da NEP), diferente daquela forma de organização política levantada pelo Lênin "agitador". Para o "administrador", a construção do socialismo dependia da combinação "do poder soviético e da organização soviética da direção com as últimas conquistas do capitalismo". ${ }^{53}$ Já para os realizadores do filme, Eisenstein e a Proletkult, a perspectiva era possivelmente outra, senão oposta. ${ }^{54}$ Confrontar à administração leninista, a doutrina leninista

\footnotetext{
${ }^{51}$ LENIN, V. I., "Lecture on the 1905 Revolution", in Lenin Collected Works, Progress Publishers, 1964, Moscow, Volume 23, pages 236-253.

52 LENIN, V. I., "The Tasks of the Proletariat in Our Revolution (Draft Platform for the Proletarian Party)" in Lenin Collected Works, Progress Publishers, 1964, Moscow, Volume 24, pp. 55-92. ${ }^{53}$ Idem, Loc. Cit.

${ }^{54}$ É sabido que Pletnev - um dos colaboradores do roteiro de A Greve - posicionava-se radicalmente contra a instauração da NEP. Em Sobre o Front Ideológico, artigo publicado em setembro de 1922, o escritor argumentava que "embora a cultura proletária [Proletkult] tivesse que, necessariamente, incorporar elementos de todas as esferas culturais das diferentes classes sociais, a cultura proletária deveria se engajar na luta contra o individualismo burguês". Segundo Mally, embora este texto de Pletnev não fizesse menção direta à NEP, a ênfase na
} 
da organização independente do operariado terá sido, talvez, a resposta cinematográfica a uma certa "encomenda social": continuar a Revolução, sem recuo, a partir, não da administração, mas das lutas operárias.

questão da organização operária independente (em detrimento aos "avanços da organização da produção capitalista") lançou uma polêmica que incitou Lênin a escrever uma resposta especialmente para este texto. Ver V. F. Pletnev, "Na ideologicheskom fronte," Pravda, September 22, 1922, reprinted with Lenin's criticisms in Lenin o literature, pp. 304-311, apud, MALLY, Lynn, Op. Cit., p. 222. 


\title{
SEGUNDO CAPÍ'IULO:
}

\author{
Construtivismo e Cinema
}

\section{I: Construtivismo: a organização e o uso utilitário dos materiais}

\begin{abstract}
O movimento em favor da arte industrial foi o resultado de três processos revolucionários, cada um ligado historicamente ao outro. Em primeiro lugar, foi a revolução técnica, que transformou, as formas de vida material e criou as premissas para um novo estilo orgânico. Em segundo lugar, foi a revolução interna da arte, quando os artistas passam da imagem às construções e se convertem em organizadores de estilo. Em terceiro lugar, foi a revolução social, que colocou para a sociedade a necessidade de unir todas as atividades entre si, inscritas numa uma coletividade laboral, a da indústria. Essas três revoluções coincidiram aproximadamente no tempo e no espaço e determinaram a formação, na União Soviética, de um grupo de teóricos e de artistas, [...] que introduziu as bases científicas e práticas da arte industrial. ${ }^{55}$
\end{abstract}

O fragmento acima destacado, escrito em 1926 pelo sociólogo e crítico de arte Boris Arvatov (1896-1940), sintetiza a maneira como artistas e teóricos do campo das artes passaram a encarar a prática artística a partir de 1921, quando se ligaram ao construtivismo e, posteriormente, à Frente Esquerda das Artes (entre os anos de 1923-1928). Segundo a perspectiva dos construtivistas, a práxis artística deveria estabelecer uma nova relação entre o campo artístico, a experiência do dia a dia do trabalhador e as relações sócio-políticas que permeavam tal cotidianidade. Inserido no contexto da revolução social e política, levada a cabo pelos bolcheviques, o construtivismo russo foi formulado em grande parte por artistas ligados originalmente a diversas manifestações

\footnotetext{
${ }^{55}$ ARVATOV, Boris, Arte e Producción: El Programa Del Productivismo, José Sanchez (trad.), Madrid, Alberto Corazón Editor, 1973, p. 86.
} 
vanguardistas (suprematismo, cubo-futurismo, etc.) desenvolvidas na Rússia czarista durante a década de $1910 .^{56}$

Durante o período caótico da Guerra Civil (1919-1921), muitos dos artistas que participaram da elaboração do construtivismo contribuíram na execução de tarefas encomendadas pelo governo bolchevique e pelo Exército Vermelho. Certos historiadores encararam tais fatos como indícios que ligavam os ideais construtivistas diretamente aos objetivos políticos do Partido Comunista. Porém, é possível também notar que as concepções utilitárias desenvolvidas pelos construtivistas foram o produto de uma forma de pensar a relação entre a práxis artística e a dinâmica sócio-política (no contexto da Revolução de 1917), a partir de uma perspectiva crítica, que não estava ligada diretamente aos objetivos do partido bolchevique, no campo das artes e da educação.

Estudar o construtivismo soviético da década de 1920, a partir de um ponto de vista histórico, não constitui uma tarefa fácil. Para começar, de acordo com a hipótese do historiador François Albera, exposta em sua tese Eisenstein et Le Constructivisme Russe (1989),

"[...] certa confusão reina na definição do "construtivismo", tendo em vista a extensão que críticos e historiadores da arte - e às vezes artistas - deram a esse termo. As violentas controvérsias que dividiram os vários movimentos que reivindicaram essa tendência na própria URSS; sua adoção mais ou menos legítima, no Ocidente desde 1922 (quando ocorreu a primeira exposição de arte russa em Berlin; $e$ as dificuldades de acesso aos textos, manifestos e

56 Como exemplo pode-se citar Vladmir Maiakovski (1896-1930), Alexandr Rodchenko (18911956), Lyubov Povova (1889-1924) e os irmãos Georg e Vladmir Stenberg (1900-1933, 18991982, respectivamente), dentre outros. 
testemunhos de época proíbem, nesse momento, qualquer pretensão de dizer a "verdade" sobre 0 assunto... ${ }^{57}$

Todavia, a partir da segunda metade da década de 1990, na esteira de estudos mais recentes sobre a vanguarda, houve uma mudança na abordagem destas questões. Pode-se afirmar que o construtivismo passou a ser caracterizado, com mais propriedade, pelo conjunto de práticas, teoricamente elaboradas, no decurso das atividades de pesquisa e debate empreendidas pelo INKHOUK (Instituto de Cultura Artística, 1921-1924), durante o primeiro semestre de 1921. O grupo recém constituído declarou que os seus conhecimentos e experiências, recolhidos a partir de práticas anteriores com a arte de vanguarda, seriam direcionados para a produção de objetos socialmente úteis, ligados organicamente à experiência social que constituiu, no plano político, a Revolução de Outubro. Entretanto, é necessário ressaltar que os participantes eram provenientes das mais diversas vertentes da arte não figurativa ${ }^{58}$ Por essa razão é razoável afirmar que o construtivismo foi um

\footnotetext{
${ }^{57}$ ALBERA, François, Eisenstein e o Construtivismo Russo, São Paulo, Cosac \& Naify, 2002, p. 165. (itálicos meus).

${ }^{58}$ Segundo a perspectiva do historiador John Bowlt, o Instituto de Cultura Artística (INKHUK) foi a principal força que impulsionou o desenvolvimento do construtivismo na arte russa após 1917. Organizado em Moscou, em maio de 1920, e liderado por Vassili Kandinskii (1866-1944), Nikolai Punin (1888-1953) e Vladmir Tatlin (1885-1953), o Instituto tinha como função principal pesquisar elementos artísticos pertinentes aos principais movimentos artísticos russos - tais como o Suprematismo (Malevich), Colorismo (Kandinskii, Matiúchin, Shevchenko), além da "cultura das matérias" (Tatlin), a fim de tentar sintetizá-los em um programa artístico de base científica. As diversas experiências formuladas por Kandinskii no seio do instituto (por exemplo, investigações psicológicas sobre a sinestesia, pesquisa das propriedades físicas dos materiais constituintes da escultura - metal, madeira, cor -, etc.) despertaram o interesse dos círculos artísticos de esquerda. Todavia, as pesquisas elencadas pela direção do INKHUK, ao longo de 1920, não foram assimiladas no programa de trabalho final, tendo em vista o atrito intelectual gerado pelas diversas posições dos membros (artistas, críticos, pesquisadores) que foram se filiando ao instituto. A "arte de laboratório" (alusão à metodologia experimental de trabalho artístico defendida por Kandinski e Malevich) fora veementemente contestada pelo Obshchaya rabochaya gruppa ob’ektivnogo analiza (Grupo Geral de Análise Objetiva em Ação), grupo formado dentro do INKHUK em outubro de 1920. Para Bowlt, o Grupo Geral de Análise Objetiva em Ação fora a mais dinâmica e criativa das facções que se constituíram dentro do INKHUK, suas contribuições foram fundamentais para o surgimento do construtivismo, no outono de 1921. Ver BOWLT, John, "Russian art in the nineteen twenties", in Soviet Studies, Vol. 22, No. 4, London, Taylor \& Francis Ltd., 1971, pp. 575-594.
} 
movimento plural e pautado pelo debate entre diferentes perspectivas sobre forma artística, baseadas na noção de construção (oposta, segundo a perspectiva dos construtivistas, à noção tradicional de composição). ${ }^{59}$

Ocorre que tal pluralidade se constituiu num fator que, de uma perspectiva historiográfica, exige ser analisado com cautela, tendo em vista que a noção de "construção" foi amplamente empregada por diversos artistas do período. Segundo Albera, "o termo fora utilizado por pelos arquitetos ligados ao INKhOUK, e também pelo "manifesto realista" de Naum Gabo" ${ }^{60}$ Nesse sentido, continua o historiador, "para alguns autores, construtivismo tomou o lugar da "arte não objetiva" e, para os outros, o termo substituiu o "objetivismo" (vechtchismo) oriundo da cultura dos materiais de Tatlin.

\footnotetext{
${ }^{59}$ Pode-se dizer que até a Revolução de 1917, não há registros que atestem que os artistas russos, que participaram do movimento construtivista, tenham chamado seus trabalhos de construções. Os dados historiográficos coletados pela historiadora Christina Lodder presentes em Russian Constructivism (1983) - demonstram que o termo "construção", um dos elementos chave para a compreensão da práxis artística do movimento, foi cunhado pelo Primeiro Grupo de Trabalho dos Construtivistas em Ação - conhecido também como Grupo de Trabalho dos Construtivistas -, estabelecido no Instituto de Cultura Artística de Moscou, em março de 1921. O grupo foi composto por Alexei Gan (1889-1942), Alexandr Rodtchenko (1891-1956), Varvara Stepanova (1894-1958), Konstantin Medunetsky (1899-1935), Karl loganson (1890-1929), e os irmãos Georg e Vladmir Stenberg (1900-1933, 1899-1982). Esses artistas se reuniram durante os debates teóricos conduzidos no âmbito do Grupo de Análise Objetiva do INKhOUK (entre janeiro e abril de 1921), que versavam a respeito da distinção entre "composição" e "construção".

${ }^{60}$ ALBERA, François, Op. Cit., p. 167.
} 


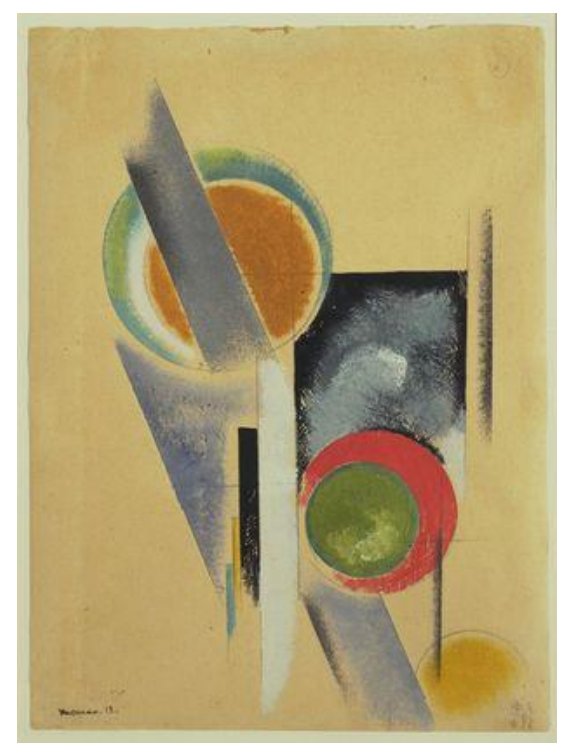

Composition, 1919

Aleksandr Rodchenko. Gouache on paper, $121 / 4 \mathrm{x}$ 9" $(31.1 \times 22.9 \mathrm{~cm})$.

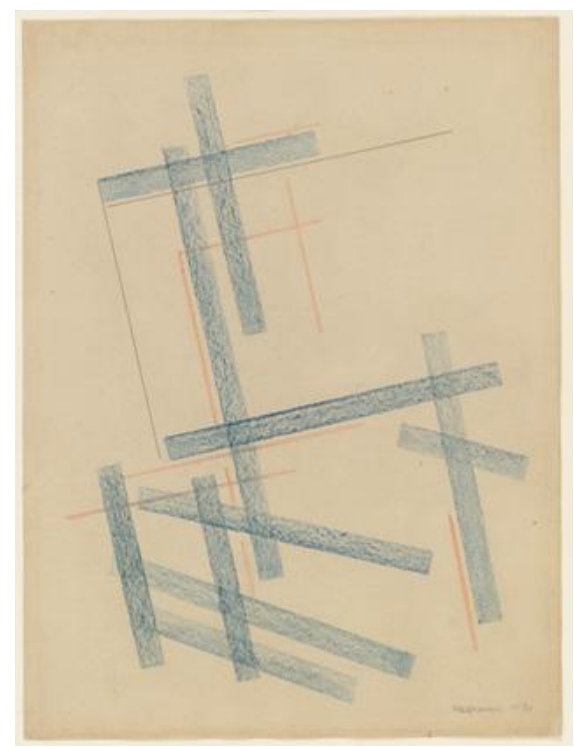

Line Construction, 1921

Aleksandr Rodchenko. Crayon on paper, $14 \times 10$ $1 / 2 "(35.6 \times 26.7 \mathrm{~cm})$.

Segundo as perspectivas apresentadas durante os debates sobre as noções de composição e construção, pode-se entender a noção de construção como um método que tinha por objetivo utilizar os materiais constituintes da obra (neste caso, materiais industriais: o vidro, o metal, a pedra, etc.) de modo a produzir obras que respeitassem a especificidade dos materiais componentes. A concepção de construção estava vinculada à idéia do uso da tecnologia e da engenharia, e os trabalhos pautados por tal noção se caracterizavam pela precisão no trato dos materiais que constituíam as obras, pela clareza da organização dos aspectos formais e, conseqüentemente, pela ausência de elementos decorativos ou supérfluos. Sobre este ponto, Rodchenko afirmou em 1921, no seu programa de aula para o Vkuthemas (Vyshie Gosudarstviennye Khudojestvenno-Tekhinicheskie Masterskie - Ateliê Superior Estatal Técnico-Artístico), que a "CONSTRUÇÃO - é a organização de 
elementos [...] e a condição contemporânea para a ORGANIZAÇÃo e uso utilitário do material". ${ }^{61}$ A perspectiva de Rodchenko sobre a noção de construção contrapunha-se radicalmente à idéia de representação, própria da pintura figurativa e de suas regras de composição. ${ }^{62}$

A fim de atribuir a qualidade de construção aos seus trabalhos, os artistas construtivistas foram progressivamente renunciando à pintura abstrata e optando por trabalhar com materiais industriais (vidro, metal, etc.). Com efeito, tal tendência pôde ser notada nas obras dos artistas que participaram da Segunda Exposição de Primavera do OBMOKU (também conhecida como III Exposição do OBMOKU), inaugurada em 22 de maio de 1921. As formas das esculturas expostas mostraram uma forte relação com elementos formais oriundos da tecnologia industrial (estruturas provenientes de maquinário fabril, metalúrgico, etc.). Os irmãos Stenbergs, por exemplo, criaram formas esqueléticas a partir de materiais como vidro, metal e madeira, evocando estruturas que lembravam pontes e guindastes. Nessa mesma exposição, Rodchenko mostrara uma série de construções suspensas, moldadas a partir do uso de equações matemáticas - formas concêntricas, cortadas a partir de um único plano que, ao ser rotado, criava uma forma geométrica em três dimensões. ${ }^{63}$

\footnotetext{
${ }^{61}$ RODCHENKO, Alexandr, "Construction Is a Contemporary Worldview", Jamey Gambrell (transl.), in LAVRENTIEV, Alexander (Org.), Alexandr Rodchenko: Experiments for the Future, New York, The Museum of Modern Art, 2005, p. 142.

${ }^{62}$ GOUGH, Maria, Op. Cit., p. 25.

${ }^{63}$ Ver KIAER, Christina, "Rodchenko in Paris", in October, Vol. 75, (Winter, 1996), pp. 3-35.
} 


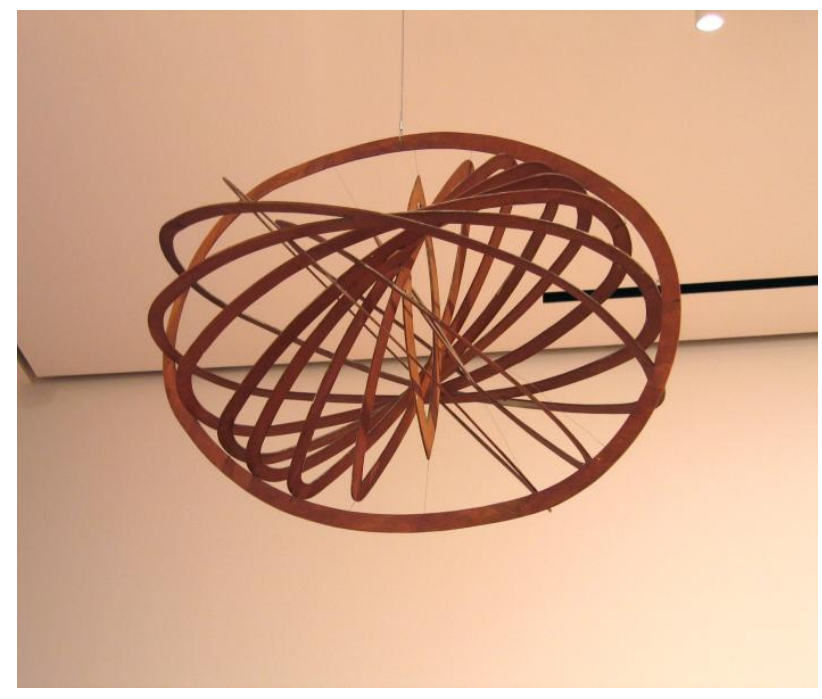

Spatial Construction n. 12, 1920

Aleksandr Rodchenko. Plywood, open construction partially painted with aluminum, paint and wire.

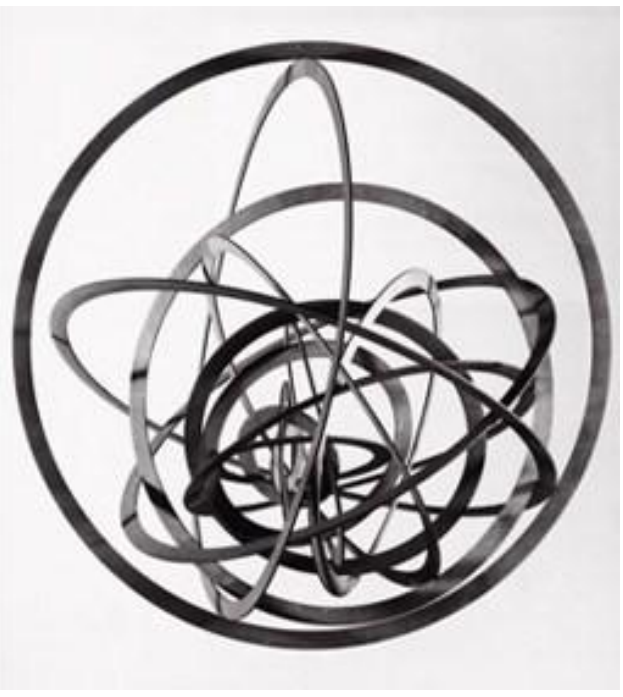

Hanging Spatial Construction n. 9, 1920-1921

Alexandr Rodchenko. Plywood of peach-tree, 90 × 80 x $85 \mathrm{~cm}$, Galerie Gmurzynska Zug.

No âmbito do teatro, as experiências visuais bidimensionais e tridimensionais de alguns artistas foram sendo também adotadas pelo teatro de vanguarda russo. Como exemplo, pode-se citar a concepção cenográfica de Lyubov Popova (1889-1924) para a produção de O Magnânimo Cuco, de Vsevolod Meyerhold (1874-1940). No cenário proposto por Popova, uma miscelânea de fragmentos cenoplásticos - tais como plataformas, portas giratórias, escadas, andaimes e rodas (que giravam em velocidades diferentes) - visavam recriar um ambiente fabril no qual se desenrolava a trama da peça. A artista também trabalhou nos figurinos da peça, desenvolvendo trajes semelhantes a macacões e roupas de produção, concebidos para facilitar os movimentos dos atores. 


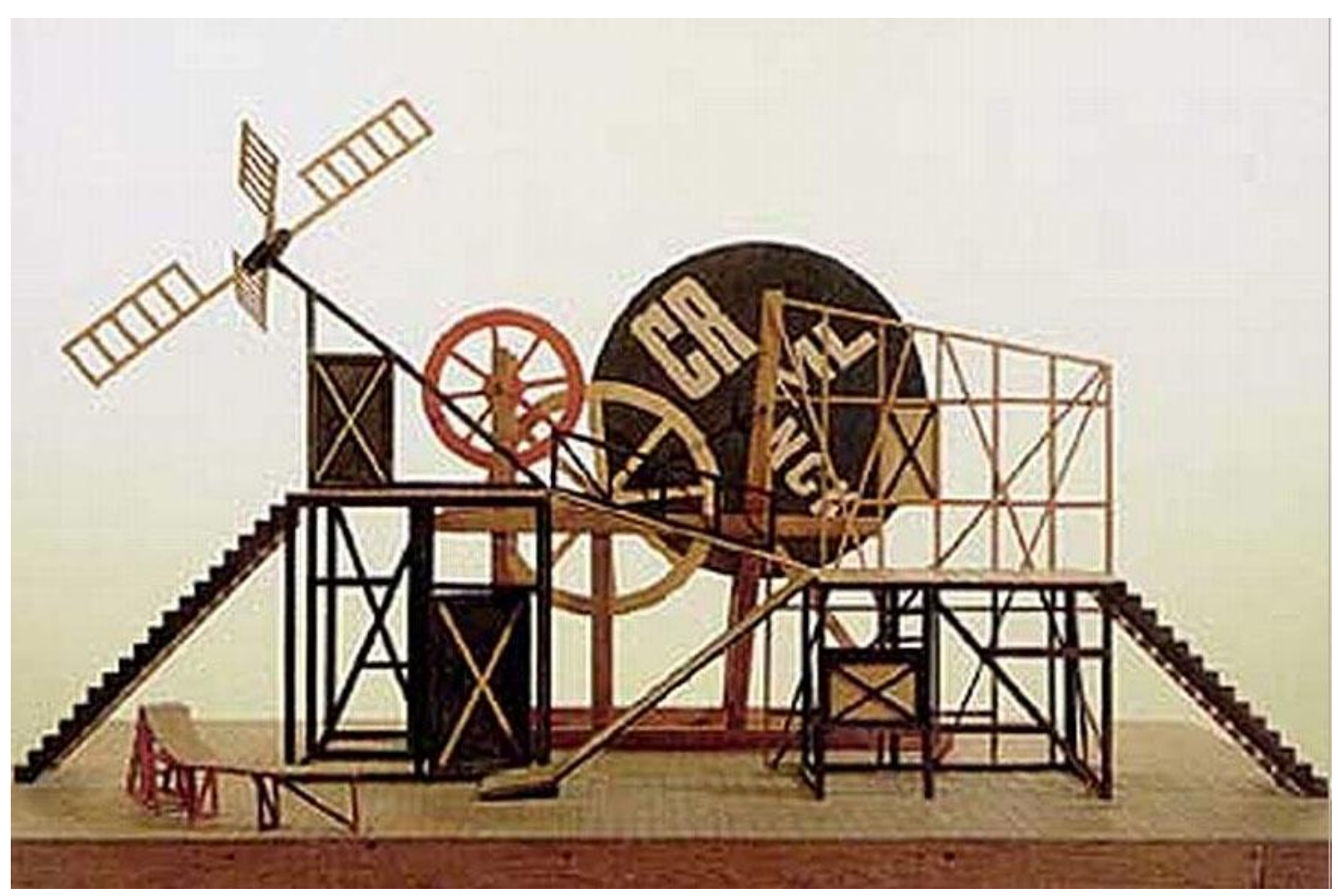

Liubov Popova's Scenic Model for Magnanimous Cuckold, Actors' Theatre (Meyerhold's Workshop), 1922

Wood, metal, gouache, $135.5 \times 75.3 \times 61.5 \mathrm{~cm}$. This model was produced in 1974 for the Meyerhold Exhibition at the Bakhrushin Museum by Natalia Zaitseva.

Paralelamente às atividades teóricas, os construtivistas formularam e desenvolveram sua metodologia de design dentro da Vkuthemas, escola que fora criada no final de 1920 , com o objetivo de formar profissionais altamente qualificados (com formação artística) para o setor da produção industrial. 0 corpo docente do instituto incluía nomes de peso da arte de vanguarda russa, tais como Stepanova, Vesnin, Klucis, Tatlin e El Lissitzky - do último, vale ressaltar que sua obra somente adquiriu um caráter mais próximo da noção de construção, após seu retorno da Alemanha, em 1925. ${ }^{64} \mathrm{Na}$ Vkhutemas, novos artistas estavam sendo treinados para se tornarem artistas-construtores trabalhadores versados na manipulação de diversos materiais industriais, e

\footnotetext{
${ }^{64}$ Sobre este ponto ver BOIS, Yve-Alain, HUBERT, Christian (trad.), "El Lissitzky: Reading Lessons", in OCTOBER 11, Cambridge, MA, MIT Press, Winter 1979, pp. 113-128.
} 
cuja formação seria tanto artística quanto tecnológica. ${ }^{65}$ Tal atitude artística, desenvolvida no seio dos debates do INKHOUK e amplamente difundida no Vkuthemas, foi um produto da atmosfera utópica gerada pela Revolução e por fatores de ordem social do período da Guerra Civil (1918-21). Depois de 1917, a indústria e as máquinas passaram a ser vistos como as características essenciais da classe trabalhadora e, portanto, da nova ordem comunista. ${ }^{66} \mathrm{Em}$ termos práticos, o desenvolvimento industrial também foi considerado pelas autoridades do Estado como a chave do progresso político e social. Assim, a máquina se constituíra como uma metáfora para a nova cultura em construção, como uma representação dos meios práticos necessários para a reconstrução da economia: um prelúdio para o estabelecimento do comunismo.

\footnotetext{
${ }^{65}$ De acordo com o historiador Jair Miguel, o Vkuthemas, ao ser criado tinha como missão básica prover o estado soviético de um grupo diferenciado de artistas, que atuariam tanto na criação de obras, quanto no setor produtivo (design industrial, tipografia, etc.) e na docência. [Tratava-se] de uma instituição de formação superior e técnica, uma continuação dos SVOMAS (Ateliês Artísticos Livres Estatais - Gosudarstvenneye Svobodnye Khudozhestvennye Masterkie - 1918-1920) e das antigas escolas de arte [do período czarista]. [...]. A criação do Vkhutemas, [colocara] Moscou como centro do desenvolvimento artístico da Rússia revolucionária [...]. Em pouco tempo, as principais forças do pensamento estético-artístico do país confrontavam-se para resolver o modelo didático-pedagógico de uma instituição diferenciada. Como em um mesmo lugar as artes 'puras' iriam dividir lugar com as artes 'aplicadas' e [também] com novas 'artes industriais', 'artistas de cavalete' e construtivistas começaram a [disputar as disciplinas do ciclo básico da instituição]". Ver MIGUEL, Jair Diniz, Arte, Ensino, Utopia e Revolução: Os Ateliês Artísticos Vkhutemas/Vkhutein (Rússia/URSS, 1920-1930), Tese de Doutorado, São Paulo, Universidade de São Paulo, 2006.

${ }^{66}$ Segundo a perspectiva de Briony Fer, a metáfora da construção do socialismo foi um dos temas recorrentes nos escritos de Lênin. Para a historiadora, tal metáfora, evocada pelo discurso político da época, remetia à idéia da "construção" de um novo sistema de organização social, que incorporaria o trabalhador de maneira mais eficiente à dinâmica produtiva da sociedade. Tendo em vista as afirmações sobre a relação entre arte e política, presentes nos manifestos construtivistas entre 1921-1923, pode-se considerar que as proposições construtivistas sobre a reformulação do campo artístico, e sua associação com a esfera tecnológica, estavam intimamente ligadas ao projeto leninista de reconstrução do modo de vida do trabalhador soviético. Sobre este ponto ver FER, Briony, "Metaphor and Modernity: Russian Constructivism", in Oxford Art Journal, Vol. 12, No. 1 (1989), pp. 21-22.
} 


\section{II: Produtivismo: a produção artística em diálogo com as necessidades da produção industrial}

Em meados de 1921, Osip Brik (1888-1945), o crítico literário e teórico do campo das artes plásticas, liderou, na função de presidente do Grupo de Análise Objetiva do INKHOUK, a implementação da plataforma produtivista no programa de trabalho do instituto. Os principais teóricos que elaboraram o produtivismo junto com Brik - Boris Kushner (1888-1937), Boris Arvatov (18961940) e Sergei Tret'iakov (1892-1937) - consideravam que os conhecimentos dos artistas, inseridos no contexto social revolucionário, precisavam ser associados às competências técnicas dos trabalhadores e também à disciplina da produção industrial. Segundo Arvatov, "a funcionalidade social e técnica [era] [...] o único critério para medir uma atividade artística, ou seja, para a invenção de novas formas. [...] Assim sendo, [...] a introdução da arte na atividade industrial não [era] um meio de salvação da arte, de estetização do objeto, mas de fomento da produção industrial em si”. Nesse sentido, as experiências formais levadas a cabo pelos artistas construtivistas, no período entre 19201921 (os primeiros trabalhos de Naum Gabo podem ser citados como exemplo), resultavam em objetos que estavam dissociados da esfera produtiva. Para Arvatov assim como para outros produtivistas (Tret'iakov e Brik), tais obras constituíam uma forma de produção artística fetichizada, uma vez que seu caráter construtivo não dialogava com as necessidades da produção industrial. Deste modo, os experimentos formais da primeira fase do 
construtivismo (1920-1921) consistiram numa forma de realização não funcional. $^{67}$

A artista revolucionário deveria se tornar um "artista-engenheiro". O objetivo maior da plataforma produtivista era transformar a fábrica em um centro de pesquisa, estimulando a criatividade dos trabalhadores, a fim de reformular as práticas coletivas do setor produtivo. A arte seria capaz de oferecer, segundo essa proposta, uma verdadeira transformação nas relações de produção e nas relações sociais. A figura do artista-engenheiro foi pensada, nesse contexto, como a de um trabalhador especializado, incumbido de reconfigurar os meios de produção, a fim de criar novos objetos dissociados dos modelos de produção capitalistas.

Na medida em que as idéias produtivistas ganhavam força nos debates do instituto, os artistas e dirigentes que discordavam da recém criada plataforma foram abandonando a instituição. Kandinskii, em 1921, renunciou à direção do INKHOUK, poucos meses antes de partir para o exílio na Alemanha. Por sua vez, Gabo, que participara com afinco das discussões do Grupo de Análise Objetiva - construtivista "declarado" - também procurou exílio na Alemanha. Malevitch, um dos principais ícones do Suprematismo, fixou residência em Petrogrado, passando a atacar em seus escritos tanto o construtivismo quanto o produtivismo.

Nesse sentido, é razoável considerar que o construtivismo (desenvolvido durante 1921) e o produtivismo (de 1922 em diante) concebem a práxis artística de modos distintos: "A partir desse contexto, pode-se definir o

\footnotetext{
${ }^{67}$ ARVATOV, Boris, Op. Cit., pp. 78-79.
} 
construtivismo como 'método artístico' (adotado por Tatlin, Rodtchenko, Popova, etc.) 'que visa dar forma a objetos realmente funcionais', e o produtivismo como 'teoria sociológico-estética que prevê um impulso e um domínio das artes vinculado à produção de objetos socialmente úteis, considerando a arte contemporânea uma forma particular de produção' (Arvatov, Gan, Tret'iakov, Brik, etc.)". ${ }^{68}$

O Clube Dos Trabalhadores, de Rodchenko, foi um projeto de construção funcional, elaborado para a Éxposition Internationale des Arts Décoratifs et Industriels Modernes (realizada em Paris em 1925) e talvez tenha sido uma das experiências mais bem sucedidas da metodologia construtivista, que visava aliar o conhecimento técnico da indústria ao campo artístico. É importante salientar que os "Clubes de Trabalhadores" (associações culturais fomentadas pelo governo bolchevique, nas quais trabalhadores encontravam um espaço para o estudo e a recreação) eram tidos como uma peça importante para o desenvolvimento do estado soviético, tendo em vista seu papel como agente politizador, além de ser um tipo de instituição voltada para a camada menos escolarizada da população. Rodchenko, em seu projeto, padronizou os elementos que compunham o mobiliário e compôs uma economia espacial rigorosa em termos de material e métodos de produção. As cadeiras, por exemplo, tinham uma base de sustentação simples (três apoios) e foram pensadas para serem feitas de madeira - um material barato e abundante na Rússia da década de 1920. Nesse sentido, o mobiliário respondia aos problemas contemporâneos relativos às condições materiais da época, já que os itens que compunham as áreas de estudo e de lazer foram dispostos para

68 STRIGALEV, Anatolii A, "Art et production", in Paris-Moscow, 1900-1930, Paris, Centre Pompidou, 1979, p 262-264, apud ALBERA, François, Op. Cit., p. 168. 
fins de economia de espaço, e concebidos para serem dobráveis, facilitando o armazenamento e a organização.

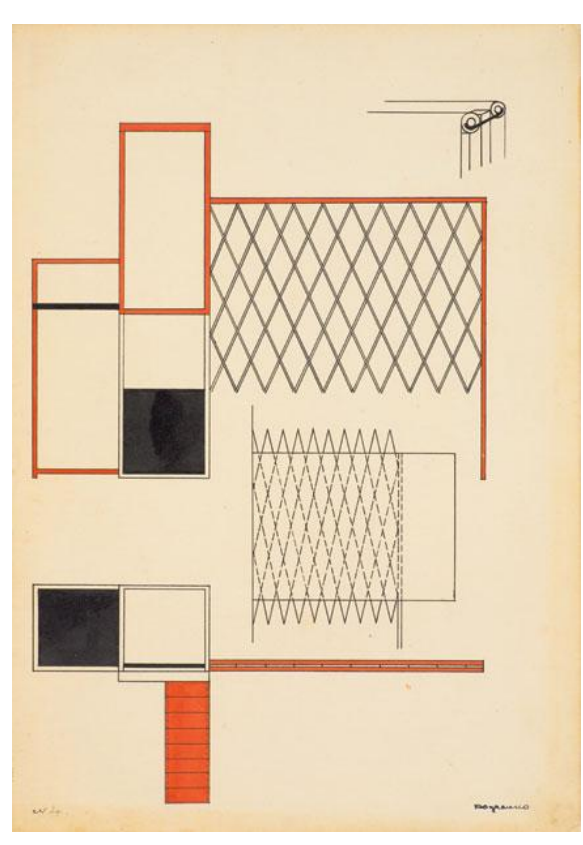

Aleksandr Rodchenko,

Design for a collapsible rostrum for the USSR Workers club, exhibited at the

Exposition Internationale des Arts Décoratifs et

Industriels Modernes, Paris

1925, Private collection, A

Rodchenko \& V Stepanova

Archive / DACS 2009

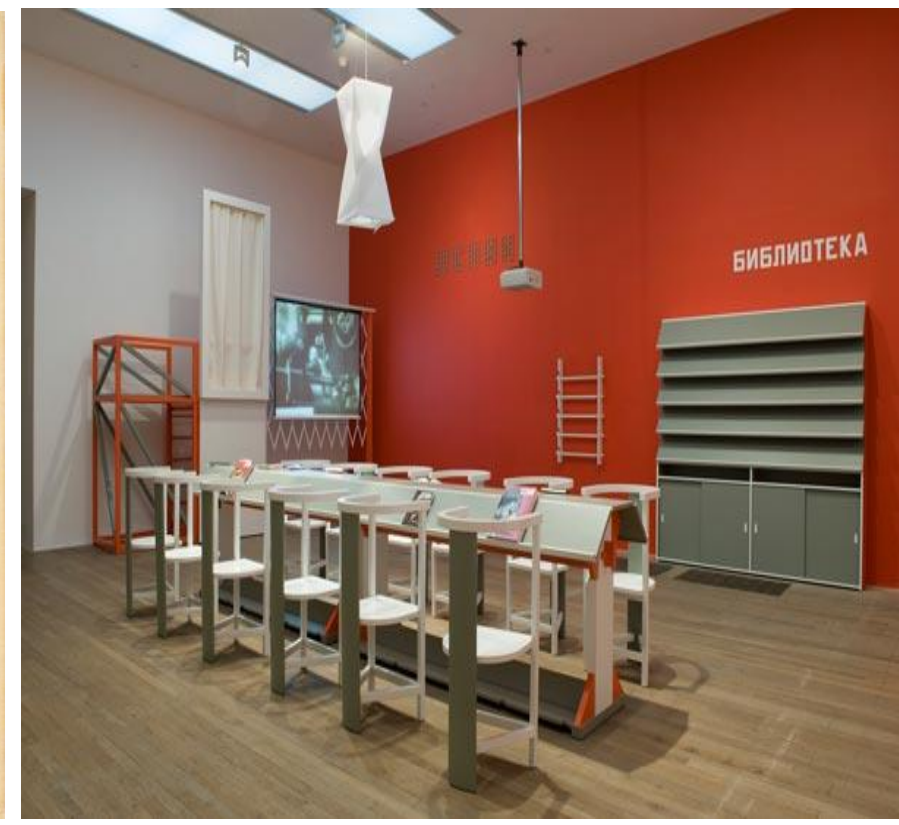

Tate installation shots of the (Rodchenko's) workers club, Photo: Andrew Dunkley and Marcus Leith, Tate Museum, 2009.

De acordo com a perspectiva da historiadora Christina Kiaer, o clube de Rodchenko foi um exemplo da maneira como o construtivismo "imaginou uma forma de modernidade, que abraçou a tecnologia e a eficiência dos sistemas de regulamentação da vida urbana - a produção em massa, os transportes públicos motorizados, os sistemas de esgoto encanados - todavia, sem conceber a forma-mercadoria, que manchara a transparência [dos objetos tecnológicos e funcionais] com as associações e as fantasias eróticas 
intermináveis da moda [e da subjetividade consumista, própria do capitalismo]" ${ }^{69}$ Nesse sentido, a reorganização da vida cotidiana, proposta pela dinâmica construtiva do Clube dos Trabalhadores, de Rodchenko, era radicalmente oposta às relações de consumo presentes em Moscou, nos primeiros anos da NEP, e também em Paris. "O clube não foi simplesmente um show de design, inventado por Rodchenko para impressionar os espectadores parisienses por meio do ascetismo comunista". ${ }^{70} \mathrm{Na}$ URSS, ele fora empregado pela Proletkult ${ }^{71}$ de Moscou, tornando-se objeto de estudo das oficinas de carpintaria, que se propunham a revitalizar os clubes de trabalhadores da capital, todavia, tais projetos infelizmente contavam "sempre com os financiamentos mais apertados que a economia da NEP poderia oferecer". ${ }^{72}$

\footnotetext{
${ }_{70}^{69}$ KIAER, Christina, "Rodchenko in Paris", in October, Vol. 75, The MIT Press, 1996, p. 5.

${ }_{71}^{70}$ Idem, Loc. Cit.

71 Proletkult é uma abreviação para a expressão "Proletarskaya kultura" (пролетарская культура - cultura proletária). Foi um movimento cultural ativo na União Soviética entre os anos de 1917 e 1925. Criada sob a liderança do Alexander Bogdanov (1873-1928) e Anatólií Lunachárskií (1875-1933), a Proletkult tinha como objetivo principal difundir atividades culturais entre os trabalhadores e, principalmente, a experimentação artística, visando à formulação de uma "cultura proletária", dissociada dos valores da cultura burguesa. De acordo com seus líderes, a arte não devia se restringir somente à tarefa da representação do ponto de vista de uma determinada classe social, ela deveria tornar-se uma prática útil que pudesse colaborar para a organização política dos trabalhadores. "K sozyvu Vserossiiskoi kul'turno-prosvetitel'noi konferentsii rabochikh organizatsii," Proletarskaia kul'tura, no. 1 (1918), p. 27, Apud MALLY, Lynn, Culture of the Future: The Proletkult Movement in Revolutionary Russia, Berkeley, University of California Press, 1990, p. 43.

${ }^{72}$ KIAER, Christina, Op. Cit., p. 33.
} 

encenado"

A temática mais abordada pelo discurso dos artistas e teóricos construtivistas sobre o cinema dizia respeito à sua capacidade de se adaptar às tarefas sociais pertinentes à revolução: agitação e disseminação de conhecimento. ${ }^{73}$ Nesse sentido, as proposições da maioria dos autores ligados à vanguarda que se debruçaram sobre 0 assunto discorriam principalmente sobre a questão do "material" a ser trabalhado no cinema (os assuntos com os quais os filmes lidavam). Essa questão levou a uma das principais divergências no debate construtivista sobre o cinema soviético na década de 1920, que se baseava na oposição entre o cinema "encenado" e o cinema "não encenado" (sendo ambos entendidos como gêneros cinematográficos: cinema ficcional e cinema documental, respectivamente). Em certa medida, pode-se dizer que esse debate não esgotava a variedade dos trabalhos cinematográficos dos cineastas ligados à vanguarda, principalmente Kuleshov (1899-1970), Eisenstein (1898-1948) e Vertov (1896-1954). ${ }^{74}$ Todavia, a questão do uso (ou

\footnotetext{
${ }^{73}$ KOLCHEVSKA, Natasha, Lef and Developments in Russian Futurism in the 1920's, PhD Thesis, Berkley, University of California, 1980, p. 254.

${ }^{74}$ Grosso modo, pode-se dizer que os cineastas construtivistas (Eisenstein, Vertov, etc.) - cada um a seu modo - defendiam uma maneira de fazer cinema, ligada intimamente com o contexto social revolucionário. Tanto Eisenstein quanto Vertov e Pudovkin, por exemplo, tinham como elemento central em seus processos construtivos a necessidade de um princípio organizacional que pudesse concatenar os fragmentos cinematográficos, de modo a tornar as seqüências mais inteligíveis para o público. Além disso, eles defendiam que os temas e assuntos abordados pelos filmes soviéticos, ligados ao contexto da revolução, deveriam ser construídos a partir de cenas (ou fragmentos documentais, no caso de Vertov e Shub) que estabelecessem relações com aspectos sociais e/ou históricos do contexto revolucionário e do cotidiano dos trabalhadores (em outras palavras, a partir de uma perspectiva "factográfica", uma construção cinematográfica mediante fatos). Nesse sentido, é possível afirmar que a polêmica entre esses cineastas se caracterizava pela divergência de estratégias formais que cada um utilizava para atingir o público soviético (operários e camponeses) e disseminar idéias ligadas à revolução. Sobre este ponto ver STOLLERY, Martin, "Eisenstein, Shub and the gender of the author as producer", in Film History, Vol. 14, No. 1, Bloomington, Indiana University Press, 2002, pp. 8799. Ver também KOLCHEVSKA, Natasha, Op. Cit., pp. 254-266.
} 
não) de atores no cinema revolucionário soviético (isto é, nos filmes que tinham em seu conteúdo questões relativas à história do processo histórico revolucionário e às tarefas sociais mais urgentes da URSS) polarizou o debate travado pelos construtivistas (Arvatov, Tret'iakov, Gan) e pelas publicações que trataram do cinema russo e seus temas (KINO-fot, LEF, ARK).$^{75}$

É importante notar que durante o período czarista, não houve o desenvolvimento de uma vanguarda cinematográfica que estabelecesse um contraponto forte à filmografia produzida segundo o modelo dos estúdios franceses (principais investidores da indústria cinematográfica russa). ${ }^{76} \mathrm{O}$ cinema apenas se tornou, efetivamente, objeto de interesse para os artistas e teóricos que fomentaram o construtivismo por volta do ano de 1922. Desde 1913, Maiakovski já escrevera sobre o cinema, no entanto, somente a partir de sua combinação com o teatro. Para o poeta, o registro fílmico se apresentava como um meio técnico que desafiava a arte teatral, mas também como instrumento capaz de liberar o ator das restrições físicas da atuação em palcos. Em Urichtozhenie kinematografom "teatra" kak priznak vazrozhdeniya teatral'nogo iskvusstva (A Destruição do "Teatro" pelo Cinema como um Sinal da Ressurreição da Arte Teatral), ${ }^{77}$ publicado no mesmo ano, o poeta futurista enfatizava o caráter de reprodução mecânica do cinema, considerando-o uma ferramenta à criatividade artística: "o artista continua a ser o líder, o cinema meramente [...] arquiva os atores do palco, tendo com ele o que dele é reconhecidamente uma cópia, mas uma cópia dos grandes momentos de

\footnotetext{
${ }^{75}$ ALBERA, François, Op. Cit., p. 218-221

${ }^{76}$ CHRISTIE, Ian, "Introduction 1896-1921", in TAYLOR, Richard, Op. Cit., p. 19.

${ }^{77}$ MAYAKOVSKY, Vladimir, "Destruction of 'Theater' by Cinema as a Sign of the Resurrection of Theatrical Art", in TAYLOR, Richard, Op. Cit., pp. 34-35.
} 
criatividade" ${ }^{78}$ Tal posição era ecoada nas posturas de Meyerhold e Chklóvski sobre o tema. Em 1915, Meyerhold afirmava que sua "atitude com respeito ao cinema [era] extremamente negativa" e considerava que o meio fílmico era "completamente impróprio" para os "artistas do drama". ${ }^{79}$ Chklóvski, por sua vez, também não julgava que o cinema pudesse se constituir como uma arte autônoma, posto que para ele, "o mundo da arte era o mundo da continuidade" e o cinema era um meio caracterizado pela descontinuidade. ${ }^{80}$

Com o advento da Revolução de Outubro e com o aparecimento dos primeiros trabalhos de Vertov, Shub e Kuleshov (entre os anos de 1917 e 1923), tais posições dos artistas e críticos ligados à vanguarda russa (futurismo e escritores ligados à escola formalista, principalmente) foram gradualmente sendo revistas. Maiakovski passou a apoiar o cinema fundado no registro documental e no trabalho com os "materiais reais" ${ }^{81}$ - cenas retiradas de improviso dos fatos mais recentes, concernentes aos eventos políticos revolucionários e aos aspectos mais corriqueiros do cotidiano dos trabalhadores (os filmes de atualidades de Vertov e Shub) - e a se contrapor aos filmes russos ficcionais. ${ }^{82}$ Chklóvski, em Semantika Kino (A Semântica do Cinema), artigo publicado em 1925, ao contrário de Maiakovski e Alexei Gan, atacou a teoria cinematográfica de Vertov, ${ }^{83}$ admitindo o caráter artístico do

\footnotetext{
${ }^{78}$ Idem, p. 34.

${ }^{79}$ MEYERHOLD, Vsevolod, "On Cinema", in TAYLOR, Richard, Op. Cit., p. 39.

${ }^{80}$ CHKLOVSKI, Viktor, La Résurrection du mot et Littérature et cinématographe, Paris, Champ Libre, 1985, p. (a confirmar), apud ALBERA, François, Op. Cit., p. 208. Segundo Galin Tihanov, a concepção de arte desenvolvida por Chklovski nos primeiros anos da década de 1910 primava pela continuidade dos elementos que compunham o trabalho artístico. Sobre este ponto ver TIHANOV, Galin, "The Politics of Estrangement: The Case of the Early Shklovsky", in Poetics Today, Vol. 26, No. 4, Duke University Press, 2005, pp. 665-696.

${ }^{81}$ MAYAKOVSKY, Vladimir, "Cinema and Cinema", in TAYLOR, Richard, Op. Cit., p. 75.

${ }^{82}$ MAYAKOVSKY, Vladimir, "On Cinema, in TAYLOR, Richard, Op. Cit., p. 174-175.

${ }^{83}$ Para Chklóvski, "os fragmentos usados [por Vertov] são tradicionais [do ponto de vista da arte cinematográfica]. [...] O material cru do Cine-Olho é filmado sem nenhuma atenção para a
} 
cinema. Segundo o lingüista, "o cinema é a arte do movimento semântico" e "o material primário do cinema não é o objeto filmado, mas um método determinado de filmar o objeto". ${ }^{84}$

De acordo com a perspectiva de Albera, Proekt Inzhenera Praita ( $O$ projeto do Engenheiro Prite), de Lev Kuleshov, lançado em 1917, foi um dos primeiros filmes russos a ter uma ligação mais consistente com os elementos de construção cinematográficos oriundos do cinema americano, que posteriormente foram assimilados pelo cinema construtivista. ${ }^{85}$ Tratava-se de um filme de aventura, cuja narrativa girava em torno do roubo de uma invenção hidroelétrica de um engenheiro, e se diferenciava dos outros nos quais Kuleshov havia participado. ${ }^{86}$ A ênfase que o diretor deu aos objetos mecânicos e à inserção de planos documentários sobre características do de uma hidroelétrica projetada pelo engenheiro se contrapunha (segundo o próprio

semântica do cinema e os objetos filmados, portanto, parecem estar desconectados entre si [...] Em seus quadros, os objetos são empobrecidos porque não há uma atitude parcial (no sentido artístico da palavra) para com o objeto". SHKLOVSKY, Viktor, "Semantics of Cinema", in TAYLOR, Richard, Op. Cit., pp. 132-133.

${ }^{84}$ Idem, p. 133.

${ }^{85}$ É importante ressaltar a maneira pela qual os cineastas construtivistas analisaram as técnicas de construção cinematográficas dos cineastas americanos (sendo que D. W. Griffith fora a principal referência). Vertov, em My. Variant manifesta (Nós. Uma Versão de um Manifesto), de 1922, afirma que o "Cine-Olho agradece o cinema de aventura americano [...] pelas suas rápidas mudanças de plano e seus close-ups". Contudo, o documentarista também considerava que o cinema estadunidense era "desordenado: infundado em um estudo preciso do movimento" (VERTOV, Dziga, "We. A Version of a Manifesto", in TAYLOR, Richard, Op. Cit., p. 69). Por sua vez, Eisenstein, em 1924, afirmara que "o fracasso da maioria dos filmes russos derivou do fato de que seus diretores não souberam como construir esquemas de atrações de maneira consciente [...]". Segundo o diretor, "os filmes de Griffith [...] poderiam ensinar muito aos russos sobre a montagem, apesar de seu propósito social hostil [para o cinema russo]" (EISENSTEIN, Sergei M., "The Montage of Film Attractions", in S. M. Eizenshtein Writings, 1922-34, TAYLOR, Richard (Ed. e trad.), London, BFI Publishing, 1987, pp. 44). Sobre esta questão ver BORDWELL, David, "The Idea of Montage in Soviet Art and Film", in Cinema Journal, Vol. 11, No. 2, Austin, University of Texas Press on behalf of the Society for Cinema \&amp; Media Studies, 1972, pp. 9-17.

${ }^{86}$ Tendo em vista as considerações sobre a composição cinematográfica formuladas por Kuleshov em Iskusstvo svetotvorcherstva (A Arte do Cinema), artigo publicado em 1918, é possível afirmar que $O$ projeto do Engenheiro Prite marcou a ruptura do cineasta com os trabalhos de Yevgeni Bauer (1865-1917) - um dos principais diretores do cinema russo no período czarista (1898-1917) e professor de Kulshov. KULESHOV, Lev, "The Art of Cinema", in TAYLOR, Richard, Op. Cit., p. 45. 
Kuleshov) aos temas de boa parte dos filmes russos da época. ${ }^{87}$ Para Albera, "O filme - ao menos o que resta dele - caracteriza-se por uma mistura de códigos e estilos mais griffithianos do que "futurista". Mas a decupagem bastante funcional do início (primeiro plano de um sino, um apito de locomotiva, um relógio, um relógio de pulso que orquestra a partida de um trem e um desencontro), o recurso às ações paralelas, ao flashback, tudo isso é próprio de um cineasta que em seus primeiros artigos exprime a primazia da montagem no cinema e o caráter secundário da interpretação devido à própria tecnologia do filme". 88

Montagem é para o cinema o que a composição pela cor é para a pintura ou a seqüência harmônica é para a música. Na cena dramática, o método de interpretar uma produção teatral reside no ator que expressa a idéia teatral por meio da vontade criativa do diretor e dá-lhe uma forma individual. No cinema, devido ao seu elevado componente tecnológico incomum - a quintessência da máquina e da eletricidade - e devido ao surpreendente significado da montagem, $\mathrm{o}$ ator aparece um segundo lugar. ${ }^{89}$
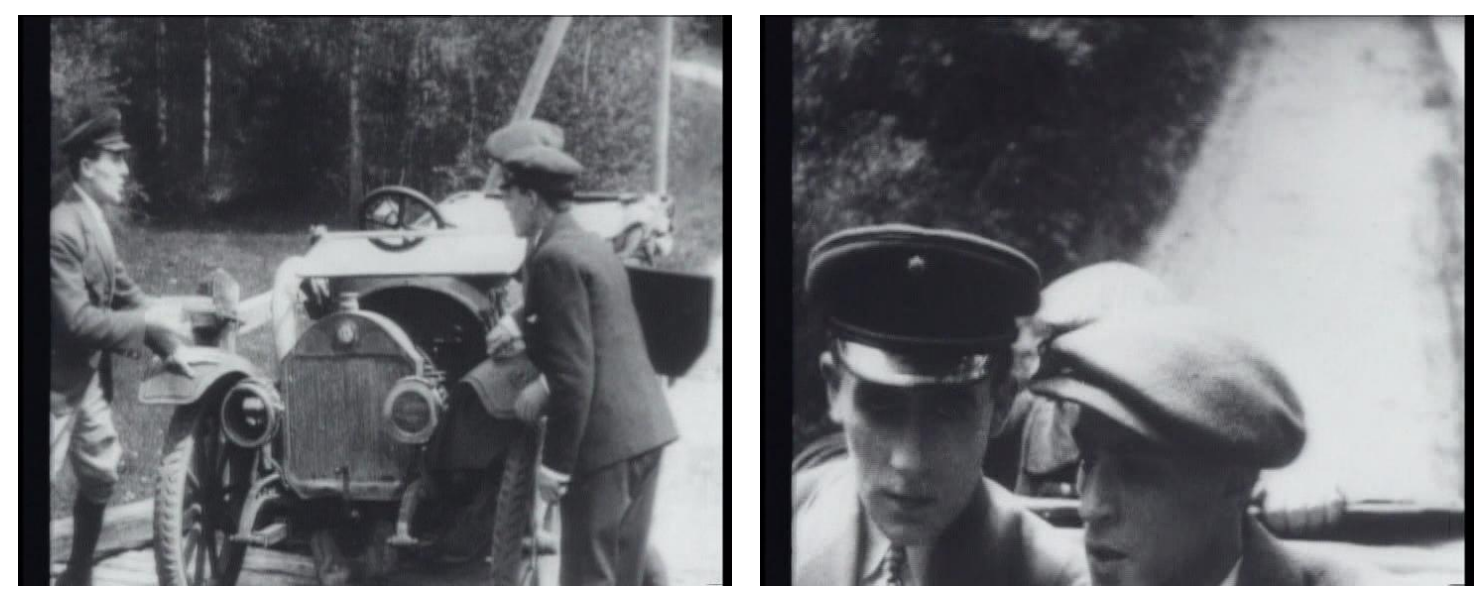

Proekt Inzhenera Praita, URSS, 1917, Dir: Lev Kuleshov.

\footnotetext{
87 Idem, Loc. Cit.

${ }^{88}$ ALBERA, François, Op. Cit., p. 209.

89 KULESHOV, Lev, "The Art of Cinema”, in TAYLOR, Richard, Op. Cit., p. 46.
} 
Entretanto, apesar da ênfase de Kuleshov na questão da primazia da montagem na composição $0^{90}$ fílmica, é necessário ressaltar que se tratava de um período do cinema russo (1915-1919) no qual a maioria dos cineastas tentava encontrar a especificidade do cinema a partir das técnicas de encenação teatral e do ritmo no interior do quadro. De certa maneira, a formulação da teoria da montagem de Kuleshov - baseada na experiência teatral da década de 1910 (sendo a mais importante delas a teoria da biomecânica de Meyerhold) - foi uma empreitada artística individual do diretor, que anos depois sofre influência dos princípios construtivistas.

Desse modo, a noção de trabalho cinematográfico para Kuleshov, inicialmente fundada na dinâmica rítmica da encenação (o movimento no interior do filme pensado de maneira análoga ao movimento da coreografia cênica), passou a ser baseada principalmente no estudo das técnicas da montagem fílmica. ${ }^{91} \mathrm{~A}$ aproximação do diretor com os princípios construtivistas pôde ser percebida em Isksstvo, sovremennaya zhizn' i kinematografiya (Arte, Vida Contemporânea e Cinema), artigo publicado em 1922, no primeiro número da revista KINO-fot, organizada por Alexei Gan e dedicada inteiramente a artigos sobre cinema e fotografia. Neste texto, as considerações sobre o meio fílmico apresentadas por Kuleshov e a combatividade de sua argumentação mostrava sua adesão aos princípios do movimento construtivista. O uso de expressões como "método científico" e "material cru" refletiam a preocupação do cineasta em estabelecer uma relação entre as suas técnicas de montagem, desenvolvidas no final da década de 1910, e uma forma de trabalho com o

\footnotetext{
90 "A essência do cinema reside na criatividade do diretor [...]: tudo é baseado na composição." KULESHOV, Lev, "The Tasks of the Artist in Cinema", in TAYLOR, Richard, Op. Cit., p. 41.

${ }^{91}$ KULESHOV, Lev, "Americanism", in TAYLOR, Richard, Op. Cit. pp. 72-73.
} 
cinema, "organicamente conectada com a vida" do período revolucionário soviético, que pudesse refletir "realidade do material cru". ${ }^{2}$

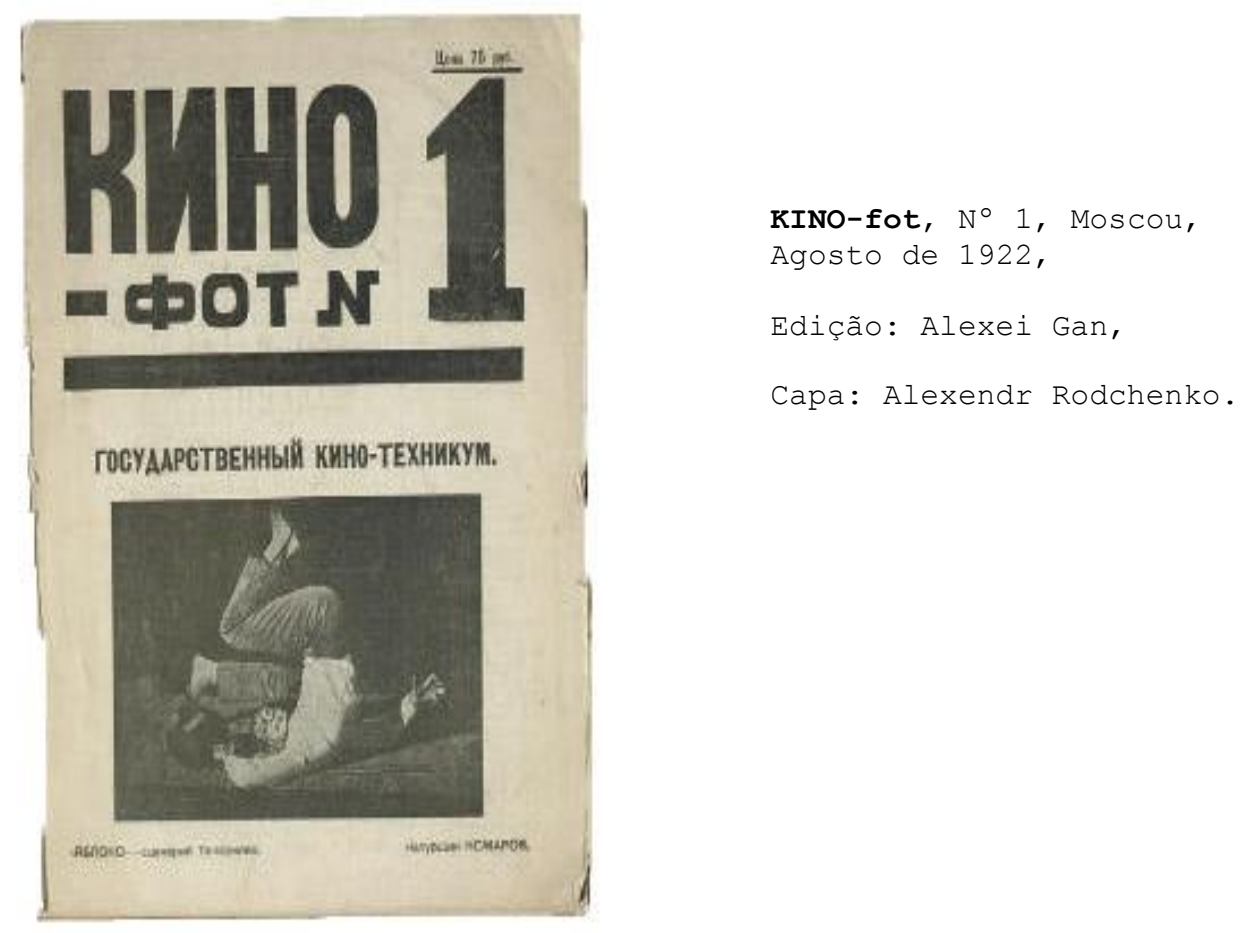

Embora essa temática no discurso de Kuleshov - em Arte, Vida Contemporânea e Cinema - sobre a relação entre o cinema e a vida cotidiana fosse consoante com as posições dos autores participantes da revista KIИOфот (KINO-fot), sua perspectiva a respeito do gênero cinematográfico apropriado às tarefas sociais do cinema divergira em relação à postura de outros cineastas construtivistas, principalmente Vertov. Grosso modo, a kinematografiya (cinematografia) de Kuleshov era contrária "aos filmes psicológicos russos," (anteriores à Revolução de Outubro e fortemente influenciados pelo teatro) e favorável às construções cinematográficas presente

\footnotetext{
${ }^{92}$ KULESHOV, Lev, "Art, Contemporary Life and Cinema", in TAYLOR, Richard, Op. Cit., pp. 68-69.
} 
nos filmes de ação americanos. ${ }^{93}$ Segundo Albera, "a aproximação do diretor com o construtivismo se deu na base do "maquinismo", que inspirava a abordagem do corpo humano, dos movimentos, etc. Mas a sistematização do movimento humano [de Kuleshov] partia de uma segmentação, enquanto os construtivistas mais radicais (Eisenstein, Vertov) propunham a máquina como modelo e postulavam, por conseguinte, uma abordagem inteiramente nova sobre a relação arte-corpo". 94

Em contraposição às propostas de Kuleshov, Vertov, ainda no primeiro número de KINO-fot, publicava seu manifesto My. Variant manifesta (Nós. Uma Versão de um Manifesto), ${ }^{95}$ no qual estabelecia sua oposição aos filmes russos "romanceados" e "teatralizados". Esse manifesto de Vertov, vinculado a seu trabalho prático no campo da filmagem de atualidades, contribuiu para uma das formulações teóricas mais importantes do seu discurso sobre o cinema. Tal proposta estabelecia a oposição entre as noções de kinematograf (o cinema como máquina) e kinematografiya (cinematografia - cinema permeado pelos preceitos construtivistas). ${ }^{96}$

\footnotetext{
${ }^{93}$ Pudovkin afirmava em 1922 que, se os jovens cineastas russos estudassem "os filmes americanos e justapusessem [suas] observações com os resultados das tentativas mal sucedidas, a fim de alcançar uma maior 'especificidade cinematográfica' e não uma reprodução da 'teatralidade' nos filmes, pelo uso dos bem conhecidos métodos dos [...] diretores russos, [eles] não poderiam deixar de valorizar a forte impressão particular deixada pelos filmes que foram conscientemente compostos por uma série de cenas rápidas". KULESHOV, Lev, "Americanism", in TAYLOR, Richard, Op. Cit., p. 73.

${ }^{94}$ ALBERA, François, Op. Cit., p. 211.

${ }^{95}$ VERTOV, Dziga, "We. A Version of a Manifesto", in TAYLOR, Richard, Op. Cit., pp. 69-71.

${ }^{96}$ Embora Vertov considerasse que a proposta do Kino-Glaz fora influenciada pelas estratégias de construção cinematográfica dos "filmes de aventura americanos", ele julgava que o modo como os cineastas americanos filmavam não era fundado em um "estudo preciso do movimento". De modo semelhante à Gan, o documentarista considerava que o cinematógrafo (kinematograf) - o aparato mecânico de registro da arte teatral e dos valores burgueses deveria ser substituído por uma cinematografia (kinematografiya) ligada organicamente à sociedade proletária. Ver VERTOV, Dziga, "We. A Version of a Manifesto", in TAYLOR, Richard, Op. Cit., pp. 69-71. Ver também GAN, Alexei, The Cinematograph and Cinema, in TAYLOR, Richard, Op. Cit., pp. 67-68.
} 


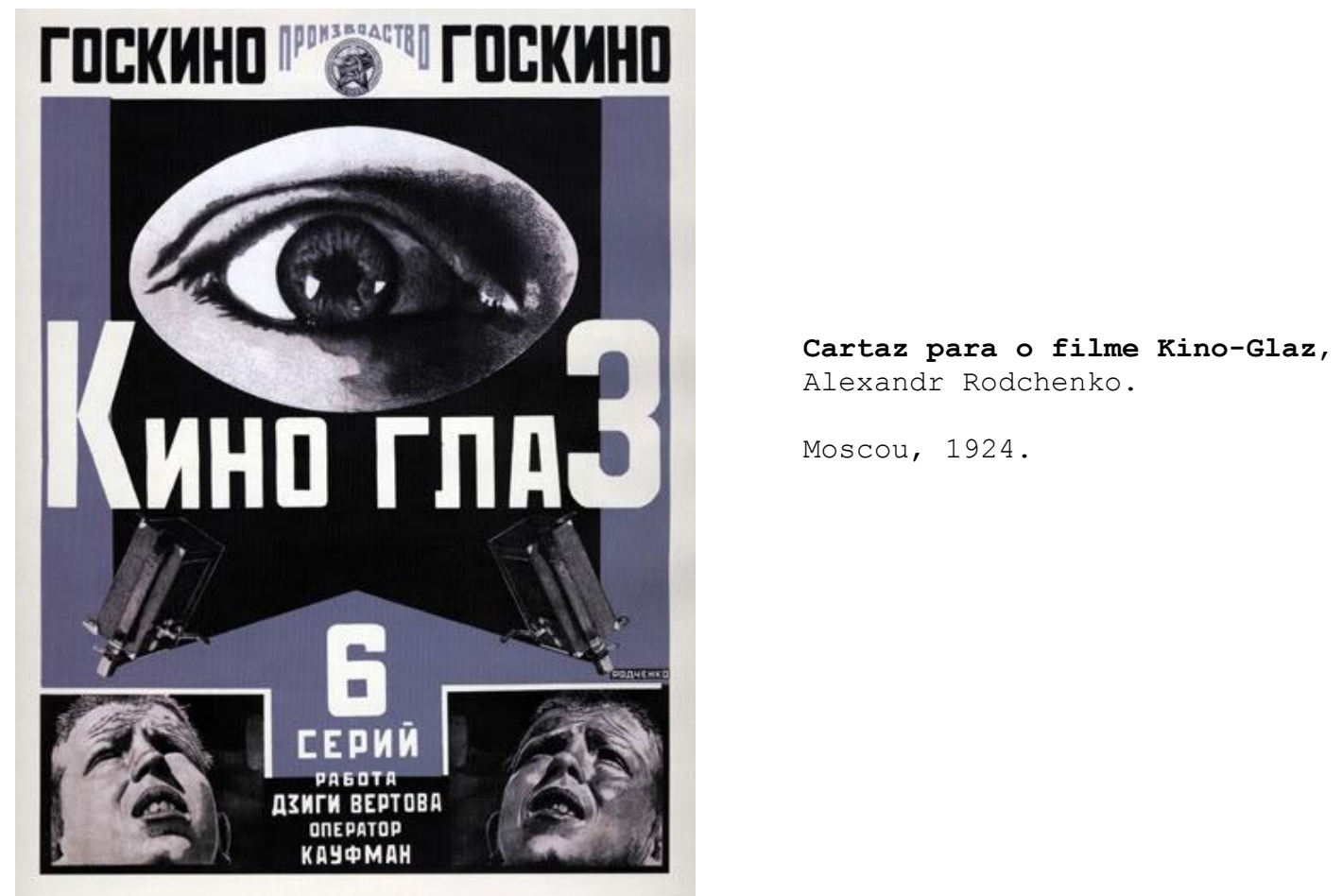

Nesse sentido, a kinematografiya de Vertov era radicalmente contrária ao cinema ficcional (ou "cinema encenado"). Ele considerava-o como uma "tentativa de despejar [o] modo revolucionário de vida em uma forma burguesa". ${ }^{97}$ Para o criador dos Kino-Pradas, toda forma de encenação presente nos filmes de Eisenstein era uma falsificação do conteúdo revolucionário apresentado nas tramas narrativas. A partir do momento em que a Revolução se instaurou no plano social, fazia-se necessário adaptar as formas cinematográficas à nova ordem social. As técnicas de construção cinematográfica dos "mestres do cinema" (referência aos cineastas do período anterior da revolução) não podiam se adequar ao contexto social da experiência cotidiana dos trabalhadores. E o cinema da Revolução, segundo

\footnotetext{
${ }^{97}$ VERTOV, Dziga, "The Factory of Facts and Other Writings", Kevin O'brian (trad.), in OCTOBER, Vol. 7, Cambridge, MIT Press, Winter 1978, p. 118.
} 
Vertov, deveria se fundar numa apresentação factográfica e clara dos temas e questões mais urgentes do cotidiano russo.

Há o filme-drama na tela. Os brancos e os vermelhos. Os brancos estão bebendo, dançando e beijando mulheres seminuas; durante os intelúdios, eles filmam prisioneiros vermelhos. Os [revolucionários] vermelhos na clandestinidade. Os vemelhos no fronte de batalha. Os vemelhos na luta. Os vermelhos conquistam a vitória e poem os broncos bêbados e suas mulheres na prisão. O conteúdo é bom, mas por que alguém deveria querer mostrar filmes de ficção baseados no mesmo velho clichê de cinco anos [atrás]?

$[\ldots]$

Após a Revolução de Outubro, o cinema foi confrontado com a difícil tarefa de adaptar-se à nova vida. Os atores que antes representavam serviçais civis do czarismo passaram a interpretar operários; aquelas atrizes que haviam representado damas da corte, agora interpretavam com trejeitos ao estilo soviete. Entretanto, ainda poucos (cineastas) perceberam que muitos desses trejeitos permaneceram, em muitos aspectos, emoldurados pela técnica burguesa e pela forma dramática (cênica). ${ }^{98}$

Nesse sentido, a forma-gênero cinematográfica tinha um papel decisivo para Vertov. Os temas e histórias concernentes à Revolução não podiam ser inseridos num tipo de cinematografia que outrora tinha servido como veículo da visão de mundo burguesa. ${ }^{99}$ Fazia-se necessário mostrar a vida cotidiana do trabalhador. Acostumá-lo a perceber sua experiência de vida como parte integrante da realidade que se configurava a partir da experiência política revolucionária. Permanecer na ficção seria dar um passo para trás. A luta proposta pelos textos nos quais Vertov apresentou a proposta do Kino-Glaz

\footnotetext{
${ }^{98}$ Idem, p. 115. (parênteses meus).

${ }^{99}$ De acordo com Vertov, todo o leque de recursos cinematográficos pertinente ao cinema do período czarista deveria ser descartado (técnicas de atuação teatral empregadas pelos atores do ramo, a decupagem como roteiro, etc.), tendo em vista que o contexto social revolucionário, para o documentarista, impelia o cinema a abandonar o trabalho com a ficção. Segundo a perspectiva do documentarista, em manifesto datado de 1926, "poucos cineastas viam claramente que o cinema não-teatral (com exceção dos noticiários e alguns filmes científicos) ainda não existia". Sobre este ponto ver Cinema-Eye: A Drawing in the Journal Lapot' in VERTOV, Dziga, "The Factory of Facts and Other Writings", Kevin O'brian (trad.), in OCTOBER, Vol. 7, Cambridge, MIT Press, Winter 1978, pp. 113-124.
} 
fora também uma luta contra "o narcótico elétrico das salas de projeção", ${ }^{100}$ e também contra a influência dos filmes "encenados", que desviavam a atenção dos trabalhadores dos problemas e das tarefas sociais no contexto russo.

Portanto, a prática do cinema construtivista se configurava, segundo perspectiva de Vertov, a partir de um procedimento que visava "capturar a vida - organizá-la - mostrá-la na tela”. ${ }^{101}$ Todo filme que, em sua concepção, fosse baseado em concepções estéticas predefinidas era considerado descartável do ponto de vista revolucionário (o "excentrismo" da FEKS, ${ }^{102}$ a "montagem de atrações", de Eisenstein, ${ }^{103}$ a montagem-manipulação, ${ }^{104}$ de Kuleshov, etc.). Para Vertov, os filmes que têm por objetivo "organizar a vida real" se

\footnotetext{
${ }^{100}$ Idem, p. 115.

${ }^{101}$ VERTOV, Dziga, "Dziga Vertov: The Cine-Pravda: A Report to the Cine-Eyes", in TAYLOR, Richard, Op. Cit., p. 113.

${ }^{102}$ A 'Fábrica do Ator Excêntrico' (FEKS) foi estabelecida em Petrogrado, em julho de 1922, após o sucesso da primeira manifestação teatral do grupo, Disput ob ekstsentricheskom teatre (Discupta sobre o Teatro Excêntrico), em dezembro de 1921. Em seu primeiro manifesto Ekstsentrism (Excentrismo), publicado em 1922 -, a FEKS atacava a tradição artística do passado, e sua substituição por novas formas culturais fundadas na ordem social do proletariado revolucionário. Tais formas, de acordo com o manifesto do grupo, deveriam ser extraídas do contexto cultural dos trabalhadores: principalmente o entretenimento: as feiras de variedades, o circo, o music-hall e também o cinema. Sobre este ponto ver TAYLOR, Richard, The politics of the Soviet cinema, 1917-1929, London, Taylor \& Francis, 1979, pp. 144-151. Ver também KOZINTSEV Grigori, TRAUBERG, Leonid, YUTKEVICH, Sergei e KRYZHISKY, Georgi, "Eccentrism", in TAYLOR, Richard, Op. Cit., pp. 58-64

${ }^{103}$ Segundo Vanessa de Oliveira, "a atração é a unidade de medida encontrada por Eisenstein para o cálculo da influência exercida pela arte sobre o espectador". Para a historiadora, Eisenstein desenvolveu um método de análise do espetáculo teatral (e também da recepção do espectador de cinema) de base científica, que visava direcionar a atenção do público, mediante o uso de recursos estilísticos capazes de exercer um choque emocional em sua atenção. Deste modo, Eisenstein procurou, por meio do trabalho com as emoções do espectador, desenvolver uma forma de arte utilitária (nos campos do teatro e do cinema), que visava transmitir idéias relacionadas ao contexto social e histórico da Revolução de Outubro. Ver OLIVEIRA, Vanessa, Eisenstein Ultrateatral, São Paulo, Perspectiva, 2009, pp. 117-130.

${ }^{104}$ De acordo com Robert Stam, "para a mentalidade prática de Kuleshov, [...] a arte cinematográfica consistia em exercer o controle sobre os processos cognitivos e visuais do espectador por meio da segmentação analítica de visões parciais. Em seu entendimento, o que distinguia o cinema de outras artes era a capacidade da montagem para organizar fragmentos dispersos em uma seqüência rítmica e com sentido". STAM, Robert, Film Theory: An Introduction, London, Wiley-Blackwell, 2002, p. 55. (Negritos meus). Sobre este ponto ver também KULESHOV, Kuleshov on Film: Writings by Lev Kuleshov, Ronald Evaco (Ed.), University of California Press, 1975.
} 
contrapõem àqueles fundados num tipo de agitação política fundado em sensações fortes (Eisenstein e FEKS, principalmente). ${ }^{105}$

\title{
IV: O cinema e a "Encomenda Social"
}

\begin{abstract}
O ano de 1924 é tardio se pensarmos em um bom número de artistas de vanguarda, cujas opções foram definidas entre 1912 e 1917 [...] e que foram reinvestidas do combate social, após a Revolução (1918-1920). Eisenstein chega "depois" da incrível aventura que conduziu - cada uma à sua maneira Vladmir Tatlin e Kasimir Malevitch ao extremo do formalismo, "ao último quadro" e à superação da arte. Ele também pouco conta com a admiração dos mais novos pelos mais velhos, jovens que, tais como Rodtchenko, Lissitzki ou os irmãos Stenberg, se julgam, às vezes, mais radicais que seus mestres. ${ }^{106}$
\end{abstract}

Foi também em 1924 que Eisenstein escreveu Montagem de Atrações no Cinema, ${ }^{107}$ texto no qual o diretor elucida aspectos de sua prática cinematográfica - técnica aplicada em $A$ Greve. Neste artigo, Eisenstein elabora uma argumentação sobre estratégias de construção fílmica, centradas no roteiro, no trabalho com os atores e na elaboração formal do plano fílmico, que tem como escopo político a utilização do cinema como ferramenta para exercer uma influência emocional sobre o espectador. É a partir dessa

\footnotetext{
${ }^{105}$ Segundo Vertov, "O filme-drama estimula os nervos. O Cine-Olho ajuda as pessoas a ver. O filme-drama encobre os olhos e o cérebro em uma névoa doentia. O Cine-Olho abre os olhos e clareia a visão". VERTOV, Dziga, "Fiction Film Drama and The Cine-Eye", in TAYLOR, Richard, Op. Cit., p. 116.

${ }_{106}$ ALBERA, François, Op. Cit., p. 159.

${ }^{107}$ EISENSTEIN, Sergei M., "The Montage of Film Attractions", in S. M. Eizenshtein Writings, 1922-34, TAYLOR, Richard (Ed. e trad.), London, BFI Publishing, 1987, pp. 39-58.
} 
premissa que Eisenstein se insere no contexto do debate construtivista sobre a relação entre o "encenado" e o "não encenado". Todavia, como bem observa Albera, é importante ressaltar que "a argumentação de Eisenstein [no contexto de tal debate] não recai sobre o caráter encenado ou não encenado do filme, mas sobre sua lógica construtiva". ${ }^{108}$ Para o cineasta, o material básico do cinema é a figura do espectador, que não é tomada como a de um consumidor, mas como parte integrante de uma coletividade, pertencente a uma classe social específica, determinado, portanto, por certa contingência social e histórica.

Nesse sentido, seus esforços em $A$ Greve foram dirigidos para a criação de um método eficaz de construção fílmica, que considerava a mente do espectador como um material a ser trabalhado. Para Eisenstein, o cinema não possui sentido, enquanto forma de arte revolucionária, se não servir efetivamente a um propósito de transformação da consciência do público. Tendo considerado essa "base material" - o espectador cinematográfico - e os meios pelos quais o cinema obtém efeitos emocionais, Eisenstein avalia, a partir de suas experiências teatrais com a "montagem de atrações" entre 19221924, que o objetivo do cinema tem por tarefa a transformação da consciência de classe.

Formulada inicialmente em Montagem de Atrações no Cinema e depois polemicamente defendida nos artigos Método de Realização de um Filme Operário ${ }^{109}$ e Sobre a Questão da Abordagem Materialista da Forma, ${ }^{110}$ tal

\footnotetext{
${ }^{108}$ ALBERA, François, Op. Cit., p. 218.

109 EISENSTEIN, Sergei M., "The Method of Making a Worker's Film", in S. M. Eizenshtein Writings, 1922-34, TAYLOR, Richard (Ed. e trad.), London, BFI Publishing, 1987, pp. 65-66.
} 
concepção de trabalho cinematográfico se relaciona tanto com o conceito de construção - formulada pelos primeiros artistas construtivistas - bem como com a noção produtivista da encomenda social. ${ }^{111}$ Segundo a perspectiva de Albera, "os dois primeiros filmes de Eisenstein, $A$ Greve e $O$ Encouraçado Potemkin, trazem as marcas das construções cênicas construtivistas e da organização plástica linear reivindicada por Rodchenko e seus amigos. Esses traços, entretanto, constituem os aspectos mais superficiais [da filiação do

${ }^{110}$ EISENSTEIN, Sergei M., "The Problem of the Materialist Approach to Form", in S. M. Eizenshtein Writings, 1922-34, TAYLOR, Richard (Ed. e trad.), London, BFI Publishing, 1987, pp. 59-64.

11 A noção de "encomenda social" pretendia se constituir numa reflexão do artista revolucionário sobre a tarefa da reconstrução do "modo de vida" e da percepção do proletariado. A encomenda, na acepção de Tret'iakov, podia ser compreendida, de modo geral, nos seguintes termos:

(I) Aspecto organizacional: o artista comprometido com a transformação social procura "cristalizar" o sentimento revolucionário na classe trabalhadora. Ele experimenta novas formas sensíveis capazes de transmitir, para as massas operárias, conceitos referentes ao processo revolucionário.

(II) Direcionamento de classe: A obra de arte, na perspectiva da encomenda, nunca possui uma universalidade, mas sempre é direcionada para uma classe específica. $O$ artista revolucionário deve compreender como sua obra atinge o público, e como participa da tarefa de educação das massas.

(III) Aspecto emocional: Tret'iakov enfatiza que o trabalho de conscientização das massas torna-se mais efetivo quando a obra de arte consegue provocar uma tensão emocional em seu público. Faz-se necessário, para tanto, que o artista possua um domínio preciso dos materiais com que trabalha.

(IV) Autonomia da arte: nenhum objeto artístico está fora da dinâmica do mercado, do consumo e das relações sociais. A autonomia da vontade criativa do artista é portanto, colocada em xeque, pois o conteúdo da obra de arte é determinado pela dinâmica da classe social à qual o autor pertence.

V) Arte e o fato histórico: os objetos, formas e temas da obra de arte comprometida com a revolução são escolhidos após uma pesquisa referente aos fatos e relações materiais que permeiam os processos sociais a serem abordados pelo artista. Para evitar uma possível falsificação da história no conteúdo da obra, o artista deve estudar os elementos históricos e materiais que permeiam a sua classe social, a fim de transmitir uma correta interpretação da história para seu público.

Tret'iakov, ao formular sua concepção de encomenda, rediscute a sociologia da arte do escritor Alexander Bogdanov (1873-1928), membro fundador da Proletkult, que considerava a atividade artística como instância capaz de sistematizar a realidade. $\mathrm{O}$ artista é visto, nessa perspectiva, como um psicoengenheiro social, que compreende a base material de seu trabalho artístico e o impacto emocional de sua obra no sujeito proletário, não permitindo que o estilo e as estratégias de composição de sua obra falsifiquem os fatos históricos aos quais ela se refere, ou menciona, e, por fim, direciona seu trabalho para uma tarefa específica na sociedade. Ver TRET'IAKOV, Sergei, "Art in the Revolution and the Revolution in Art (Aesthetic Consumption and Production)", in OCTOBER 118, Fall 2006, Cambridge, MA, MIT Press, pp. 11-18. Ver também TRET'IAKOV, Sergei, "Our Cinema", in OCTOBER 118, Fall 2006, Cambridge, MA, MIT Press, pp. 27-44. 
cineasta] à problemática construtivista". ${ }^{112}$ Em vista de tal fato, o historiador afirma que a concepção de montagem cinematográfica em Eisenstein "fundase, com efeito, em uma crítica aprofundada da teoria do ator de Meyerhold, da biomecânica e do deslocamento do centro de gravidade de seu trabalho em direção ao espectador, [que resultará] "tanto numa concepção da montagem (a montagem de atrações) [...] como numa compreensão da função social do filme. ${ }^{113}$

Tal compreensão da função social do cinema, desenvolvida por Eisenstein, se apóia no caráter decisivo dos efeitos emocionais, oriundos do uso da montagem. Para Eisenstein, trabalhar as emoções do espectador constitui uma tarefa acima de tudo política, na medida em que conseguiria transformar um mero espectador em agente do qual depende a constituição do significado da "justaposição" dos elementos fílmicos.

Igualmente, o "produto" artístico, para Tret'iakov, tinha como função afetar a capacidade intelectiva do público, assim como suas emoções. $\mathrm{Na}$ medida em que o trabalho artístico fosse ganhando mais precisão no trato de seus materiais, o caráter "intelectual" dos efeitos artísticos ganharia mais força. Segundo a perspectiva do crítico, o cinema soviético, a partir das experiências cinemáticas de Eisenstein com o filme, caminhava para uma forma na qual o conteúdo intelectual dos fatos apresentados na narrativa se fundiria, a partir da constituição formal do filme, aos elementos emocionais que seriam despertados no espectador. A montagem de atrações, ao justapor os diferentes

\footnotetext{
${ }^{112}$ Albera, Op. Cit., p. 233.

${ }^{113} / d e m$, pp. 233-234.
} 
"blocos" de construção cinematográfica, se constituiria como uma forma de agitação, que afetaria a capacidade intelectiva do espectador.

Para Tret'iakov, o cinema fundado na apresentação de fatos (filme documental, ou "não encenado"), deveria ser avaliado de maneira semelhante aos filmes de entretenimento e de agitação. Segundo a perspectiva do crítico, ambos os gêneros, deveriam ser avaliados segundo seu impacto social, independente de suas estratégias de construção formal. Contudo, os trabalhos voltados para o entretenimento requeriam uma atenção especial, pois tais filmes, ainda que empenhados na tarefa de agitação, poderiam distorcer o conteúdo revolucionário e/ou factual presente em suas narrativas. Nesse sentido, a crítica produtivista, para Tret'iakov, deveria empenhar-se em avaliar a função social dos gêneros cinematográficos, visando desta forma combater os elementos nocivos ao cinema soviético.

Todavia, cumpre ressaltar que o campo da análise cinematográfica era um objeto de estudo novo para os teóricos produtivistas. Segundo o historiador Ben Brewster, tratava-se de um campo de investigação teórica que ainda estava em processo de formação entre os anos de 1923 e $1928 .{ }^{114}$ As discussões dos teóricos produtivistas, a respeito da diferenciação entre os filmes "encenados" e "não encenados", partiam de análises focadas em diferentes objetos do âmbito fílmico. Tret'iakov construía sua análise a partir do "material" fílmico, independentemente do gênero, a fim de identificar as contribuições que cada um poderia oferecer ao campo artístico. Chklóvski dava especial ênfase à construção das narrativas dos filmes "encenados",

\footnotetext{
${ }^{114}$ BREWSTER, Ben, "Novy Lef with an Introduction", in Screen 12, Oxford University Press, 1971, pp. 59-102.
} 
valorizando seu potencial de agitação política. Brik, por sua vez, atribuía primazia ao conteúdo factual dos filmes não "encenados", apontando que o gênero encenado distorcia completamente o "material" histórico e factual presente nos fragmentos não decupados. Contudo, embora a argumentação dos teóricos produtivistas fosse fundada a partir de diferentes elementos da construção cinematográfica, pode-se afirmar que a questão sobre a função social do cinema (em ambos os "gêneros" - o encenado e o não encenado) constituía o denominador comum das posições dos autores. ${ }^{115}$

Segundo Tret'iakov, a distinção entre o "encenado" e o "não encenado" uma terminologia arbitrária em sua opinião - consistia no grau de "deformação" dos elementos que compõem o filme: a distorção arbitrária dos fragmentos fílmicos. Para o crítico, tal deformação se realizava em três instâncias:

(1) Na escolha do material.

(2) No processo de filmagem do material: a seleção dos ângulos de câmera, o arranjo da iluminação, etc.

(3) Na construção das seqüências do filmes, mediante o uso da montagem. ${ }^{116}$

Tendo em vista essas três instâncias, para Tret'iakov, os fragmentos fílmicos, os blocos de construção das seqüências, poderiam ser caracterizados como (1) flagrante, (2) roteirizado, e (3) encenado. Na medida em que os fragmentos fílmicos seriam organizados pelo cineasta, ele, inevitavelmente, introduziria sua perspectiva sobre o material "cru" (os fragmentos não decupados), inferindo-Ihe um significado. A tarefa do diretor de um filme "não

\footnotetext{
${ }^{115}$ Ver KURCHANOVA, Natasha, Against Utopia: Osip Brik and the Genesis of Productivism, PhD Thesis, New York, The City University of New York, 2005, pp. 272-275.

${ }^{116}$ Ver "Lef and Film: Notes of discussion (extracts) (New Lef No 11-12, 1927)", in BREWSTER, Ben, Op. Cit., pp 75-77.
} 
encenado" seria a de estabelecer uma finalidade clara, que fundamentasse a organização dos materiais filmados, procurando distorcer o mínimo possível o material factual presente nas filmagens. Neste sentido, a construção do filme de atualidades e do documentário, segundo a perspectiva da "encomenda social”, consistiria na organização correta dos elementos fílmicos. No caso dos filmes "encenados", a "encomenda social" seria a necessidade de fomentar a agitação política.

Para afetar o espectador, o cineasta empenhado em tal tarefa precisaria de liberdade que pudesse construir seqüências capazes de estimular emocionalmente seu público. Se um filme "encenado" não fosse capaz de afetar seu público de modo a impeli-lo à ação, ele não seria produtivo, do ponto de vista da encomenda social.

Para Tret'iakov, o fator fundamental para a realização cinematográfica não seria o de se ater aos componentes formais para a apresentação do material. Em lugar disso, a tarefa primeira do diretor de cinema consistiria na proposição de novas formas de percepção/recepção do material cinematográfico. As estratégias formais de construção fílmica somente adquiririam funcionalidade, se pensadas segundo tal objetivo. De acordo com Tret'iakov, "[...] ser um revolucionário não significa falar incessantemente sobre o presente, mas sim falar, infalivelmente, em conexão com o presente". ${ }^{117}$

Os diretores de cinema que ignorassem os elementos históricos e sociais mais urgentes, para se lançar "ao trabalho com temas clássicos, submetidos a reiteradas interpretações, [...] acabariam por realizar filmes com

\footnotetext{
117 TRET'IAKOV, Sergei, "Our Cinema", in OCTOBER 118, Fall 2006, Cambridge, MA, MIT Press, p. 33.
} 
materiais [...] já despersonalizados" (ou desatualizados). ${ }^{118}$ No contexto do Estado soviético, faz-se necessário transformar, dizia Tret'iakov, a "cinecrônica" [o cinema "encenado", ou o cinema centrado na construção de uma narrativa] "em uma grande janela através da qual o espectador poderá usar seus olhos para compreender e analisar"119 os processos sociais e os conflitos presentes no Estado soviético, e impeli-lo a participar de sua construção. 


\section{TERCEIRO CAPÍ'IULO: \\ O espectador como material cinematográfico}

\section{I: Eisenstein: do Exército Vermelho à Cultura Proletária}

As várias biografias de Eisenstein ${ }^{120}$, assim como seus relatos autobiográficos $^{121}$, nos indicam que seu interesse pelas questões políticas e pela revolução bolchevique se deu algum tempo após deixar o Instituto de Engenharia Civil, em Petrogrado Em 1918, ele se alista no Exército Vermelho, atendendo à convocação para o serviço militar obrigatório e é enviado à Escola Oficial de Engenharia, na cidade de Izhora, para auxiliar na construção de estruturas de engenharia militar. Sua habilidade com o desenho o leva, em julho de 1920, a ser destacado para trabalhar na decoração dos trens do exército que se deslocavam para as linhas de batalha. Nessa função, ele elabora slogans, caricaturas das forças contra-revolucionárias (figura políticas importantes do menchevismo) e do antigo regime czarista, além de cenários para as pequenas trupes teatrais que atuavam nos clubes culturais improvisados, na linha de frente ocidental do Exército Vermelho.

O teatro que se desenvolveu nas frentes de batalha tinha como principal intuito elaborar espetáculos (dramas, comédias, esquetes sobre higiene e saúde, etc.) que pudessem fornecer entretenimento e conscientização política.

\footnotetext{
${ }^{120}$ BULGAKOWA, Oksana, Sergei Eisenstein: A Biography, San Francisco, Potemkinpress, 2002. SETON, Marie, Sergei M. Eisenstein: A Biography, New York, A.A. Wyn, 1952.

${ }^{121}$ EISENSTEIN, Sergei, Memórias Imorais: Uma Autobiografia, São Paulo, Cia das Letras, 1987.
} 
Designado teatro de agitação (agitkı), as encenações procuravam mobilizar o ânimo das tropas "em torno dos objetivos imediatos da Revolução (conquista definitiva dos territórios ocupados pelos contra-revolucionários, combate emergencial às conseqüências da guerra civil, como a carência de alimentos, e divulgação dos acontecimentos)". ${ }^{122}$ A experiência como decorador de trens e cenógrafo/figurinista dos agitki permitiu que Eisenstein se dedicasse integralmente à atividade artística e à pesquisa de diversos temas e autores no âmbito da teoria do teatro clássico e moderno (Molière (1622-1673), Ibsen (1828-1906), Shakespeare (1564-1616)), além de manifestos de Vsevolod Meyerhold (1874-1940) e Georg Fuchs (1881-1944). Para a historiadora do teatro Vanessa de Oliveira, "Eisenstein, nesse momento de consolidação da Revolução Bolchevique (segunda metade do ano de 1920, quando as derrotas do Exercito Branco, Menchevique, apontavam para o fim da guerra civil), ${ }^{123}$ estava concentrado em abarcar um vasto conhecimento teatral num pequeno espaço de tempo, em elaborar imagens de espetáculos ligados à tradição teatral, ao teatro moderno e ao teatro popular do Ocidente e da Europa Oriental, e motivado a pensar um novo teatro, sintonizado com os novos tempos”. ${ }^{124}$ É possível dizer que a vivência revolucionária do cineasta, durante seus anos de serviço militar - anos nos quais ele se politizou -, não pode ser dissociada de seu primeiro contato com a prática e a teoria teatral

Entre os anos de 1921 e 1922, Eisenstein se inscreve nos cursos ministrados por Meyerhold (naquele momento, um dos maiores expoentes do teatro soviético, atuando também como diretor do Departamento Teatral do

122 GARCIA, Silvana, "Teatro da Militância", p. 12, apud OLIVEIRA, Vanessa, Eisenstein Ultrateatral, São Paulo, Perspectiva, 2009, p. 3.

${ }_{123}$ HOBSBAWM, Eric, Historia Del Siglo XX, Madri, Critica, 2007, p. 71.

${ }^{124}$ OLIVEIRA, Vanessa, Op. Cit., p. 4. (parênteses meus) 
NARKOMPROS, em Moscou), na seção moscovita dos Laboratórios Estaduais Superiores de Encenação (GVYRM, posteriormente, em 1922, Laboratórios Estaduais Superiores de Teatro - GVYTM). Nesses cursos, o cineasta estuda direção e a teoria da biomecânica, disciplina criada a partir dos próprios experimentos de Meyerhold com a linguagem teatral. $\mathrm{O}$ aluno, durante seu período de formação nos laboratórios, assimila do professor a inclinação para a precisão (quase científica) com o trato dos elementos cênicos e da atuação. Entretanto, com o passar o tempo, Eisenstein acaba por considerar que "a preocupação de Meyerhold com uma 'ciência artística' não passava de empiricismo puro, não se refletindo numa prática e numa metodologia. [...] Foi no terreno da biomecânica e da análise da expressividade do ator que se deu a maior batalha entre os dois artistas". ${ }^{125}$ Grosso modo, a biomecânica de Meyerhold pode ser definida como um sistema de treinamento físico constituído de exercícios cênicos, retirados de movimentos coordenados, baseados na acrobacia circense, no boxe, na dança, etc., que tinha por objetivo ampliar a expressividade do ator. Para o diretor, a disciplina física proporcionava uma gama maior de movimentos plásticos que, durante o curso da atuação, maximizariam o potencial expressivo da ação cênica. Nesta perspectiva, a corporalidade do ator era o princípio fundamental da linguagem teatral. Para dominar a linguagem teatral se fazia necessário, considerava Meyerhold, aprimorar a capacidade motora da "máquina corporal" que movia a encenação ${ }^{126}$.

\footnotetext{
${ }^{125}$ Idem, p. 7.

${ }^{126}$ Para mais informações sobre a teoria da biomecânica de Meyerhold, ver LAW, A. e GORDON, Mel, Meyerhold, Eisenstein and Biomechanics, Jefferson, McFarland, 1996, pp. 3447.
} 


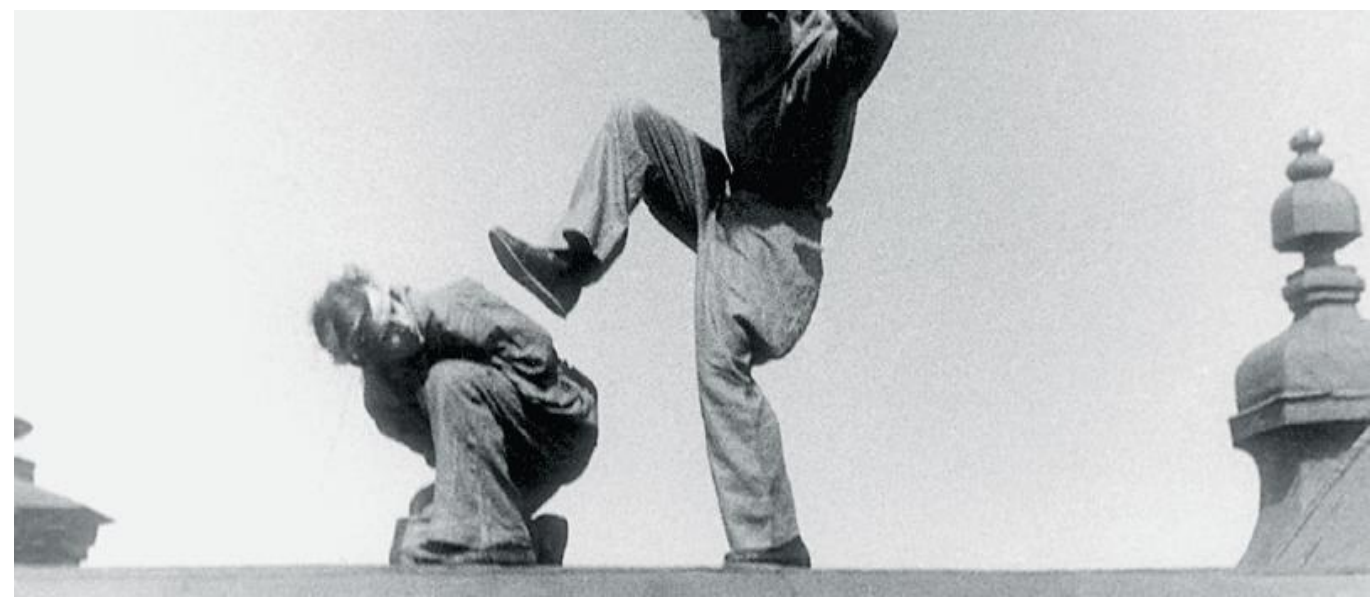

Vsevolod Meyerhold, Biomechanical Exercise "Le Gifle", sobre los tejados de Moscou, 1934, Black and white photograph, Colección B. Picon-Vallin, Photograph Archives B. Picon-Vallin, (C) Vsevolod Meyerhold, 2007.

Eisenstein, em 1923, incentivado pelo seu professor a desenvolver uma fundamentação teórica para a prática com a biomecânica, escreve junto com Tret'iakov o artigo Movimento Expressivo ${ }^{127}$. Todavia, este artigo, ao invés de dissertar sobre as técnicas de trabalho corporal desenvolvidas pelo professor, apresenta uma interpretação própria dos autores sobre o treinamento físico para o ator, tendo como base o livro Ginástica Expressiva (Ausdruckgymnastik) de Rudolf Bode (1881-1971). Para Eisenstein e Tret'iakov, o movimento expressivo, em resumo, é o movimento corporal orientado para a prática artística (teatral), produto do conflito entre os reflexos condicionados movimentos involuntários que o corpo executa durante seu dia a dia - e os movimentos conscientes $-\mathrm{a}$ vontade consciente do ator. ${ }^{128} \mathrm{~A}$ diferença entre estes dois tipos de movimentos reside, para Eisenstein e Tret'iakov, na necessidade do movimento consciente - uma vez orientado para a atividade teatral - ter um fim específico: afetar emocionalmente o espectador. De acordo

\footnotetext{
${ }^{127}$ EISENSTEIN, Sergei, TRETYAKOV, Sergei, "Expressive Movement," (trans.) Alma H. Law, in Millenium Film Journal, n. 3, Spring-Winter 1979, pp. 30-38.

${ }^{128}$ Idem, p. 35-36.
} 
com Oliveira, Movimento Expressivo já antecipa alguns elementos da Montagem de Atrações $^{129}$ (artigo publicado também em 1923, no terceiro volume da Revista $L E F$, na medida em que coloca o fator emocional do espectador como ponto principal da argumentação. De acordo com a perspectiva apresentada no texto, é o movimento intencional do ator que procura afetar os movimentos involuntários da platéia, por meio da ação cênica. O destaque não está mais na capacidade física do ator em estimular a platéia (tal como propõe a biomecânica de Meyerhold), ${ }^{130}$ mas na relação que este movimento estabelece com o público, quais são os meios mais efetivos para afetá-lo, e como a relação ator-platéia pode moldar (mediante a violência de um choque emocional) a percepção sensível do espectador, a fim de construir uma forma apropriada de teatro para a tarefa de conscientização política.

Antes mesmo de ingressar nos laboratórios de Meyerhold, a experiência teatral de Eisenstein no exército Ihe valeu prestígio suficiente para trabalhar profissionalmente em Moscou. No final do ano de 1920, após deixar o Exército Vermelho, Eisenstein é convidado a ocupar a função de cenógrafo-chefe no Peretru (Primeiro Teatro Operário da Proletkult). Os trabalhos que o cineasta desenvolveu dentro da Proletarskaia Kultura (Cultura Proletária) foram de vital importância para o desenvolvimento artístico de sua obra posterior no cinema,

\footnotetext{
${ }^{129}$ EISENSTEIN, Sergei, "Montagem de Atrações", in XAVIER, Ismail (org.), A Experiência do Cinema, São Paulo, Ed. Perspectiva, 1989, pp. 187-198.

${ }^{130}$ De acordo com a perspectiva de Tret'iakov, a técnicas de expressão corporal desenvolvidas pela teoria da biomecânica de Meyerhold, por si só, garantiam a construção de peças capazes de serem consideradas "utilitárias". O dramaturgo considera que a biomecânica é uma importante ferramenta de trabalho corporal do ator, e que ela contribui bastante para criar uma dinâmica emocional com o espectador. Entretanto, essa ferramenta deve ser adaptada para o desenvolvimento de um teatro ligado às tarefas sociais revolucionárias: politização, educação, etc. TRET'IAKOV, Sergei, "The Theater of Attractions", in OCTOBER 118, Fall 2006, Cambridge, MA, MIT Press, PP. 19-26.
} 
e em sua inserção no debate artístico instaurado nos primeiros anos da década de 1920.

A Proletkult, até o ano de 1922, foi uma organização cultural que gozava de completa autonomia em relação ao Estado soviético, apesar do financiamento estatal (via o NARKOMPROS) que recebia para tocar suas atividades. Criada em 1917, sob a liderança do Alexander Bogdanov (18731928) e Anatólií Lunachárskií (1875-1933), ela tinha como objetivo difundir atividades culturais entre os trabalhadores e, principalmente, a experimentação artística, visando à formulação de uma "cultura proletária", dissociada dos valores da cultura burguesa. De acordo com seus líderes, a arte não devia se restringir somente à tarefa da representação do ponto de vista de uma determinada classe social, ela deveria tornar-se uma prática útil que pudesse colaborar para a organização política dos trabalhadores. ${ }^{131}$

Os princípios que norteavam os trabalhos do movimento foram fortemente influenciados pelo trabalho teórico de Bogdanov, que pregava a indissociabilidade entre as esferas cultural, econômica e política no âmbito da revolução. De acordo com sua perspectiva, a filosofia de Marx não fornecia elementos suficientes para a formulação de uma revolução cultural proletária. ${ }^{132} \mathrm{O}$ proletariado devia ser encorajado a desenvolver suas próprias formas culturais, a partir de seus valores de classe - camaradagem,

\footnotetext{
131 "K sozyvu Vserossiiskoi kul'turno-prosvetitel'noi konferentsii rabochikh organizatsii," Proletarskaia kul'tura, no. 1 (1918), p. 27, Apud MALLY, Lynn, Culture of the Future: The Proletkult Movement in Revolutionary Russia, Berkeley, University of California Press, 1990, p. 43.

${ }_{132}$ BOGDANOV, Alexander, Ted Crowford (trad.), Adam Buick (trad.), "The Workers' Artistic Inheritance", in The Labour Monthly, September 1924, Bogdanov, pp. 549-597. Sobre esse ponto ver também A. Bogdanov, "Rezoliutsii konferentsii" Proletarska kul'tura, 5 (1918), p. 32, apud MACKENZIE, Melody, Tektology: Russian Constructivism and Man with a Movie Camera, University of Victoria, Canada, Master Degree Thesis, 2008, p. 12.
} 
cooperativismo e colaboração -, a fim de concretizar a construção da sociedade socialista. ${ }^{133}$ No campo teórico, o objetivo principal de Bogdanov era estabelecer um sistema conceitual que aproximasse o trabalho físico do intelectual, diminuindo a distância entre os "trabalhadores organizadores" e os "trabalhadores executores".

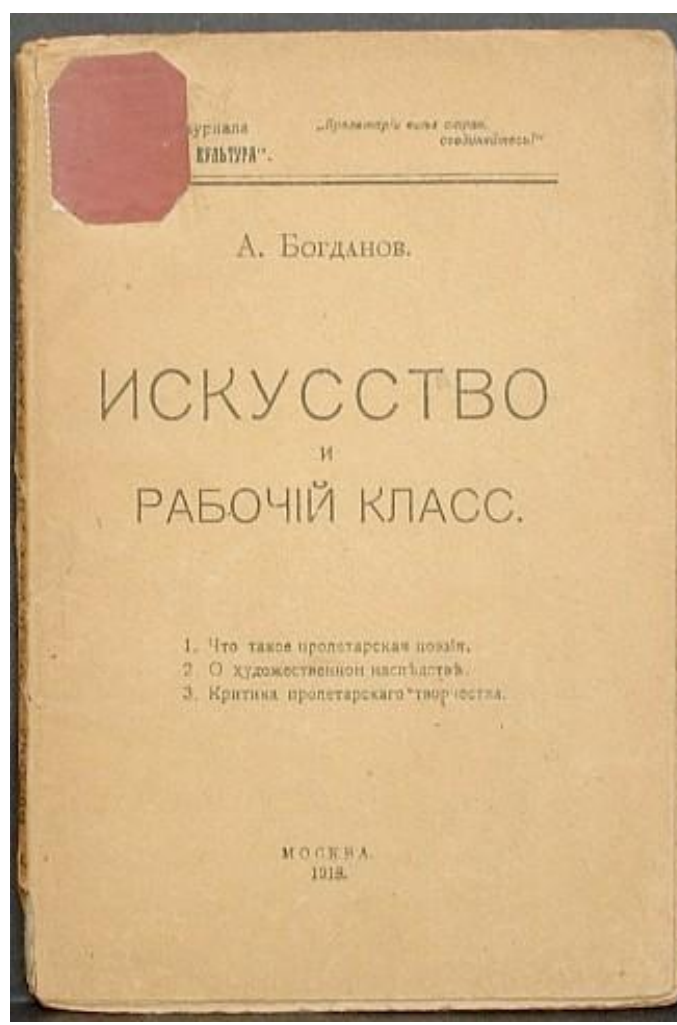

\author{
Alexander Bogdanov \\ ISKUSSTVO I RABOCHY \\ KLASS (Art and Working \\ Class) \\ Moscow: "Proletarian \\ Culture", 1918.
}

\footnotetext{
${ }^{133}$ Bogdanov, durante os primeiros anos após a Revolução de 1917 trabalhou arduamente no desenvolvimento de um sistema filosófico, a partir das teorias de Marx, que pudesse oferecer novas formas de organização social do trabalho para o proletariado revolucionário. Desse estudo, nasceu a disciplina da Tektologia. Sobre este ponto ver GORELIK, George, "Bogdanov's Tektology: Its Nature, Development and Influence", in Studies in Soviet Thought, Vol. 26, No. 1 (Jul., 1983), pp. 39-57. Ver também BOGDANOV, A., El arte y la cultura proletaria, Madrid, A. Corazón, 1979, trad. Ema Rosa Fondevilla.
} 
De acordo com essa perspectiva teórica, a educação artística tinha um papel prático decisivo na tarefa da construção de novas formas de organização produtiva e social para a classe proletária. Para Bogdanov, seria necessário ao proletariado o conhecimento de outras formas organizacionais, extraídas de elementos da experiência artística do passado. ${ }^{134}$ Tratava-se de uma proposta que visava estimular o trabalhador mais simples a desenvolver práticas sociais coletivas, por meio de uma educação artística que privilegiasse a crítica do individualismo da arte tradicional. ${ }^{135}$ Bogdanov considerava que a classe proletária deveria se tornar consciente do significado histórico das formas de "organização de vida e de pensamento" ${ }^{136}$ presentes na arte do passado, e compreender em que medida essa arte se relacionava (ou não) com sua experiência social.

A postura de Bogdanov sobre a apropriação crítica da "arte do passado" era largamente aceita pelas lideranças do movimento e foi incorporada aos preceitos básicos que norteavam a atuação da Proletarskaia Kultura. No entanto, na visão do movimento, o aprendizado crítico do proletariado conduziria a um rompimento total com os princípios estéticos que norteavam

\footnotetext{
${ }^{134}$ Com base no material bibliográfico coletado durante o trabalho de pesquisa para esta dissertação, pode-se dizer que Bogdanov, ao discutir o papel da arte na educação cultural da classe proletária, não se refere diretamente a movimentos artísticos específicos (realismo, simbolismo, etc.). Em suas discussões sobre o tema, o teórico ataca, grosso modo, as formas culturais das classes dominantes (burguesia, aristocracia, etc.). Dos textos disponíveis analisados, A Herança Artística dos Trabalhadores é o trabalho no qual Bogdanov discorre mais longamente sobre questões estéticas e sua relação com a cultura proletária. Ver BOGDANOV, Alexandr, "The Workers' Artistic Inheritance", Ted Crawford \& Adan Buick (trad.) in The Labour Monthly, London, The Labour Publishing Company Ltd., September 1924, pp. 549-597

135 "O artista, por sua posição social, é um intelectual, ele está acostumado a trabalhar individualmente, sem perceber em que medida o seu trabalho está conectado com o trabalho coletivo da humanidade [...]. Neste contexto, a posição dos intelectuais esforçados é muito pouco diferente da burguesia [...]". Idem, p. 560.

${ }^{136}$ Idem, Loc. Cit.
} 
essa "arte do passado" (simbolismo, expressionismo, realismo, etc.). ${ }^{137}$ Se revolução de outubro de 1917 fora uma ruptura radical com as estruturas políticas criadas pelo regime czarista e o governo provisório organizado pelo menchevismo, as formas culturais e artísticas criadas a partir da experiência organizacional do proletariado também deveriam estabelecer uma ruptura com as formas artísticas que legitimavam o status quo político do passado czarista. Trata-se de uma proposta de arte, baseada na organização social coletiva do proletariado - organização que, no campo político, levara aos movimentos grevistas e à luta política revolucionária entre 1905 e 1917.

Se o coletivismo constituíra um valor fundamental para a vida cotidiana proletária e também para sua ação política desde 1905, logo, também deveria sê-lo para a arte que a Proletarskaia Kultura construiria. Trata-se de um ponto chave para compreender a dinâmica ideológica que norteava o grupo, uma vez que, para Bogdanov, o coletivismo deveria aparecer na produção e no conteúdo da nova obra de arte e ser a ela intrínseco. ${ }^{138}$ De acordo com tal perspectiva, a arte deveria representar e retratar a vida cotidiana de maneira clara e sintética, de modo a ser facilmente compreensível para o trabalhador mais simples. Não se tratava apenas de estabelecer uma dinâmica de trabalho

\footnotetext{
${ }^{137}$ De acordo com os dados historiográficos coletados pela historiadora Lynn Mally, em Culture of the Future: The Proletkult Movement in Revolutionary Russia, uma parte dos proletários que militavam no movimento da Proletkult (principalmente nas regiões periféricas, afastadas de Moscou) estava insatisfeita com as propostas das lideranças principais do movimento (em sua maioria, membros do movimento que não tinham origem proletária). Este fato proporcionou 0 surgimento de lideranças locais, chefiadas por membros proletários que, apesar de não disporem de educação superior, logravam organizar atividades culturais. Como exemplo, Mally cita o caso do torneiro mecânico Andrei Kozochkin que, por volta do ano de 1920, foi eleito presidente da Proletkult de Izhevsk (cidade localizada a mil quilômetros a leste de Moscou), após ter conseguido administrar com sucesso o teatro dos operários da indústria metalúrgica da região. Ver "Doklad o deiatel'nosti Izhevskogo Proletkul'ta," TsGALI f. 1230, op. 1, d. 1221, I. 1. Apud MALLY, Lynn, Op. Cit., p. 104-105.

${ }^{138}$ Sobre este ponto ver BOGDANOV, Aleksandr, "The Proletarian and Art (1918)", in BOWLT, John E. (org.), Russian art of the Avant-Garde Theory and Criticism 1902-1934, London, Thames and Hudson, 1988, p. 176.
} 
com as formas e conteúdos artísticos que potencializassem o caráter educacional do trabalho final, mas de desenvolver um regime de atividade prática que contribuísse para disseminar o espírito coletivo - cultivar a "consciência coletiva" - nos trabalhadores que elaboravam as atividades ("trabalhadores organizadores") e nos trabalhadores que participavam dessas atividades ("trabalhadores executores").

Em síntese, o objetivo da Proletkult era incorporar aspectos mais avançados da arte burguesa e negar sua inspiração individualista (grosso modo, a idéia do gênio criativo individual) para construir uma arte pautada no esforço de organização coletiva do proletariado. Todavia, no âmbito prático, a espontaneidade do trabalho da Proletarskaia Kultura acabou gerando problemas. A quantidade extremamente grande de atividades realizadas, que visavam abarcar a totalidade do número de filiados, que aumentava constantemente (o número massivo de filiados chegou aproximadamente à casa de meio milhão, em 1920), ${ }^{139}$ fugia ao controle da organização. Segundo a historiadora Lynn Mally, "o ecletismo do movimento perturbava muitos participantes, já que era precisamente essa diversidade que contribuiu para sua notável popularidade. A Proletkult foi simultaneamente vanguardista e popular, agitacional e educacional, uma continuação das tendências prérevolucionárias (os coletivos culturais e clubes de recreação que se desenvolveram nas fábricas russas durante o movimento grevista de 1905 até 1917) e uma tentativa de fazer algo completamente novo. Seus programas ofereciam recitais de poesia para estenógrafos, lições de pianos para pintores

${ }^{139}$ MALLY, Lynn, Op. Cit., p. 68. 
de casa e a chance de maquinistas se tornarem atores profissionais". ${ }^{140} \mathrm{~A}$ espontaneidade e o amadorismo de muitas manifestações internas levaram as lideranças do movimento a concluir que a primeira tarefa da organização deveria ser o treinamento de uma vanguarda proletária que pudesse inspirar o desenvolvimento cultural dos membros que careciam de educação cultural sólida. "Em outras palavras, a cultura proletária deveria inicialmente ser fomentada por uma elite proletária". 141

\title{
II: A montagem de atrações
}

\begin{abstract}
Em duas palavras: o programa teatral do Proletkult não consiste na "utilização dos valores do passado", nem na "invenção de novas formas de teatro", mas na abolição da própria instituição do teatro enquanto tal, substituindo-a por um local de apresentação de experiências que visam elevar o nível organizacional cotidiana das massas. A organização de oficinas de trabalho e a elaboração de um sistema científico para a elevação deste nível são tarefas imediatas da seção científica do Proletkult no campo teatral. ${ }^{142}$
\end{abstract}

O manifesto Монтаж аттракционов (Montagem de Atrações) ${ }^{143}$ marcou a entrada de Eisenstein revista da Frente Esquerda das Artes - LEF, no ano de 1923. Este texto ofereceu ao leitor da época uma síntese dos experimentos teatrais realizados pelo diretor no âmbito da Proletarskaia Kultura, a partir do processo de construção de Na vsjakogo mudreca dovol'no prostoty (Todo sábio tem um pouco de estupidez) - texto original de Alexandr Ostrovsky (1823-

\footnotetext{
${ }^{140}$ Idem, pp. 213-214, (parênteses meus).

141 MACKENZIE, Melody, Op. Cit., p. 15.

${ }^{142}$ EISENSTEIN, Sergei, "Montagem de atrações", in XAVIER, Ismail (Org.) A Experiência do Cinema, São Paulo, Ed. Perspectiva, 1988, p. 187.

${ }^{143}$ Idem, pp. 187-198.
} 
1886), adaptado por Sergei Tret'iakov. Montagem de atrações foi também o trabalho que assinalou as principais influências teóricas que norteariam prática artística de Eisenstein durante o restante da década de 1920, e marcou a entrada do diretor no debate construtivista sobre a arte utilitária.

Durante os primeiros anos da década de 1920, o teatro soviético procurou inspiração nas artes populares, tais como o circo e o music-hall. Os diretores mais inovadores do teatro russo se esforçaram por romper completamente com as tradições do drama burguês - tramas psicológicas e temas domésticos - a fim de criar formas de encenação adequadas para disseminar o debate político entre os trabalhadores mais simples. ${ }^{144}$ No âmbito do teatro, o espírito de colaboração entre diferentes tipos de artistas estava largamente disseminado, o que levou aos mais inusitados experimentos. Em 1919, o pintor e diretor Yuri Annenkov (1889-1974), em sua versão para $O$ Primeiro Destilador de Tolstoi, introduziu palhaços em diversos atos, modificando o cenário do inferno em um circo e os demônios em acrobatas. $O$ Campeão da Luta de Classes Universal, espetáculo de agitação e propaganda política criado pelo palhaço Vitaly Lazarenko (1890 - 1939), em cartaz durante 1920-22, contou com a participação de Maiakovskii no trabalho de encenação. ${ }^{145} \mathrm{Na}$ Fábrica do Ator Excêntrico (FEKS), peças originais e adaptações de clássicos russos foram construídas a partir da mistura de elementos oriundos dos números de cabaré e também do cinema. ${ }^{146}$

\footnotetext{
${ }^{144}$ GEROULD, Daniel, "Eisenstein's 'Wiseman'", in The Drama Review: TDR, Vol. 18, No. 1, Cambridge, MA, The MIT Press, 1974, pp. 71-76.

${ }^{145}$ MAYAKOVSKY, Vladmir, František Deak (Trad.), "The Championship of the Universal Class Struggle", in The Drama Review: TDR, Vol. 17, No. 1, MIT Press, 1973, pp. 53-63.

${ }_{146}$ DEÁK, František, "Two Manifestos: The Influence of Italian Futurism in Russia", in The Drama Review: TDR, Vol. 19, No. 4, MIT Press, 1975, pp. 88-94.
} 
Em meio a toda essa efervescência no ambiente teatral russo, Eisenstein estreou como decorador-chefe do Teatro da Proletkult. Seu primeiro trabalho importante foi $O$ Mexicano de Jack London (1876-1916), texto adaptado por Boris Arvatov. Nessa peça, ele adicionou traços característicos da pintura cubo-futurista à encenação e aos figurinos, introduzindo formas geométricas variadas no primeiro e no segundo ato. Contudo, a grande contribuição do cineasta à peça foi a inserção de uma luta real de boxe no meio da platéia. Devido à questões técnicas, o ringue foi montado no proscênio, ${ }^{147}$ permitindo que os espectadores pudessem acompanhar bem de perto a ação dos atores que pelejariam. Tratava-se de um artifício que estabeleceu, naquele momento específico da encenação, um rompimento "com a separação cenapúblico. Pseudo-espectadores semeavam a confusão entre os espectadores, e no fim (da luta de boxe) salvas de fogos estouravam debaixo das poltronas, acompanhadas de ações burlescas e de uma cacofonia musical que contrastava com o realismo da luta em que o herói revolucionário devia triunfar". ${ }^{148}$ A cena proposta por Eisenstein pretendeu atacar o caráter passivo da platéia, visando fazer o espectador vivenciar as emoções de uma ação física relacionada à atividade revolucionária (o protagonista da peça participa da luta de boxe, visando um prêmio em dinheiro, para contribuir com a causa de um grupo revolucionário).

O procedimento adotado no grand finale de $O$ Mexicano se tornou praticamente regra em $\mathrm{Na}$ vsjakogo mudreca dovol'no prostoty, primeiro espetáculo dirigido e montado por Eisenstein, em 1923. Em Mudrec, Eisenstein

\footnotetext{
${ }^{147}$ Parte anterior dos palcos de teatro, junto à ribalta (parte dianteira do palco), que se estende para fora do pano de boca, onde ficam os refletores.

${ }^{148}$ ALBERA, François, Op. Cit., p. 235. (parênteses meus).
} 
pôde trabalhar os elementos cênicos com muito mais liberdade, adaptando-os aos princípios da montagem de atrações. De acordo com o diretor, o cenário reduzido ao essencial, servia como instrumento para potencializar o desempenho do ator (mediante a criação de um espaço que se relacionasse esteticamente com os movimentos corporais que desempenharia durante a atuação) e fora construído com pedaços de maquinaria (cabos e chapas de metal)". ${ }^{149} \mathrm{O}$ espaço físico do teatro que comportou o espetáculo (um antigo teatro privado, que ficava em uma mansão no centro do Moscou) ${ }^{150}$ foi transformado num picadeiro circense:

"[...] Os espectadores [ficavam] sentados em duas arquibancadas. Estas eram separadas por uma passagem de acesso e cercavam a metade da pista circular coberta por um tapete verde. As paredes da sala que delimitavam o espaço da apresentação foram cobertas por um tecido escuro, deixando aparecer na porção superior das paredes a decoração pomposa de um antigo teatro. Um tecido listrado, por sua vez, se antepunha ao tecido escuro cobrindo também a porção inferior das paredes da sala. Em meio à arena [similar a de um circo], uma plataforma de dois níveis era empregada para todas as seqüências, por meio de algumas adaptações. ${ }^{151}$

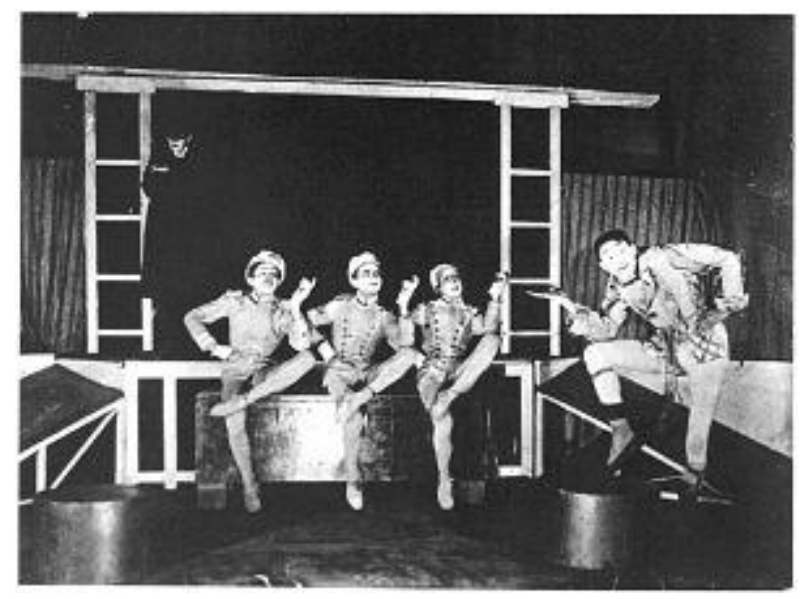

Parte central do palco de $N a$ vsjakogo mudreca dovol'no prostoty.

149 TAYLOR, Richard (Org), S. M. Eisenstein: Selected Works, Writings, 1934-1947, London, British Film Institute, 1996, p. 4. (parênteses meus).

${ }_{150}$ GEROULD, Daniel, Op. Cit., p. 77

151 Oliveira, Vanessa, Op. Cit., p. 54. 
A dramaturgia que Tret'iakov desenvolveu para a peça, por sua vez, transportou os personagens de Ostrovsky (1823-1886) para o século XX, transformando originalmente um melodrama de ascensão social e intriga familiar em uma sátira de cunho social e político. As personagens foram reescritas de forma a personificarem caricaturas de figuras políticas, que podiam ser facilmente reconhecidas pela platéia (políticos famosos, personalidades que apareciam constantemente em jornais, etc.). Visando inflamar os ânimos da platéia, o dramaturgo "afiou" a sátira social presente no texto original, por meio da adição de ofensas burlescas às instituições religiosas e capitalistas da Rússia pré-revolucionária.

Apesar do forte apelo político do texto adaptado pelo trabalho dramatúrgico de Tret'iakov, o método de construção da montagem de atrações de Eisenstein não privilegiou nenhum elemento específico da encenação teatral como fator preponderante. Segundo o diretor esta forma de construção do espetáculo teatral consistia em dois princípios básicos: "[1] O próprio espectador passa a constituir o material básico do teatro; [2] o teatro utilitário [...] sempre tem por meta orientar o espectador numa determinada direção (estado de espírito)". ${ }^{152}$ Uma vez colocada a figura do espectador como elemento fundamental do espetáculo, Eisenstein utilizou todos os componentes da máquina teatral (texto, cenografia, iluminação, figurino, etc.) em Mudrec para estimular e afetar os nervos da platéia, a fim de transmitir agressivamente o conteúdo político do texto adaptado da peça.

A atração é a unidade estrutural que Eisenstein utilizou para construir sua prática teatral na Proletkult. Os aspectos cênicos outrora considerados

${ }^{152}$ EISENSTEIN, Sergei, Montagem de Atrações, p. 189. 
como ornamento pelo teatro baseado no drama burguês do século $X I X,{ }^{153}$ não são mais elementos acessórios para o diretor. São justamente esses elementos de forte apelo visual, retirados das formas de espetáculo populares (teatro de variedades, números circenses, etc.), que entram destacados nas cenas. Em Montagem de Atrações, não há hierarquia entre os blocos de construção que compõem a encenação teatral: "a atração [...] é todo aspecto agressivo do teatro, ou seja, todo elemento que submete o espectador a uma ação sensorial ou psicológica". ${ }^{154}$ Para Eisenstein, as diferentes partes constituintes do espetáculo - fala, gesto, cor, luz, etc. - devem ser montadas em função da necessidade do espectador "perceber o aspecto ideológico daquilo que foi exposto", ${ }^{155}$ segundo o nexo narrativo da peça.

Ao trazer os elementos "secundários" do teatro e dos espetáculos populares para $\theta$ lugar de destaque da encenação, Eisenstein, em Mudrec, dialoga com a perspectiva vigente na Proletkult sobre a construção de uma nova forma artística ligada diretamente às formas culturais de entretenimento da classe proletária. A significação das peças construídas pelos princípios da montagem de atrações é dada a partir de sua construção e também pela maneira como os materiais da peça - as atrações - se relacionam entre si e

\footnotetext{
${ }^{153}$ Segundo a perspectiva de Peter Szondi, a partir da virada do século XIX para o século XX a estrutura dramática baseada nas narrativas do cotidiano burguês passa a entrar em crise, exemplo disso são as propostas cênicas que surgem das experiências teatrais de Meyerhold e Brecht. Dentro de todas essas propostas cênicas de vanguarda do século XX, a estética do happening é a que mais rompe com as estruturas do drama. Seu surgimento serviu para quebrar o gesso da arte dramática que petrificava as manifestações artísticas banalizadas pelo mercantilismo. As experiências vanguardistas do início do século XX abandonam por completo a estrutura dramática tradicional que é fundamentalmente narrativa. $O$ roteiro passa a se pautar por ações a serem executadas, no entanto, sem estabelecer uma ordem bem determinada para elas. O tempo e o lugar da representação não são definidos como no drama burguês. A atuação é performática e as ações são realizadas de improviso. Os elementos cênicos ganham valor, dando aos objetos uma importância maior ou igual à do ator. A quarta parede do teatro italiano é derrubada e os intérpretes estabelecem maior contato com o público, misturando ficção e realidade. Sobre este ponto ver SZONDI, Peter, Teoria do drama moderno [1880 1950], Trad. Luiz Sérgio Repa, São Paulo, Cosac \& Naify, 2001, pp. 89-101, 133-139.

${ }^{154}$ EISENSTEIN, Sergei, Montagem de Atrações, p. 189.

155 Idem
} 
com o público. A ênfase dada à ação física, ao impacto psicológico e à agressividade liga a forma de construção mediante atrações ao contexto cultural e político bolchevique, na medida em que "uma montagem de choques permanente no espectador parece querer também exercitar [o espectador trabalhador] para o choque, o conflito, a Revolução". ${ }^{156}$

\section{III: A montagem de atrações no cinema}

Em Монтаж Киноаттракционов ${ }^{157}$ (Montagem de Atrações no Cinema), texto manuscrito que não chegou a ser publicado em vida, datado de 1924, Eisenstein oferece uma apresentação relativamente sistemática e detalhada de suas idéias sobre a montagem de atrações. Trata-se de um texto que permaneceu inédito até o início da década de 1980, além de ser pouco citado pela tradição crítica que se debruçou sobre a obra do diretor. Menos controverso que Método de Realização de um Filme Operário ${ }^{158}$ e mais compreensível que Sobre a Questão da Abordagem Materialista da Forma, ${ }^{159}$ ambos publicados após o lançamento de A Greve, em 1925, Montagem de

\footnotetext{
${ }^{156}$ OLIVEIRA, Vanessa, Op. Cit., p. 56.

${ }^{157}$ EISENSTEIN, Sergei M., "The Montage of Film Attractions", in S. M. Eizenshtein Writings, 1922-34, TAYLOR, Richard (Ed. e trad.), London, BFI Publishing, 1987, pp. 39-58.

${ }^{158}$ EISENSTEIN, Sergei M., "The Method of Making a Worker's Film", in S. M. Eizenshtein Writings, 1922-34, TAYLOR, Richard (Ed. e trad.), London, BFI Publishing, 1987, pp. 65-66.

${ }^{159}$ EISENSTEIN, Sergei M., "The Problem of the Materialist Approach to Form", in S. M. Eizenshtein Writings, 1922-34, TAYLOR, Richard (Ed. e trad.), London, BFI Publishing, 1987, pp. 59-64.
} 
Atrações no Cinema disserta sobre as possibilidades da aplicação de esquemas de atrações no cinema, diferenciando-o do trabalho proposto por Dziga Vertov (1896-1954) ${ }^{160}$ - cineasta, documentarista, e um dos principais expoentes da vanguarda construtivista russa -, caracterizado pela proposta estética do Кино-глаз ${ }^{161}$ (cine-olho), que defendia um modelo de cinema fundado estritamente no trabalho documental e na montagem de imagens tomadas de improviso do cotidiano.

A definição de atração neste texto oferece algumas diferenças em relação àquela dada no manifesto Montagem de Atrações, publicado no jornal da Frente Esquerda das Artes (LEF) - principal veículo de comunicação das propostas artísticas construtivistas -, em 1923. A atração deixa de ser um elemento esteticamente agressivo do teatro $-{ }^{162}$ de acordo com a definição anterior, presente em Montagem de Atrações - e passa a ser considerada, no plano cinematográfico, como qualquer evento real filmado (ação física do ator, objetos captados pela objetiva, etc.) capaz de exercer uma pressão psicológica no público. A atração adaptada ao âmbito fílmico pode ser qualquer elemento do plano, material ou plástico, todavia, esse elemento deve se relacionar com a realidade histórica e com o cotidiano do espectador. ${ }^{163}$

\footnotetext{
${ }^{160}$ Para uma apresentação da divergência entre Eisenstein e Vertov ver PETRIC, Vlada, Constructivism in Film: The Man with the Movie Camera: A Cinematic Analysis, Cambridge, Cambridge University Press, 1987, pp. 67-69.

${ }^{161}$ Sobre este tema, ver VERTOV, Dziga, O'BRIEN, Kevin (trad.), MICHELSON, Annette (ed.), Kino-eye: The Writings of Dziga Vertov, Berkley, Ca, University of California Press, 1984.

162 "Uma atração [...] é qualquer aspecto agressivo do teatro, isto é, qualquer elemento teatral que sujeita o espectador a um impacto sensorial ou psicológico [...]". EISENSTEIN, Sergei, "Montage of Attractions: For 'Enough Stupidity in Every Wiseman'", Daniel Gerould (trad.), in The Drama Review: TDR, Vol. 18, No. 1, The MIT Press, 1974, p. 78.

${ }^{163} \mathrm{Em}$ certa medida, o aspecto excêntrico das atrações propostas por Eisenstein remete à noção de estranhamento (ostranenie) de Viktor Chklovskii (1893-1984). Este conceito parte do pressuposto de que a percepção sensorial do homem moderno seja automatizada, pois os hábitos cotidianos (relações sociais, trabalho, etc.) são brutalmente padronizados, e assinala que a fruição estética possui a capacidade de combater os reflexos autômatos que regem o
} 
É importante salientar que a justaposição de fragmentos de montagem (que podem funcionar como atrações), proposta pela montagem de atrações, não abrange a definição de síntese dialética da montagem intelectual - noção desenvolvida por Eisenstein, por volta dos anos de 1928-29. A proposta do "cinema intelectual" compreende os fragmentos fílmicos e suas irrupções, como ferramentas capazes de gerar, na mente do espectador, conceitos abstratos a partir dos signos presentes na imagem cinematográfica. De modo distinto, na teoria da montagem de atrações as seqüências são ordenadas a fim de criar um efeito comparativo: mostrar as peculiaridades e os diferentes pontos de vista de um mesmo acontecimento narrado. Embora Eisenstein afirme que o efeito comparativo das atrações advenha da justaposição de fragmentos e da descontinuidade das seqüências, não se pode dizer, a partir da perspectiva apresentada em Montagem de Atrações no Cinema, que essa justaposição tenha por fim a construção de conceitos mediante imagens. De acordo com o historiador François Albera, Eisenstein, em Dramatugia da Forma do Filme texto de 1929 que apresenta uma síntese de suas considerações sobre o cinema intelectual -, "ao colocar na base do fenômeno do cinema uma realidade óptico-técnica, a da superposição ${ }^{164}$ de duas imagens - e não sua sucessão (a perspectiva da montagem de atrações) -, (Eisenstein) pode situar a categoria genérica de conflito e dela inferir uma definição da prática

comportamento subjetivo cotidiano. A constatação da existência de tal "efeito estético", pode-se dizer, foi suficiente para que os construtivistas russos (incluindo Eisenstein) considerassem a arte como ferramenta capaz de combater os elementos nocivos da experiência cotidiana moderna. RUSSO, Eduardo, "La máquina de pensar: Notas para una genealogía de la relación entre teoría y prática em Sergei Eisenstein“. In: Cuadernos del Centro de Estudios en Diseño y Comunicación, № 15, ImprentaKurz, 2002, p. 62-63

${ }^{164}$ Impressão de duas ou mais imagens distintas, mediante exposição múltipla. 
significante no cinema como tripla dinamização - do material [...], do emocional e do intelectual". ${ }^{165}$

Combinadas e calculadas, as atrações podem, para o diretor, concentrar a emoção do público a ponto de direcioná-la para um fim específico: comoção, agitação, politização, etc. Para tanto, o filme não pode se restringir a uma mera apresentação de acontecimentos filmados, que se desenvolvem no interior de seu universo ficcional, ou encadeamento de cenas permeadas por um drama: ele deve selecioná-los de maneira judiciosa, moldando a consciência do espectador de acordo com um propósito socialmente justificado. Todavia, trabalhar atrações visando um público abstrato e universal levaria a uma "arte pela arte", na medida em que o efeito das atrações se perderia nas diferentes percepções de mundo das classes sociais. O cálculo das atrações, portanto, só é possível quando o público é, de antemão, conhecido e selecionado.

Ao estabelecer o caráter articulado das atrações e da realidade histórica e social do espectador ${ }^{166}$ como fatores cruciais para o desenvolvimento da cinematografia revolucionária, Eisenstein coloca-se em clara divergência com Vertov sobre a questão da recepção fílmica. O cineasta não compartilha com Vertov a crença de que as imagens captadas pela câmera, por si, sejam capazes de penetrar a realidade e revelar ao espectador os significados

\footnotetext{
${ }^{165}$ ALBERA, François, Eisenstein e o Construtivismo Russo, trad. Eloísa Araújo Ribeiro, pref. Luiz Renato Martins, São Paulo, Cosac \& Naify Edições, 2002, pp. 271-272. (itálicos, negritos e parênteses meus).

${ }^{166}$ Para Eisenstein, o cinema e o teatro só adquirem sentido enquanto formas de pressão sobre o público. Embora os métodos de construção das duas artes sejam distintos, o cineasta considera que cinema e teatro possuem um dispositivo em comum: a montagem de atrações. A preocupação principal da montagem de atrações é a resposta fisiológica e emocional do espectador, e em que medida essa resposta pode ser trabalhada, a fim de influenciar 0 espectador, tendo em vista sua vivência cotidiana, sua classe social, etc. EISENSTEIN, Sergei M., "The Montage of Film Attractions", in S. M. Eizenshtein Writings, 1922-34, TAYLOR, Richard (Ed. e trad.), London, BFI Publishing, 1987, pp. 39-40.
} 
implícitos nos eventos da realidade empírica e da vida cotidiana. ${ }^{167}$ Para o documentarista, há a necessidade de que o registro das imagens (processo de filmagem) não interfira na dinâmica dos fatos filmados. O cotidiano precisa ser filmado sem que haja a consciência da existência de uma filmagem Por essa razão, Vertov era radicalmente contra o cinema ficcional: os ditos "filmes encenados". ${ }^{168}$ Para ele, a encenação era um elemento artificial imposto à realidade, que contrastava com a forma pela qual o real era percebido pelo espectador. Pelo fato de Vertov ser essencialmente um documentarista, sua teoria do Кино-глаз guarda um profundo interesse pela veracidade da imagem fílmica. Na sua concepção, os fotogramas que compõem cine-fatos - recortes de planos enquadrados pela câmera - não extraem a verdade histórica subjacente aos fatos captados pelo processo de filmagem. Os cine-fatos são a matéria-prima do processo de busca da verdade. A função do cineastaengenheiro, para Vertov, é reorganizar fragmentos fílmicos por meio da montagem, utilizado associações rítmicas e espaciais, a fim de construir uma apresentação dos fatos capaz de ser apreendida pelo espectador. ${ }^{169}$

Considerando que a imagem cinematográfica, ao contrário da encenação teatral, não apresenta um fato em sua totalidade, mas representações e recortes destes fatos, Eisenstein observa que a aplicação da

\footnotetext{
167 O cinema-olho de Vertov é acima de tudo um método para captar particularidades do cotidiano em caráter de urgência. De acordo com sua perspectiva, filmar é absorver a realidade dos fatos e apresentá-la aos olhos do espectador, constituindo-se como uma "ferramenta epistemológica" que contribui para potencializar a percepção visual humana. A introdução da câmera na realidade a ser filmada não deve alterar a própria composição dessa realidade. Assim sendo, a inserção de elementos ficcionais em um filme (encenação, atuação, trabalho de direção, etc.) distorce o conteúdo "factográfico" da imagem cinematográfica. Sobre este ponto ver PETRIC, Vlada, Constructivism in Film: The Man with the Movie Camera: A Cinematic Analysis, Cambridge, Cambridge University Press, 1987, pp. 1-69.

168 VERTOV, Dziga, "The Factory of Facts and Other Writings", Kevin O'Brien (trad.), in October, Vol. 7, Soviet Revolutionary Culture, MIT Press, Winter, 1978, pp. 109-128

${ }^{169}$ Idem, p. 114.
} 
montagem de atrações torna-se mais eficiente no cinema do que no teatro. Em seu método construtivo, para cada fenômeno que o cinema apresenta, faz-se necessária uma comparação, um recorte, uma apresentação sob ângulos fotográficos diferentes. Um fragmento da narrativa, que pode ser apresentado facilmente no teatro pela interpretação do ator, exige no cinema uma sucessão variada de planos. Se um efeito (afecção) no teatro é obtido principalmente através da percepção "física" de uma ação encenada (por exemplo, o horror que a cena de um assassinato pode causar), no cinema, este efeito necessitaria de uma justaposição e de uma acumulação de fatos na psique do público, a partir dos elementos que compõem o evento apresentado (neste caso, todos os momentos que engendram um homicídio: a perseguição, o assassinato, a ocultação do cadáver, etc.). Os efeitos do cinema apenas são obtidos com a percepção do todo, nas seqüências de atrações montadas a partir de fragmentos cinematográficos. A atração, por si só, apenas arrebata momentaneamente a atenção do público. Somente a justaposição das atrações é capaz de gerar um efeito útil para uma determinada trama ou para ilustrar o tema de um filme, de acordo com a intenção da direção.

O fator crucial do processo de composição das atrações, para Eisenstein, não reside apenas na escolha dos elementos materiais que compõem a seqüência de atrações, mas na cadeia de associações que é tecida na mente de um público em particular, a relação com sua classe, a verossimilhança (ou a recusa do verossímil) estabelecida entre as atrações e os fatos reais, etc. A estrutura de comparação/conflito da montagem de atrações não deve ser confundida com a da montagem paralela dos kinopravda de Vertov, que apresentam o tema de um documentário como um 
princípio narrativo. De acordo com Eisenstein, o principal problema do método construtivo de Vertov reside no fato de que seus filmes não utilizam a descontinuidade da montagem para captar a atenção do público. O método da montagem de atrações no cinema, ao contrário, utiliza a descontinuidade dos fragmentos e dos elementos fílmicos para comparar assuntos presentes na narrativa. ${ }^{170}$

\section{IV: As possibilidades criativas do cinema ficcional.}

Ainda em Montagem de Atrações no Cinema, Eisenstein afirma que a ruína da maioria dos filmes russos de ficção (lançados na primeira metade da década de 1920) advém da incapacidade dos diretores de construírem conscientemente esquemas de atrações. Para ele, as raras atrações que estes diretores conseguiram obter foram fruto de repetições de clichês de sucessos

\footnotetext{
${ }^{170} \mathrm{Em}$ A Greve, por exemplo, Eisenstein utiliza tipos diferentes de atuação teatral para diferenciar os operários e seus inimigos de classe: capitalistas, burocratas, a polícia, etc. A ação cênica dos inimigos do proletariado segue tendências que transitam entre o realismo (a polícia), o caricatural (os capitalistas e seus lacaios), o grotesco (os espias animalescos) e o circense (o rei vagabundo e seu séquito). Em contrapartida, os trabalhadores grevistas são representados por uma atuação baseada no "realismo heróico" (designação genérica utilizada pela crítica para um estilo teatral adotado nos primeiros filmes russos após a revolução de 1917, baseados no teatro realista) que por sua vez, exclui quaisquer exageros de vestuário ou de atitude. As personagens operárias são tratadas de modo a apresentar as características da classe proletária enquanto sujeito histórico da luta de classes. Sobre este assunto, ver KOLCHEVSKA, Natasha, "From Agitation to Factography: The Plays of Sergej Tret'jakov", in Slavic and East European Journal, Vol. 31, No.3, Lexington, KY, American Association of Teachers of Slavic and East European Languages, 1987, pp. 388-403. Ver também BORDWELL, David, The Cinema of Eisenstein. Cambridge, MA, Harvard University Press, 1996, pp. 140-141.
} 
de bilheteria, principalmente de filmes americanos importados durante 0 estabelecimento da Novaya Ekonomiceskaya Politika (Nova Política Econômica - NEP). Embora Eisenstein admita que a cinematografia americana possa oferecer um material considerável para o trabalho com atrações, ele adverte que não se deve fazer uma transposição do método de composição cinematográfica americano para a Rússia, mas um treinamento na seleção de atrações a partir do "material cru" da realidade histórica e cotidiana russa.

Considerando o poder de influência que os filmes de ficção, em outras palavras, filmes encenados, exercem sobre as massas, Eisenstein afirma em Montagem de Atrações no Cinema que este gênero é o mais efetivo para a tarefa social da arte cinematográfica. E ainda mais: afirma também que não deveria haver outro tipo de cinema senão o cinema de agitação! Portanto, aperfeiçoar os elementos específicos desse gênero, para ele, é a "ordem do dia" na agenda do cinema revolucionário. E o primeiro ponto que ele elege para a discussão diz respeito à questão do roteiro.

A presença ou ausência de roteiro, na perspectiva apresentada por Eisenstein neste texto, não faz diferença substancial na composição de um filme. O roteiro no método da montagem de atrações, baseado ou não em uma narrativa dramática, é uma lista (ou prescrição) de seqüências de montagem e combinações que o escritor/diretor/roteirista constrói para seu público. Para o cineasta, a seleção dos fragmentos de montagem (fotogramas que comporão as seqüências fílmicas) presentes no roteiro deve seguir "a lógica da razão de ser do cinema, um instrumento de pressão psicológica sobre o espectador". ${ }^{171}$

\footnotetext{
${ }^{171}$ EISENSTEIN, Sergei M., "The Montage of Film Attractions", in S. M. Eizenshtein Writings, 1922-34, TAYLOR, Richard (Ed. e trad.), London, BFI Publishing, 1987, p. 41.
} 
Os recursos estilísticos do filme e as técnicas de narração não podem ser pensados enquanto objetos estéticos autônomos, mas como ferramentas para a ação social. Se uma obra cinematográfica não afeta emocionalmente seu espectador, se ela não oferece, no interior de sua narrativa, uma reflexão materialista sobre as particularidades de um processo histórico, e se, acima de tudo, ela não impele o público a participar ativamente da luta de classes, ela perde, na visão do cineasta, sua razão de ser no seio da cultura revolucionária

Para Eisenstein, o fator decisivo para a seleção e apresentação dos fragmentos fílmicos é a economia de recursos para construir o efeito da associação. Segundo o cineasta, uma associação construída a partir de uma seqüência longa, formada por muitos fragmentos, é suscetível de confusão por parte do público. A repetição de tomadas, de acordo com sua perspectiva, deve ser evitada e cada elemento deve ser apresentado, se possível, de apenas um ângulo, respeitando a especificidade material do fato ou evento apresentado.

Por fim, Eisenstein considera que é necessário combater as posturas reducionistas que levam a arte cinematográfica a uma apresentação da "vida real" baseada na exaltação do "material cru", do fragmento fílmico tomado de imediato, não construído esteticamente. ${ }^{172}$ Para o cineasta, a montagem de atrações aplicada ao cinema, é também uma demonstração da vida real, mas de uma realidade posta em questão, permeada de significação histórica e material. A estetização dos fragmentos da "vida real", fruto da canonização do

\footnotetext{
${ }^{172}$ Alexei Gan, um dos primeiros teóricos construtivistas, fundamentava suas convicções sobre a arte cinematográfica nos trabalhos de Vertov e de nos documentários de Esfir Shub (18941953). De acordo com Albera, Gan considerava o cinema não ficional como o modo de expressão cinematográfico construtivista por excelência e desqualificava, a priori, todo procedimento fílmico proveniente de um trabalho com a ficção, tais como a montagem de atrações de Eisenstein e a montagem-manipulação de Lev Kuleshov (1899-1970). ALBERA, François, Op. Cit., p. 212-218.
} 


\section{5}

material cru, e do instante não decupado, como o única via aceitável para uma apresentação da vida cotidiana, joga fora as possibilidades criativas do cinema ficcional. 


\title{
QUAR'TO CAPÍ'TULO
}

\author{
Stachka (A Greve)
}

\section{I: Um ensaio sobre os antagonismos}

Pode-se dizer que A Greve (Stachka - URSS, 1925) estabelece o modelo que Eisenstein seguiu, de diversas maneiras, em todos os seus filmes mudos. Neste filme, o cineasta põe em prática seu projeto de atribuir um caráter épico a história revolucionária soviética das décadas de 1910 e 1920 . É o início de uma investigação sistemática da "linguagem cinematográfica" a partir das técnicas de montagem desenvolvidas por Lev Kuleshov (1899 1970), Vsevolod Pudovkin (1893 - 1953) e Dziga Vertov (1896 - 1954), sendo auxiliado pela câmera de Eduard Tissé $(1897$ - 1961) e pela assistência de Grigori Alexandrov (1903 - 1983). A importância histórica desta obra não reside apenas na sua complexa construção fílmica e na sua teatralidade excêntrica é necessário ressaltar, Stachka é uma obra de agitação política. Trata-se de um filme que pretende atuar como um mediador de forças sociais, como trabalho artístico que tenciona intervir diretamente na luta de classes. É uma obra que pressupõe uma "encomenda social", trabalha sua forma a partir das especificidades dessa encomenda e estabelece um diálogo estreito com o espectador. Constitui-se, nesse sentido, como uma aplicação da teoria da montagem de atrações no cinema. ${ }^{173}$

\footnotetext{
${ }^{173}$ A teoria da montagem de atrações foi inicialmente desenvolvida pelo diretor como método construtivo para o teatro, durante seus trabalhos no teatro operário da Proletkult entre os anos
} 
O filme trata das lutas operárias anteriores à revolução de outubro. Seu "roteiro" baseia-se em episódios das grandes greves de 1903, que ocorreram em Rostov-on-Dov e outros distritos industriais, estendendo-se por mais de quinhentas fábricas de diversos setores, com a participação de cerca de quinhentos mil trabalhadores. Todavia, não há referências diretas durante 0 decorrer do filme, que foi rodado nas periferias de Moscou, à lugares e à personalidades, exceto no letreiro final. Eisenstein, sem trair a especificidade dos acontecimentos históricos, pretendeu evitar uma crônica dos fatos, elaborando, na narrativa, uma anatomia das forças que então se confrontaram.

O enredo de $A$ Greve, em síntese, conta como operários bolcheviques de uma fábrica, na Rússia czarista pré-revolucionária, após prepararem um trabalho de agitação, convertem um protesto espontâneo em uma greve. Todavia, ao contrário de trabalhos de outros cineastas soviéticos da época, como Pudovkin (que baseava seu método de composição cinematográfica no modelo americano) Eisenstein não utiliza a evolução da trama ${ }^{174}$ para envolver o espectador. O tema é apresentado, de modo sintético, no primeiro letreiro após os créditos. Ao citar Lênin já na primeira seqüência do filme - "A força da

de 1923 e 1924. Influenciada pelo trabalho dramatúrgico que Sergei M. Tret'iakov (1892-1937) já havia desenvolvido nas peças de Vsevolod Meyerhold (1874-1940), e também pela sociologia da arte de Boris Arvatov (1896-1940), a proposta da montagem de atrações foi o desdobramento de um modelo racional de avaliação e controle das afecções motivadas por um espetáculo teatral em sua platéia.

O termo "montagem de atrações" apareceu pela primeira vez em manifesto escrito por Eisenstein, na revista da Frente Esquerda das Artes (LEF), em 1923. Nele, o diretor apresenta sua avaliação do processo de criação de $O$ Sábio - adaptação da peça de Aleksandr Ostrovky (1835-1940) feita pelo teatro operário do Proletkul't - e descreve em linhas gerais a proposta de um "teatro de atrações". Tratava-se de um novo tipo de espetáculo para o público soviético, elaborado a partir de formas da cultura popular urbana: o cabaré, o music-hall, cinemaburlesco, etc. Sobre este ponto, ver TRET'IAKOV, Sergei, "The Theater of Attractions", in OCTOBER 118, Fall 2006, Cambridge, MA, MIT Press, PP. 19-26.

${ }^{174}$ Trama é o encadeado de ações executadas ou a executar pelas personagens numa ficção, a fim de criar sentido ou emoção no espectador. Pode-se dizer que a trama é a estrutura da narrativa, aquilo que dá sustentação à história, ao desenrolar dos acontecimentos. Sobre este assunto ver SHKLOVKSY, Victor, Theory of Prose, Champaign, Dalkey Archive Press University of Illinois, 1991. 
classe proletária está em sua organização [...] Organização quer dizer unidade de ação, unidade de atuação prática" -, o diretor apresenta ao seu público o nexo que amarra as diversas etapas da narrativa.

Cada parte de Stachka se apresenta como uma representação de diferentes etapas de uma greve, pensada estruturalmente: as condições de trabalho que levam a os operários a se revoltar, os conflitos com a gerência da fábrica, a negociação com os acionistas, a repressão policial, etc. Eisenstein aproveitou uma limitação da capacidade de projeção das salas de cinema da época, que contavam, em sua maioria, com apenas um projetor, para reforçar a indicação da mudança das fases no enredo a fim de sintetizar os elementos da trama e facilitar a compreensão do espectador. Stachka divide-se em seis rolos.

O primeiro rolo, que começa com o letreiro: "Tudo está tranqüilo na fábrica / MAS...", apresenta o processo de agitação dos trabalhadores revolucionários e, em contraste, o trabalho de espionagem da polícia, que trata de obter o máximo de informações possíveis sobre os agitadores. O segundo rolo, intitulado "A causa imediata da greve", narra o roubo de um micrômetro, sob os cuidados do operário que o manuseava, a reação enérgica da direção da fábrica em relação ao fato ocorrido e o suicídio do operário injustamente acusado de roubar o equipamento. A morte na fábrica desencadeia a revolta que desemboca na greve fomentada pelo trabalho de agitação narrado no primeiro rolo. O terceiro rolo se inicia com o letreiro "A fábrica permanece parada" e narra os efeitos da inatividade da fábrica nos trabalhadores e nos capitalistas. O quarto rolo, "A greve se prolonga", expõe o desgaste dos 
trabalhadores na medida em que os impasses da greve continuam. Nesta parte, Eisenstein nos apresenta um dos elementos chave para o enredo do filme: a traição de um dos líderes da greve. O quinto rolo "Fabricação de um massacre", narra um ato de provocação arquitetado pelas forças contrarevolucionárias, que desencadeia a repressão policial e o início da derrota do movimento grevista. Um espião policial contrata uma "trupe" de vagabundos para sabotar uma manifestação do movimento grevista. Os "provocadores" contratados falham em sua tentativa de sabotagem e, no meio da confusão gerada, iniciam um incêndio numa tenda de vodka. Bombeiros que, em princípio, deveriam combater o fogo, dirigem jatos de água contra os grevistas, contribuindo para a captura do principal líder do comando de greve.

No último rolo, intitulado "Liquidação", Eisenstein amplia o impacto emocional da ação dramática, apresentando um desfecho sangrento para a narrativa. Na última fase da trama, temos a seqüência na qual o líder grevista capturado dá prova de bravura, enfrentando o suborno e as ameaças de tortura de seus captores e em seguida, uma cena que mostra o ataque de oficiais cossacos às habitações dos operários. Ao massacre, segue-se uma seqüência construída por meio de montagem paralela, que concatena duas ações: 1) cossacos abrindo fogo contra uma multidão de operários; 2) açougueiros sacrificando um touro.

A montagem apresentada por Eisenstein é claramente não diegética ${ }^{175}$. Sua construção remete diretamente aos princípios da montagem de atrações,

\footnotetext{
${ }^{175}$ Grosso modo, a diegese é o efeito de realidade da narrativa (em outras palavras: "o mundo ficcional", à parte da realidade do leitor ou do espectador). $O$ tempo diegético e o espaço diegético são, deste modo, o tempo e o espaço que decorrem ou existem dentro da trama, com suas particularidades, limites e coerências determinadas pelo autor da obra. Sobre este ponto,
} 
trata-se de uma atração formalmente dissociada do restante do filme, mas que opera para intensificar a "carga emocional" da seqüência anterior. Pode-se dizer que o último rolo é praticamente um curta-metragem separado do restante da película, uma montagem de atrações livres, que, ao se desenrolar de forma independente da narração do filme, provoca o espectador, apelando para a dramaticidade da ação (uma multidão sendo massacrada) na medida em o instiga a refletir sobre a descontinuidade da seqüência e a sua relação com as outras etapas do processo grevista, mostrada nas partes anteriores.

Deste modo, Eisenstein apresenta, em Stachka, a anatomia de um processo político, todavia, sem estabelecer relações diretas com os fatos históricos que ocorreram nos movimentos grevistas de 1905 (exceto no final do filme, no último letreiro). O argumento esquematiza as fases, os desafios, e as crises pelas quais uma greve pode passar e efetua uma leitura das forças com as quais a classe trabalhadora deve travar embate. Stachka não idealiza as forças da luta de classes, ao contrário, apresenta os vários atores políticos que participam das forças revolucionárias e contra-revolucionárias, utilizando o drama, a estilização e oposições de caráter temáticas (uma ação política específica e seu contrário, por exemplo). ${ }^{176}$

As seqüências do filme estabelecem um grande número de antagonismos entre os operários e seus inimigos de classe: capitalistas, burocratas, polícia, etc. Todas essas forças vêm apresentadas seguindo uma

ver BORDWELL, David, Narration in the Fiction Film, Madison, University of Wisconsin Press, 1985.

${ }^{176}$ Ver BORDWELL, David, The Cinema of Eisenstein, Cambridge, MA, Harvard University Press, 1996, p.74. 
variedade de tipos de atuação teatral, ${ }^{177}$ desenvolvidas pelo teatro russo tradicional (a partir do método de construção de personagens desenvolvido por Constantin Stanislavski, (1863-1938) - e pela escola teatral construtivista (a partir de uma revisão da teoria da biomecânica de Vsevolod Meyerhold. ${ }^{178} \mathrm{~A}$ ação cênica das personagens inimigas do proletariado segue tendências que transitam entre o realismo (a polícia), o caricatural (os capitalistas e seus lacaios), o grotesco (os espias animalescos) e o circense (o rei vagabundo e seu séquito). Em contrapartida, os trabalhadores grevistas são representados mediante um tipo de atuação baseada no "realismo heróico" (designação genérica utilizada pela crítica para um estilo teatral adotado nos primeiros filmes russos após a revolução de outubro de 1917) que, por sua vez, exclui quaisquer exageros de vestuário ou atitude. $\mathrm{Na}$ abertura do filme, o cineasta despersonaliza os agitadores: após o primeiro plano frontal do diretor da fábrica, eles aparecem em ângulos de câmera oblíquos, como silhuetas e sombras, transitando rapidamente por lugares da fábrica não identificados (fig. 1 a fig. 6).

\footnotetext{
${ }^{177}$ Embora possa parecer contraditória, a apropriação de estilos teatrais incompatíveis (ou até mesmo antagônicos) que Eisenstein efetua em Stachka, tem o intuito de fortalecer a distinção entre as personagens que caracterizam as forças revolucionárias e as contra-revolucionárias. É necessário ressaltar que ambas as técnicas de atuação foram adaptadas a partir da noção de "movimento expressivo", desenvolvida por Eisenstein, com base no trabalho científico (no campo da fisiologia do trabalho) do poeta Aleksei Gastev (1882-1939). Sobre a noção de "movimento expressivo", ver a parte final do ensaio Montagem de Atrações no Cinema, de Eisenstein. EISENSTEIN, Sergei, TAYLOR, Richard (Ed. e trad.), S. M. Eizenshtein Writings, 1922-34, London, BFI Publishing, 1987, pp. 52-58

178 Vsevolod Emilevich Meyerhold (Всеволод Эмильевич Мейерхольд) (28/01/1874 02/021940): diretor de teatro, teórico e ator russo/soviético. Destacou-se como um dos principais diretores de teatro da vanguarda teatral construtivista soviética.
} 
"Agitadores organizam os preparativos da greve"

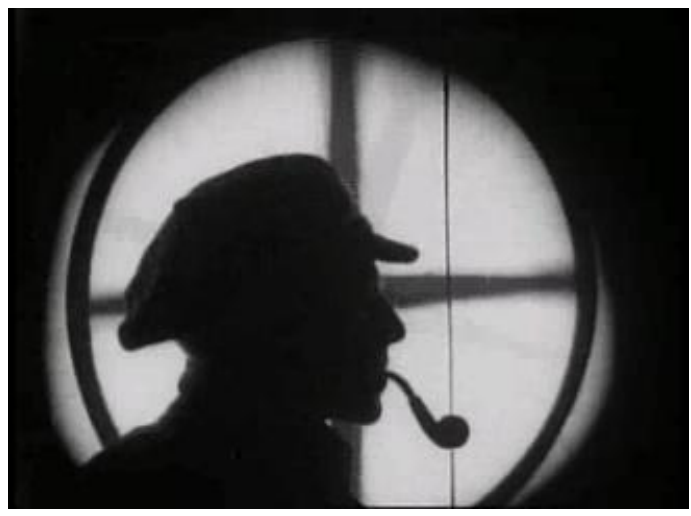

Figura 1

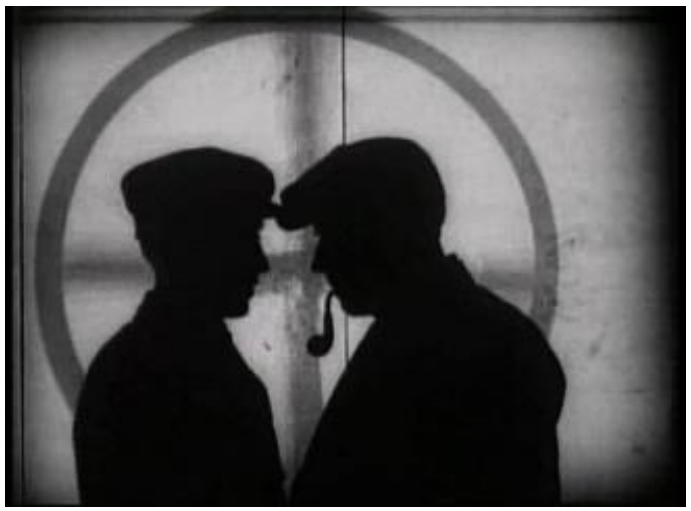

Figura 3

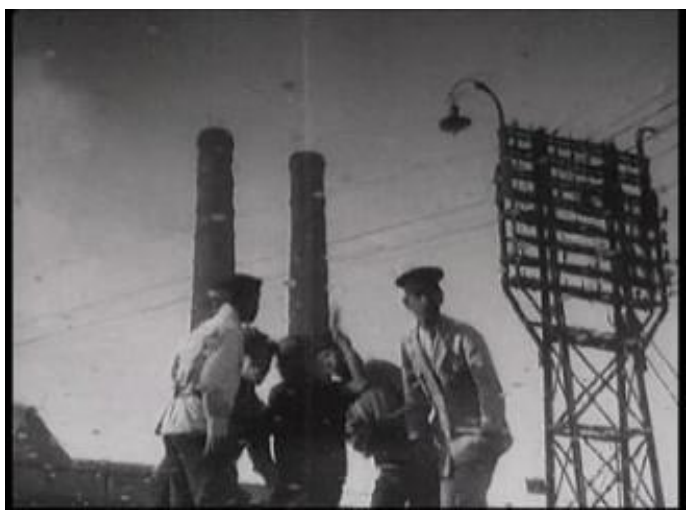

Figura 5

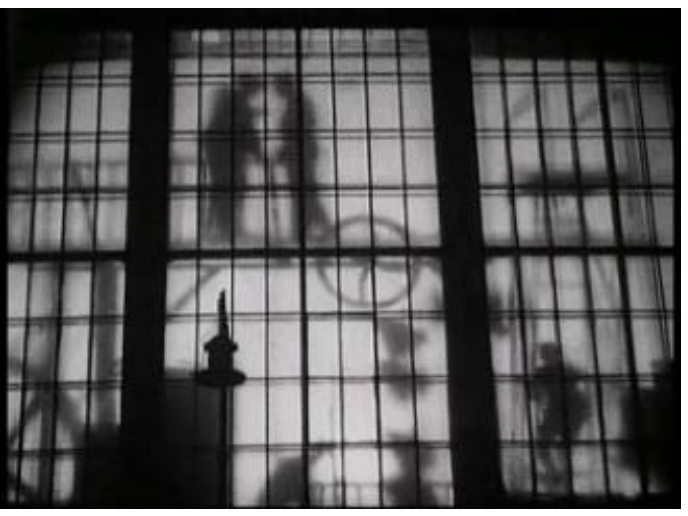

Figura 2

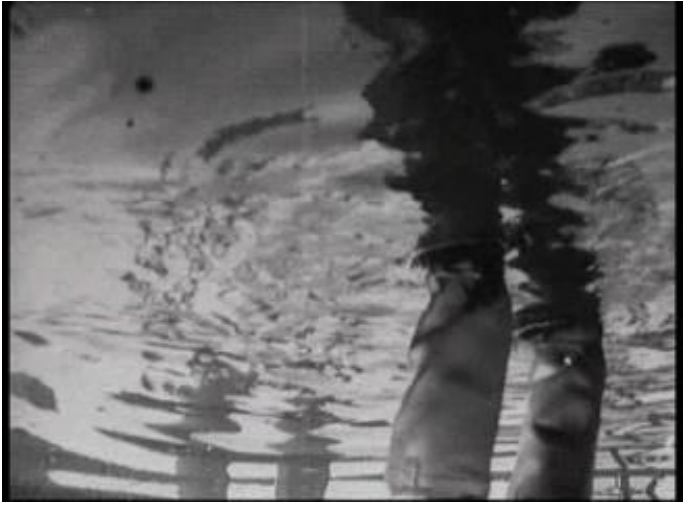

Figura 4

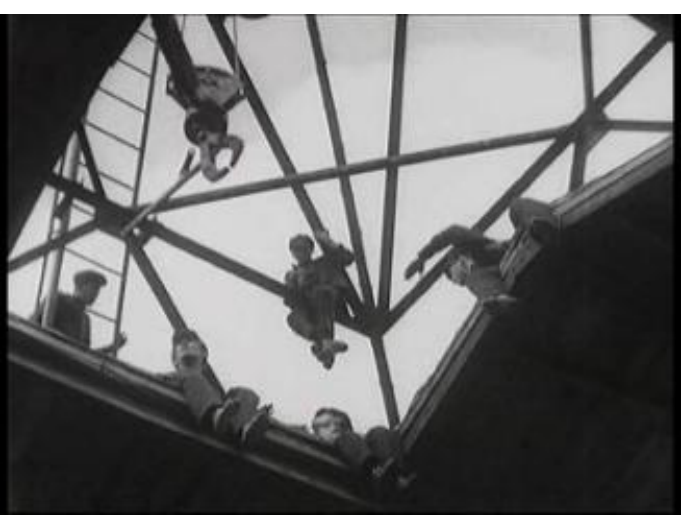

Figura 6 
Toda manifestação individual das personagens operárias funciona, em Stachka, para indicar oposições temáticas que indicam momentos cruciais da trama em torno da luta de classes. O operário que se suicida, angustiado pela falsa acusação de roubo (fig. 25), contrasta com a atitude jocosa dos gerentes da fábrica, que o acusam (fig. 26) (essa seqüência será tratada mais adiante); e a amante de um capitalista (fig.7), que se junta aos policiais que espancam um trabalhador, contrasta com a líder bolchevique anônima (fig.8), que enfrenta a polícia para soar o alarme de incêndio. ${ }^{179}$

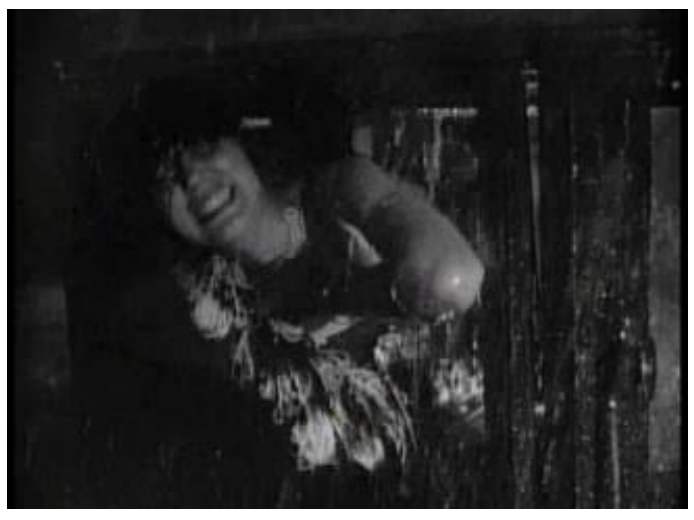

Figura 7

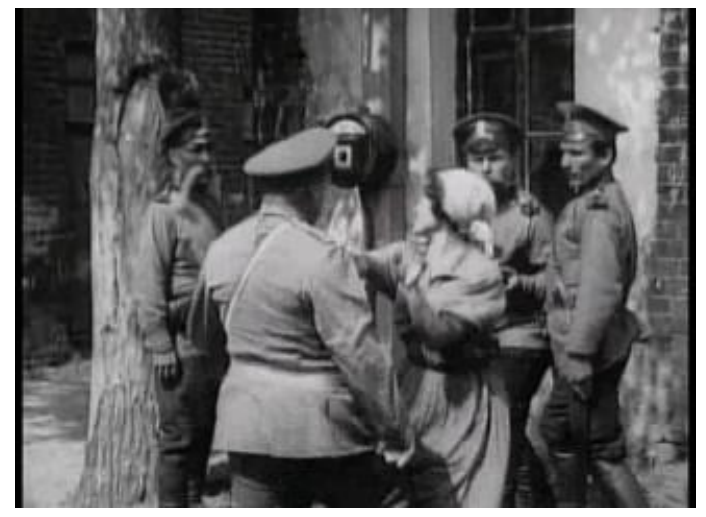

Figura 8

As oposições desenvolvidas por Eisenstein entre os inimigos históricos da classe operária e os trabalhadores grevistas - traduzidas em termos de caricatura grotesca versus "realismo heróico" - são provenientes dos espetáculos de massas do período da guerra civil russa (1917-21). A dinâmica teatral de Stachka é fortemente influenciada pelos agitki, veículos de propaganda que surgiram em torno da revolução de outubro. Nestes

\footnotetext{
${ }^{179}$ Ver BORDWELL, David, Op cit., p. 76.
} 
espetáculos, conferia-se destaque especial às figuras de capitalistas (e demais tipos sociais que se contrapusessem aos interesses dos trabalhadores). Ridicularizadas e bem tipificadas, essas personagens eram trabalhadas com bastante ênfase a fim de mostrar, de maneira clara para o público, quem eram os inimigos da revolução.

Eisenstein utiliza também outros "motivos" para acentuar as oposições geradas pelas situações dramáticas. O cineasta, desde o início do filme, cria diversas associações entre os trabalhadores e as máquinas da fábrica. Já os capitalistas e seus lacaios são relacionados a um sistema burocrático tortuoso. Em uma seqüência, focada na transmissão de informação e de chamadas telefônicas, o cineasta esquadrinha a hierarquia das personagens que se contrapõem à greve: do capataz, passando pelos gerentes, até os altos oficiais de polícia (fig. 9 e 10). Esta dinâmica contrasta com o processo de produção centrado na imprensa e nas máquinas utilizadas pelos agitadores, onde o texto manuscrito (fig. 11) se converte em panfleto (fig. 12 e 13), cujas cópias são transportadas "a toque de caixa" sobre uma locomotiva (fig. 14) - e é a montagem rítmica, utilizada por Eisenstein nessa seqüência, que enfatiza esta comparação temática. Por meio da oposição máquinas $\mathrm{X}$ burocracia, o cineasta procura mostrar ao espectador a distinção marxista entre as forças e as relações de produção. Em Stachka, as comparações estão bem fixadas na estrutura da narração e, na maioria dos casos, são elaboradas por meio da montagem rítmica ${ }^{180}$ ou da montagem paralela ${ }^{181}$. Em suas obras posteriores, o

\footnotetext{
${ }^{180}$ Trata-se de uma forma de montagem praticada por Eisenstein, baseada no comprimento absoluto dos fragmentos da película. O editor monta o filme segundo um padrão de metragem fixo (cortes a cada quatro metros de filme, por exemplo). De acordo com as considerações que Eisenstein apresenta no artigo Métodos de Montagem (Kino chetyrekh izmerenii II), escrito em 1929, pode-se dizer que as montagens métrica e rítmica são técnicas de trabalho
} 
cineasta experimentará construções baseadas na montagem tonal e na

montagem atonal. ${ }^{182}$

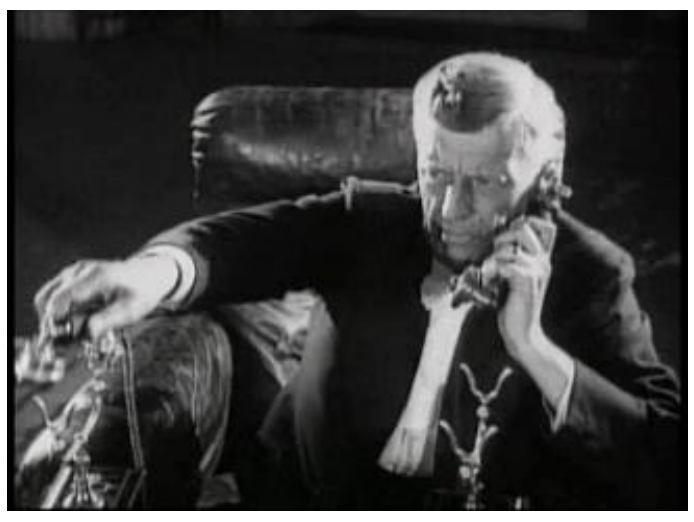

Figura 9

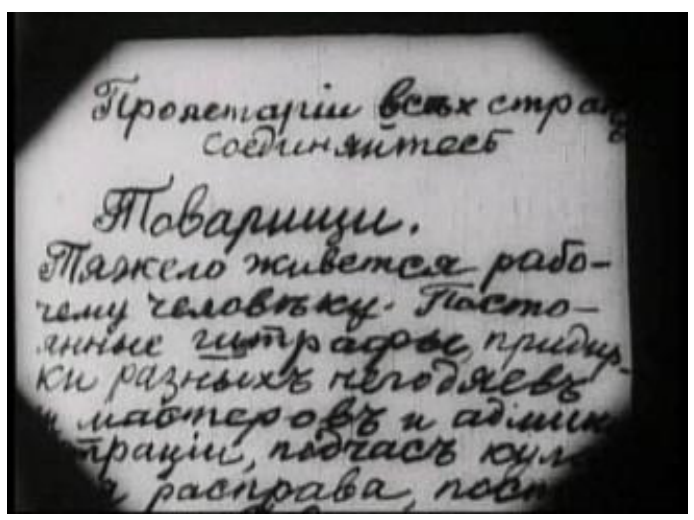

Figura 11

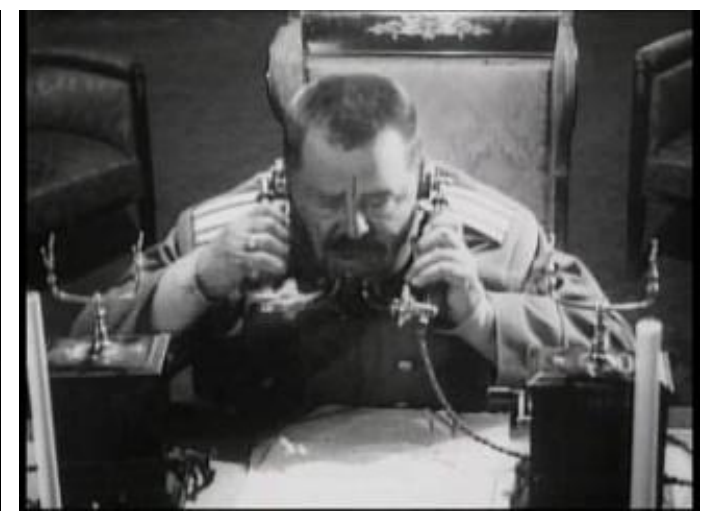

Figura 10

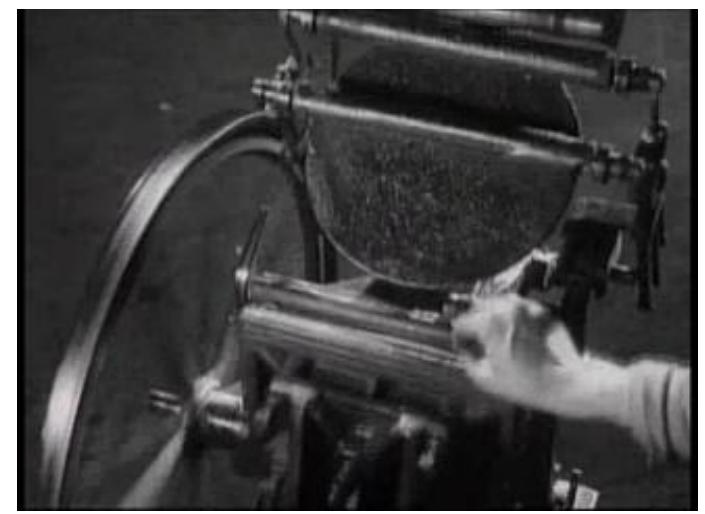

Figura 12

desenvolvidas a partir da experiência cinematográfica soviética na década de 1920, nos obras de Pudovkin e Vertov. Sobre este ponto ver EISENSTEIN, Sergei, A Forma do Filme, Rio de Janeiro, Jorge Zahar Editor, 2002, pp. 80-81. Para uma apresentação sucinta sobre 0 desenvolvimento da montagem soviética na década de 1920 e sua relação com a arte construtivista, ver BORDWELL, David, "The Idea of Montage in Soviet Art and Film", in Cinema Journal, Vol. 11, No. 2, University of Texas Press, 1972, pp. 9-17.

${ }^{181}$ Grosso modo, a montagem paralela é a intercalação de duas seqüências distintas. Esse tipo de montagem é geralmente utilizado quando se pretende estabelecer um uma associação entre as cenas, ou uma aproximação temporal. Seu desenvolvimento é creditado a David Griffith (1875-1948) em Intolerância (Intolerance: Love's Struggle Throughout the Ages, EUA, Dir. David Griffith, 1916).

${ }^{182}$ Eisenstein define as noções de montagem rítmica, tonal e atonal no artigo Métodos de Montagem. Neste texto, o cineasta desenvolve uma tipologia para suas técnicas de montagem, praticadas durante a década de 1920. A técnica de montagem que mais se aproxima da fragmentação imagética presente em $A$ Greve é a montagem rítmica. Ver EISENSTEIN, Sergei, A Forma do Filme, Rio de Janeiro, Jorge Zahar Editor, 2002, pp. 79-84. 


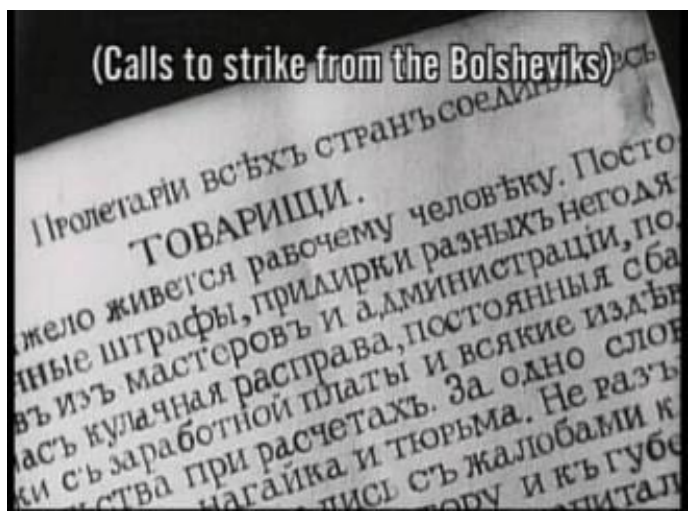

Figura 13

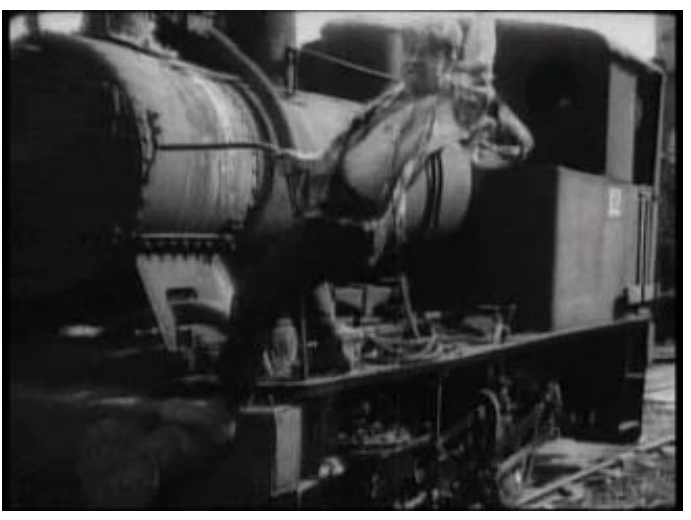

Figura 14

Em diferentes partes de Stachka, Eisenstein utiliza vários motivos visuais para criar associações que reforçam o objetivo de agitação do filme. Três deles - animais, água e círculos - são os motivos mais utilizados pelo diretor, sendo o dos animais, o mais marcante. Nas primeiras cenas, as forças capitalistas são comparadas a animais. Quando a fábrica está parada, seu diretor, em montagem paralela, aparece junto com um corvo e um gato. Todos os espiões da polícia têm codinomes que são conectados visualmente com os animais correspondentes por meio de superposição de imagens (a face do animal com o rosto da araponga, fig.15 e 16) e também pela imitação de alguns reflexos do animal (fig. 17 e 18). Em outra parte do filme, a vida doméstica do proletariado é cercada de animais domésticos: galinhas, porcos, etc., e quando os trabalhadores, no início de sua revolta, expulsam os gestores da fábrica (fig. 19), utilizando de um carrinho de mão, suas crianças, vistas em montagem paralela, repetem o mesmo gesto com uma cabra (fig. 20) Por outro lado, no final do filme, são os operários os que são comparados aos animais: a imagem crua de um touro sacrificado por um açougueiro é associada ao extermínio dos grevistas pelos cossacos (fig. 21 a 24). 


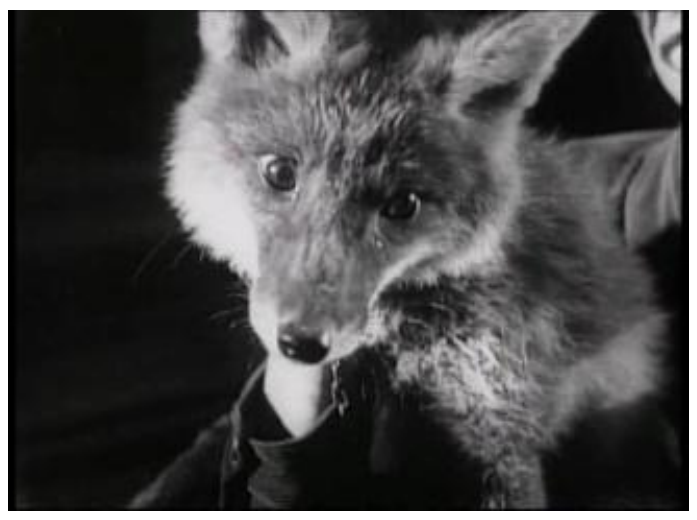

Figura 15

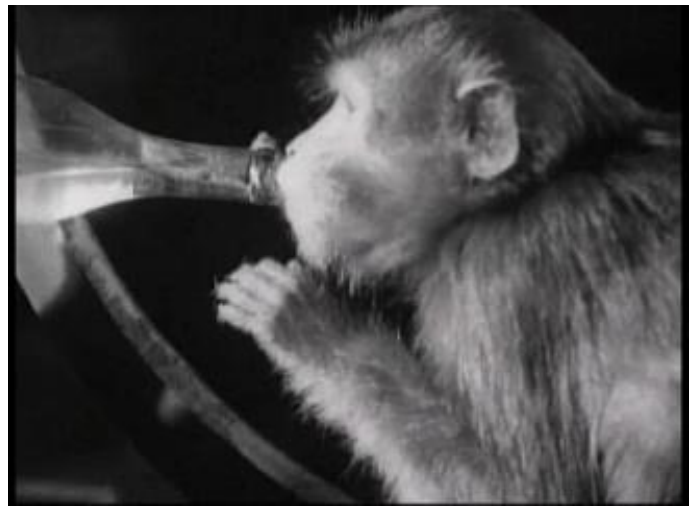

Figura 17

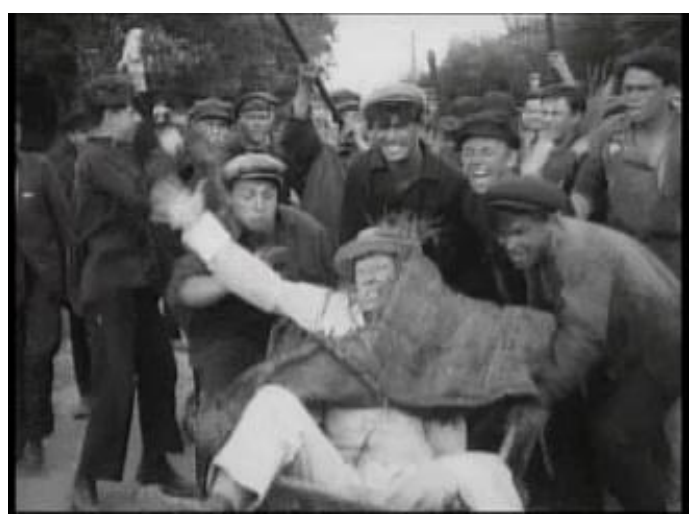

Figura 19

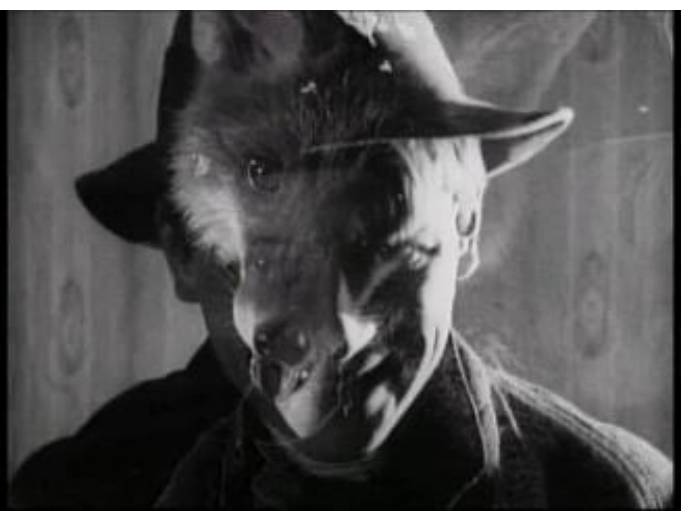

Figura 16

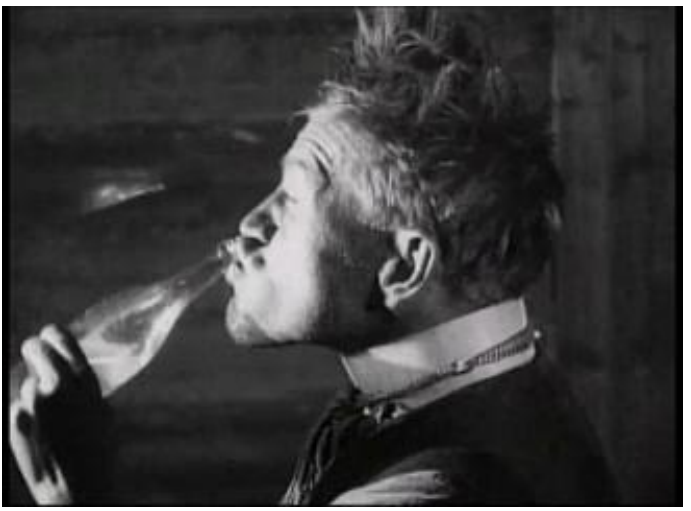

Figura 18

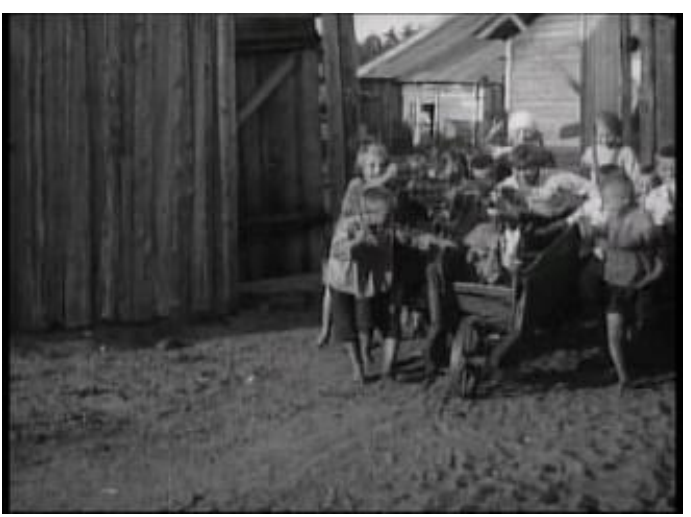

Figura 20 
"Massacre dos operários"

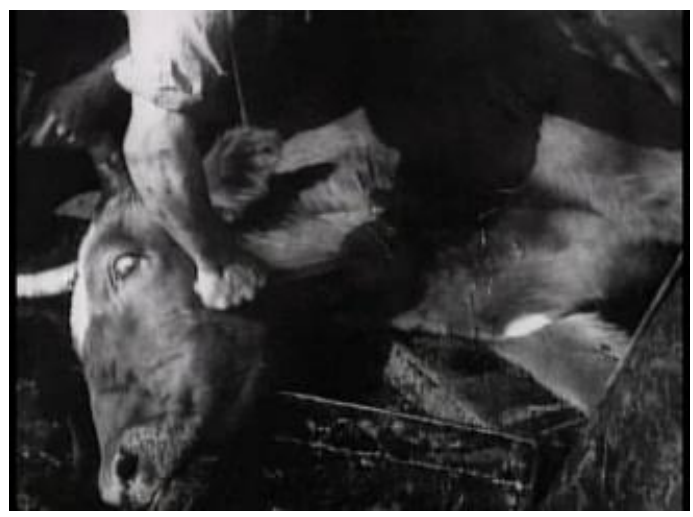

Figura 21

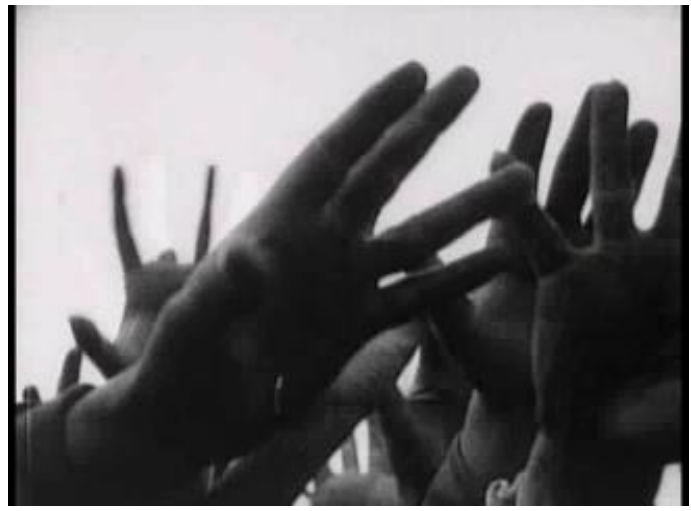

Figura 23

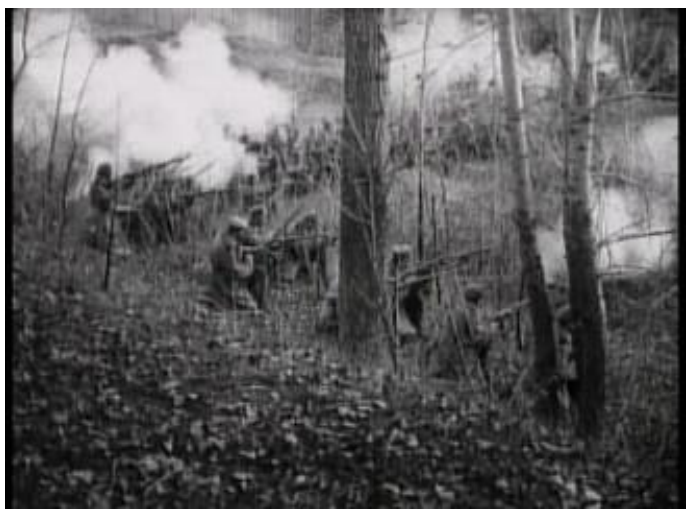

Figura 22

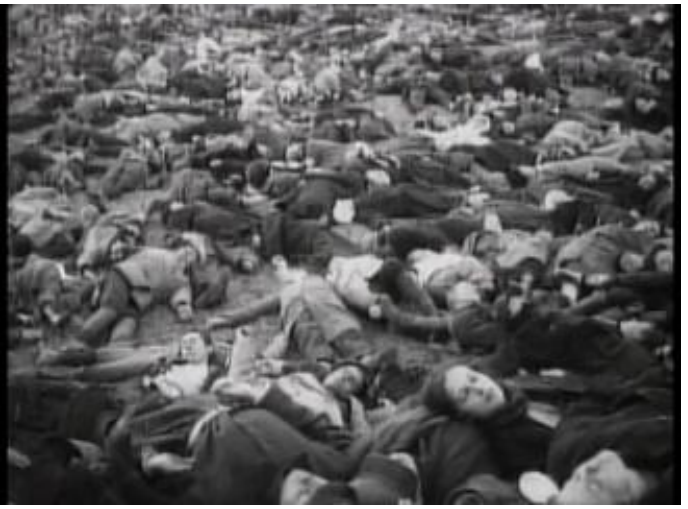

Figura 24

Apropriadas como metáforas e contrapostas a segmentos narrativos, as imagens de animais funcionam como pontuações figurativas utilizadas para reforçar o efeito de agitação da película. O cineasta utiliza também os letreiros para essa finalidade, fazendo interferências no filme que extrapolam a dimensão da narrativa. "Preparação" prenuncia as atividades clandestinas dos trabalhadores e o trabalho de espionagem da polícia. "Pega!" aparece várias vezes nas cenas onde operários grevistas são capturados. Outros letreiros indicam uma interferência da narração: "Ladrão!" aparece três vezes na seqüência que precede o suicídio do trabalhador acusado de roubar um micrômetro. A narrativa do filme deixa claro o fato de que a acusação é injusta. 
O letreiro intercalado dialogicamente à ação provoca diretamente o espectador suscitando a sua reação, reforçando o processo de identificação com a personagem vitimada, potencializando assim o caráter emocional da seqüência. ${ }^{183}$

"Acusação e suicídio de Yakov Strongen"

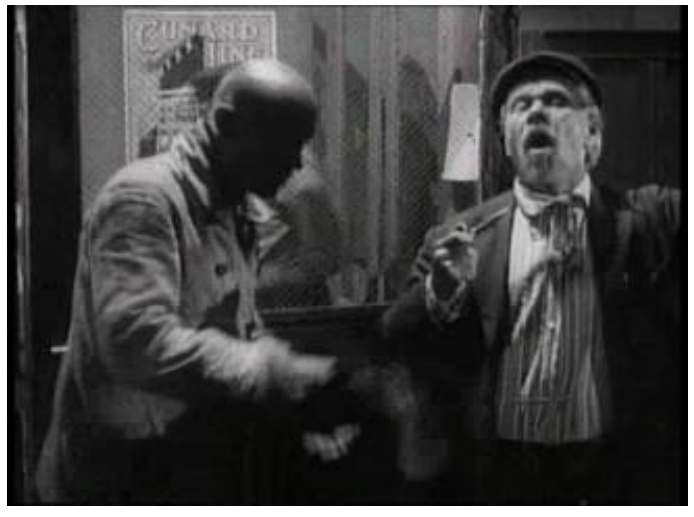

Figura 25

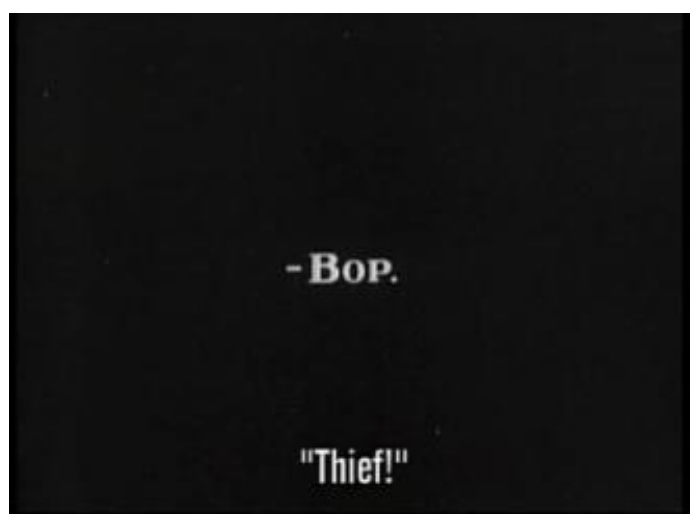

Figura 27

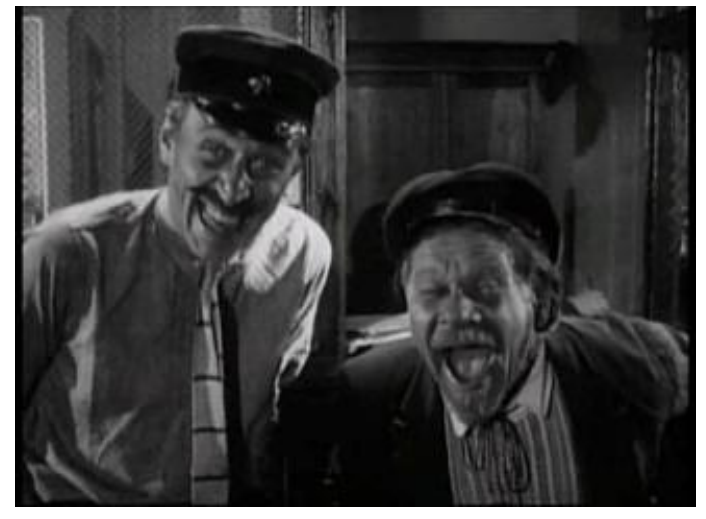

Figura 26

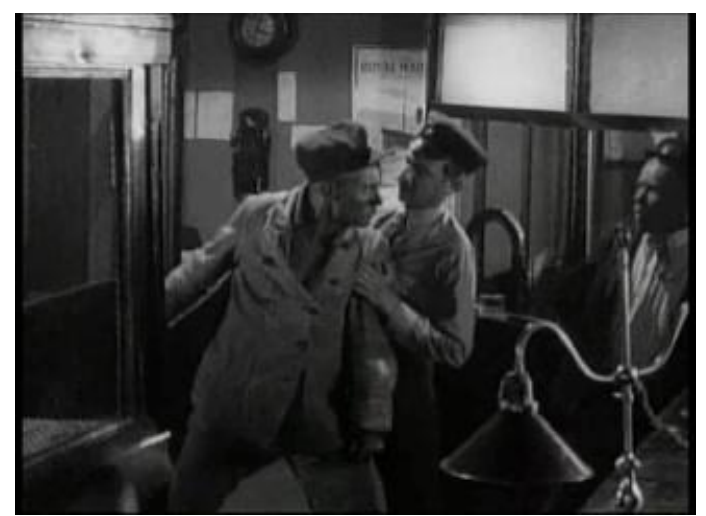

Figura 28

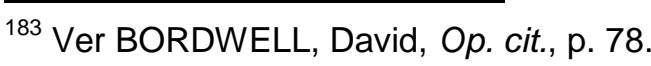




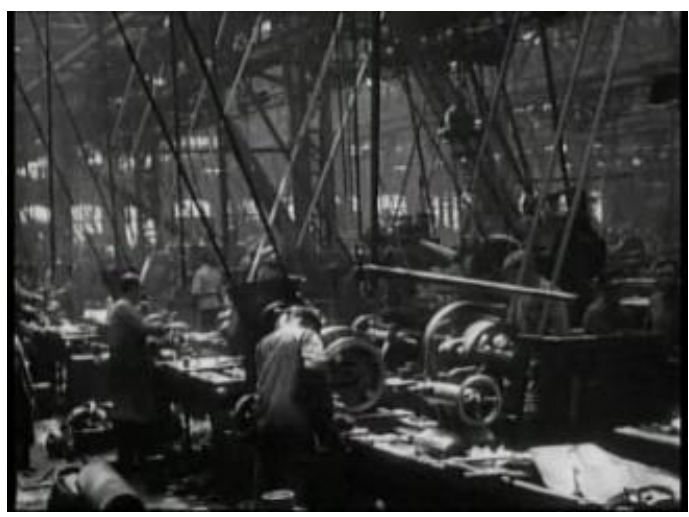

Figura 29

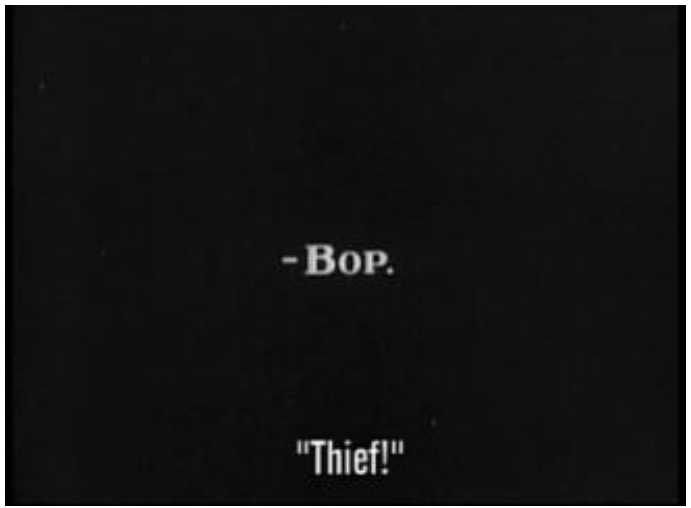

Figura 31

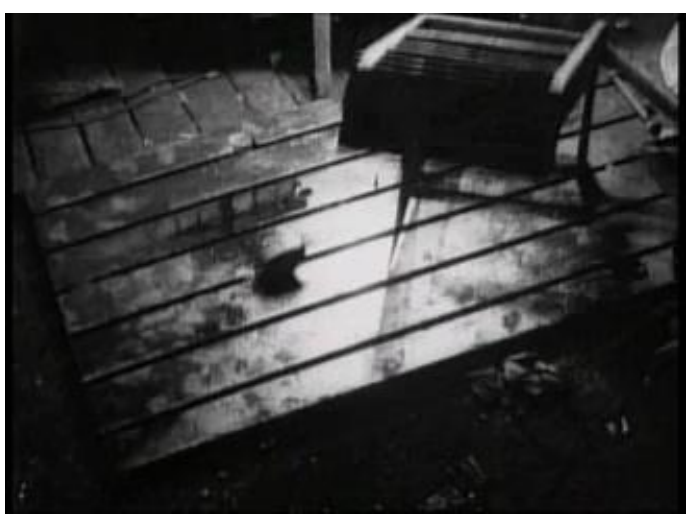

Figura 33

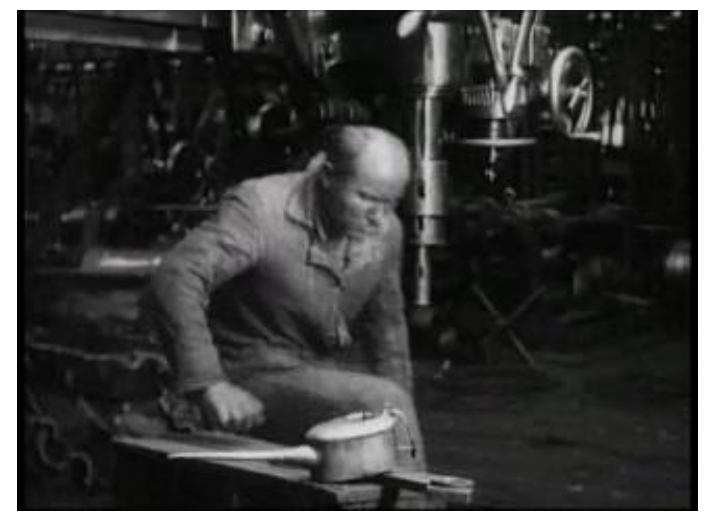

Figura 30

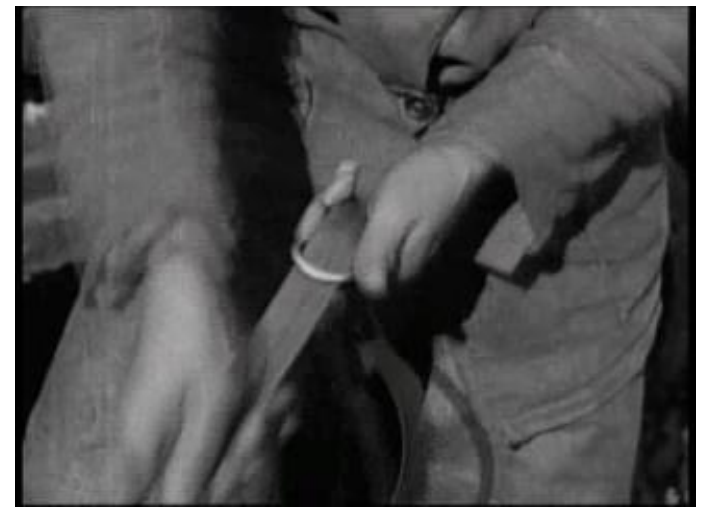

Figura 32

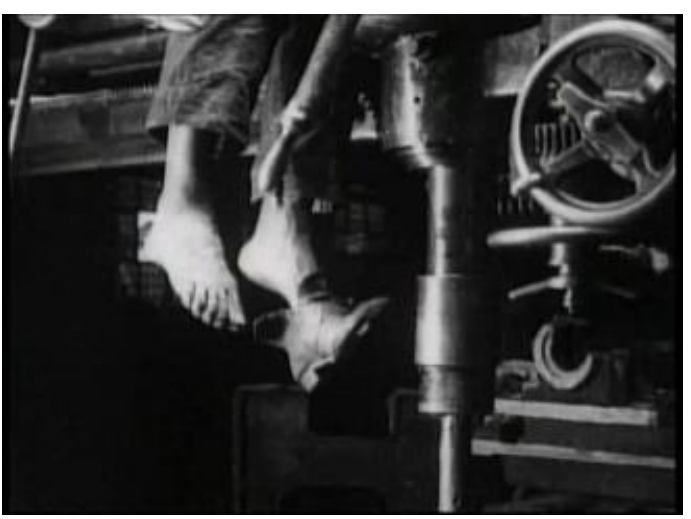

Figura 34 


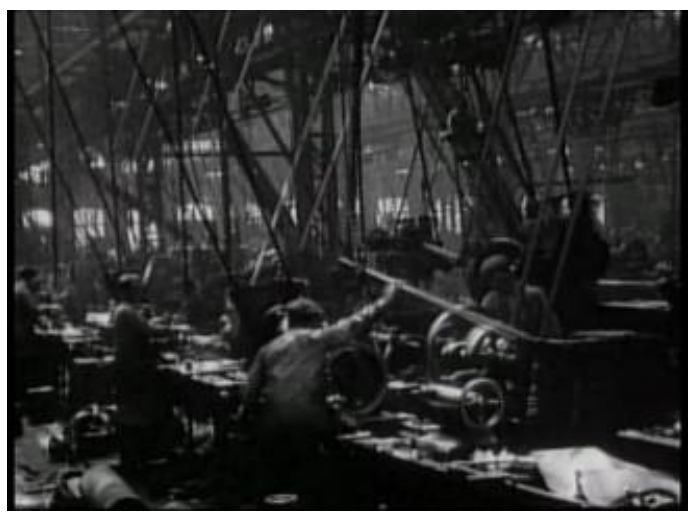

Figura 35

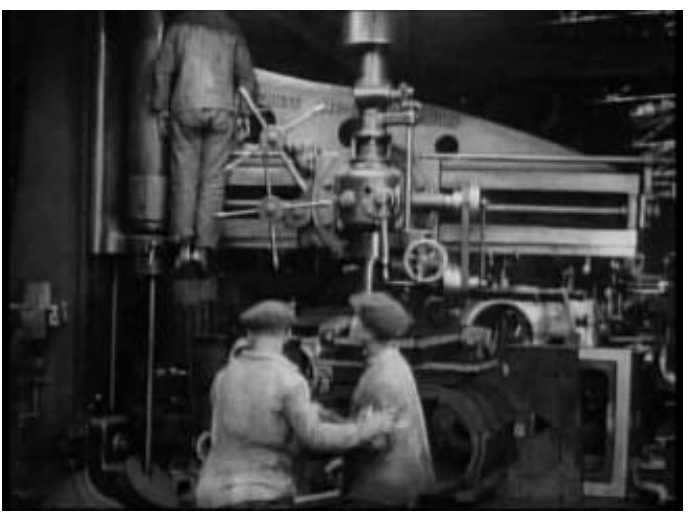

Figura 36

Ao trabalhar as cenas de ação na trama narrativa, Eisenstein efetua uma ampla exploração das possibilidades metafóricas do cinema, mediante o uso da montagem paralela. A seqüência na qual o capataz é golpeado por uma roda suspensa, na primeira parte do filme (fig. 41 a 46), amplia a "expansão do movimento" proposta por Kuleshov, baseada no estilo de edição americano. ${ }^{184}$ Em outras cenas, a mesma estratégia é utilizada. Quando um delator esforçase para colocar suas calças, a montagem rompe a ação em seis planos, com superposições e elipses. Em outro momento, quando a narração mostra os grevistas tentando atravessar um dos acessos da fábrica, o cineasta alterna rapidamente vários planos, enfatizando a luta entre os funcionários que bloqueiam o portão (contrários à greve) e os trabalhadores mobilizados para a greve (fig. 47 a 53). Eisenstein freqüentemente trata suas atrações não como elementos discretos dentro do plano, mas como estímulos cinéticos que se conectam com o fluxo da montagem e com a geometria dos planos, criando, dessa forma, um efeito de estranhamento que não desconecta a ação do tempo diegético.

\footnotetext{
${ }^{184}$ Sobre este ponto, ver: BORDWELL, David, The Cinema of Eisenstein, Cambridge, MA, Harvard University Press, 1996.Bordwell, p. 81.
} 
"Inspetor golpeado por roda suspensa"

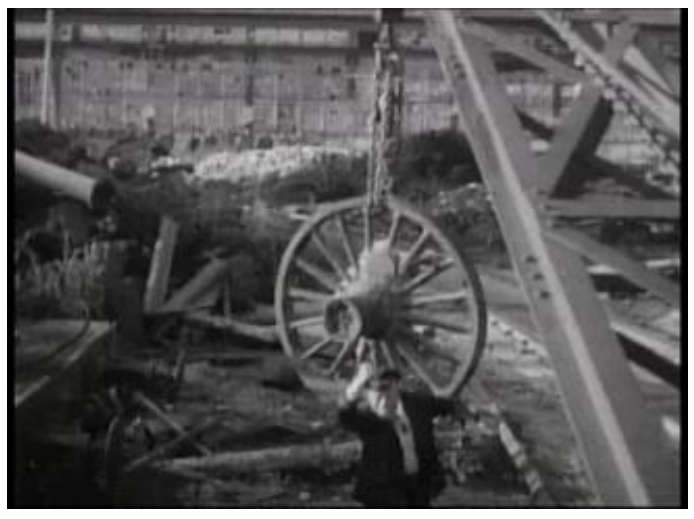

Figura 41

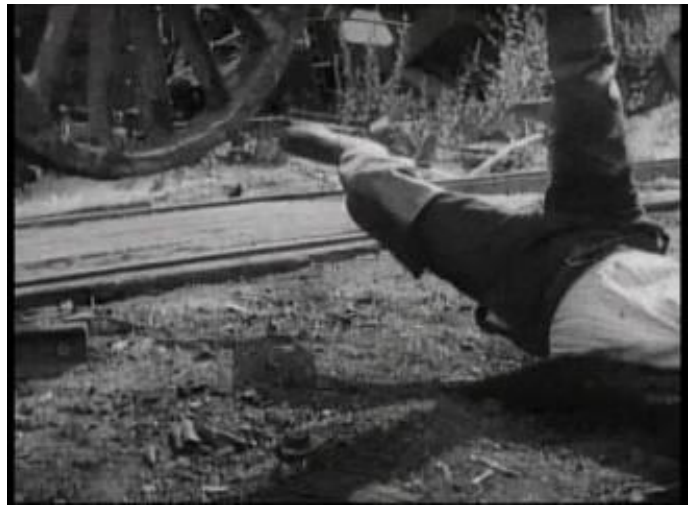

Figura 43

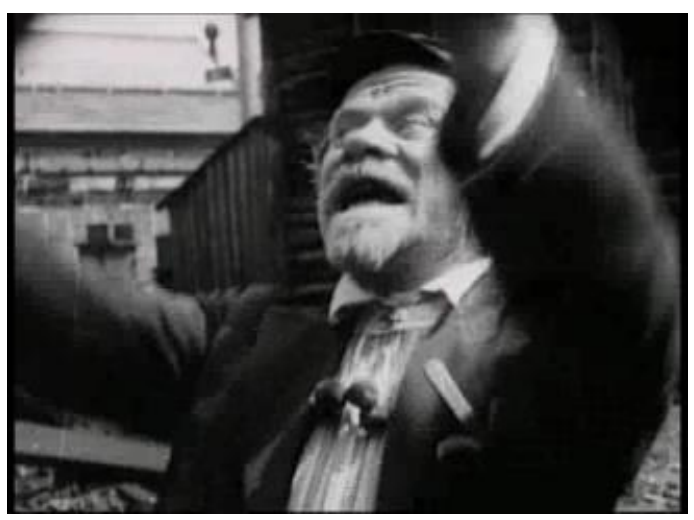

Figura 45

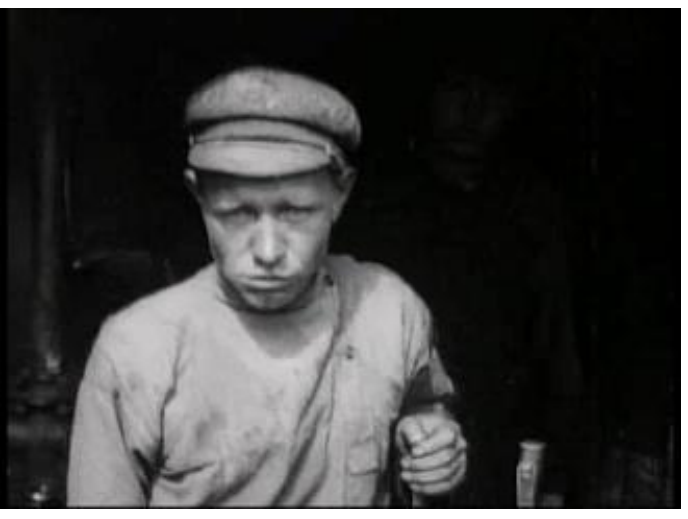

Figura 42

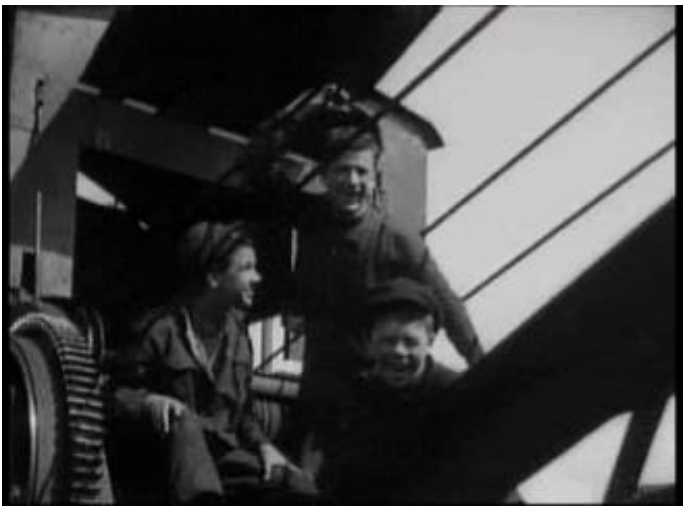

Figura 44

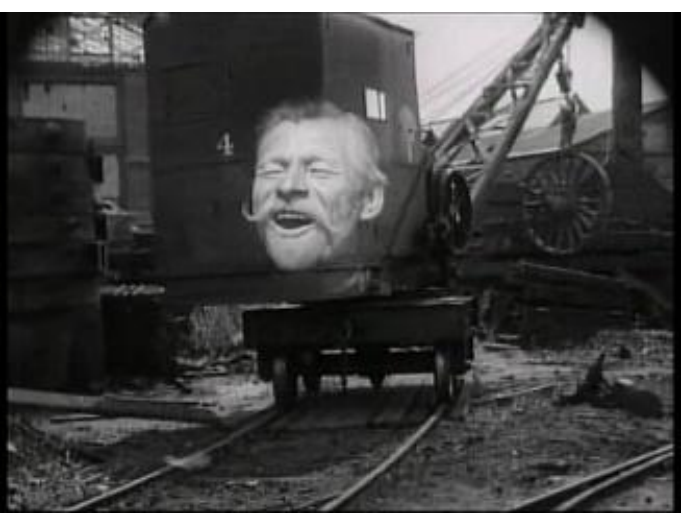

Figura 46 


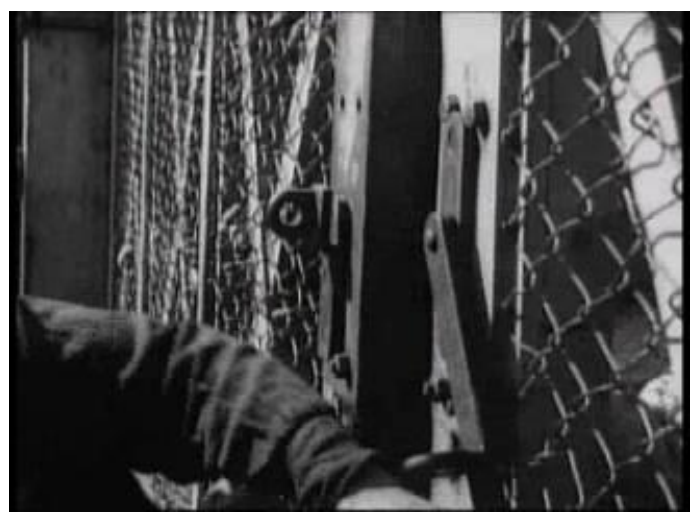

Figura 47

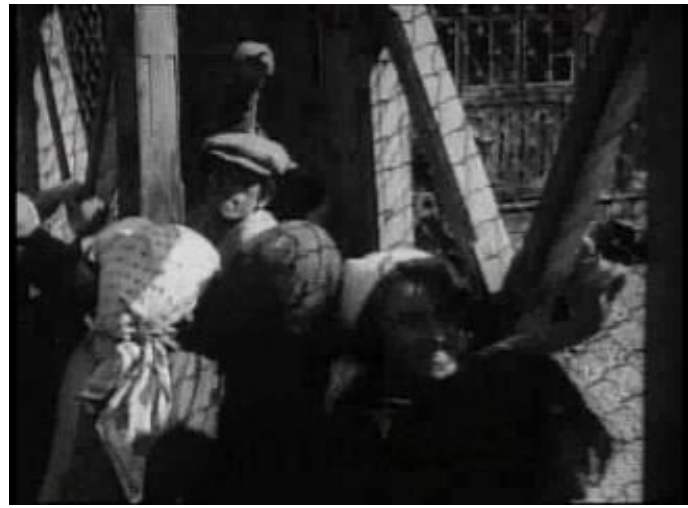

Figura 49

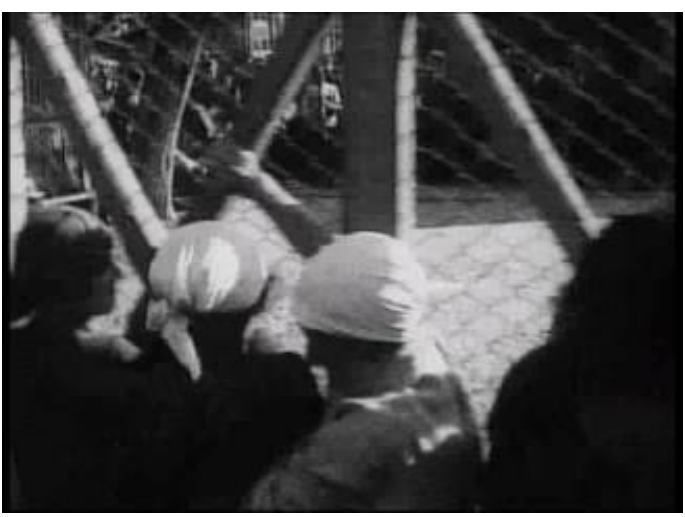

Figura 51

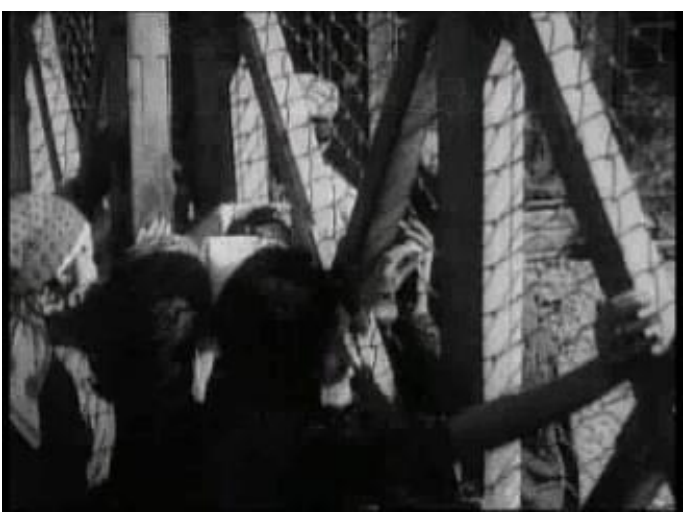

Figura 48

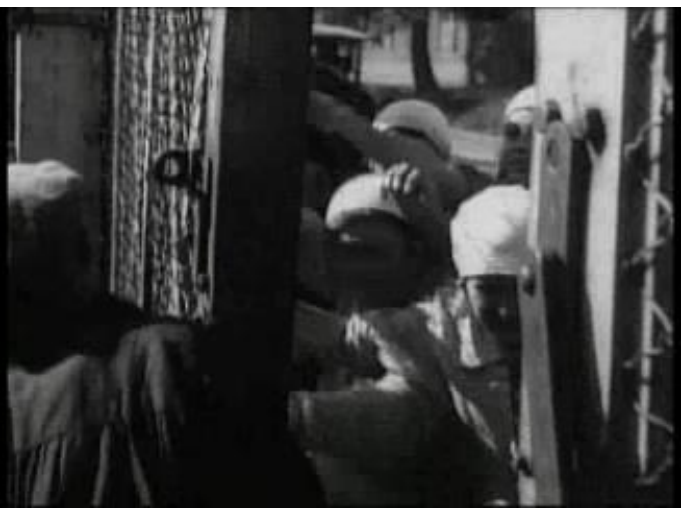

Figura 50

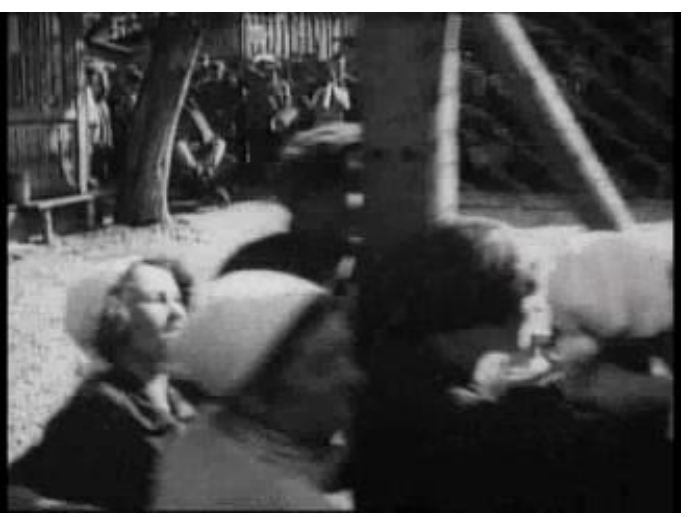

Figura 52

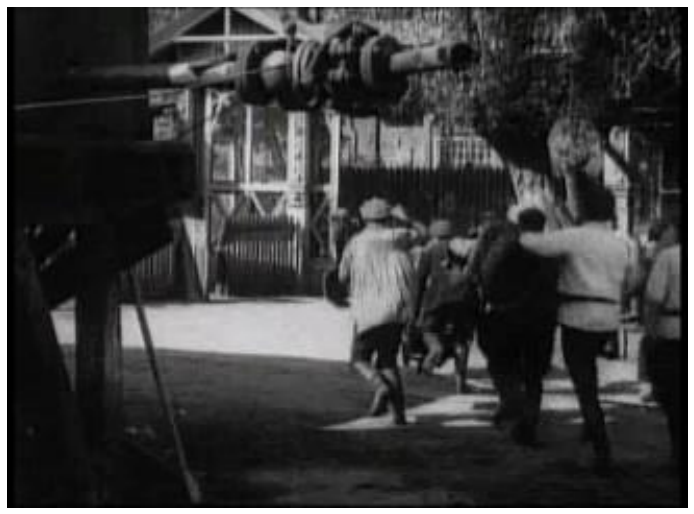

Figura 53 


\section{II: Estranhamento: a arte cinematográfica como deslocamento entre a imagem e o objeto filmado}

Pode-se dizer que todas essas estratégias "estilísticas" - metáforas, comparações, etc. - estabelecem uma relação com posições de Chklóvskii sobre o cinema, a partir de sua teoria do остранение (estranhamento). Para o escritor moscovita, "apenas na medida em que se obtenha uma diferença uma distância, um deslocamento - entre imagem e objeto filmado, entre signo e objeto, o cinema existirá como arte". ${ }^{185}$ Nesse sentido, o caráter artístico de Stachka se constrói na medida em que ele (o filme) estimula o espectador à intelecção por meio do choque e da fragmentação das imagens.

Chklóvskii considera que a poesia, assim como o cinema, é uma maneira particular de pensamento (um pensamento que opera por meio de imagens). Em seu ensaio $A$ arte como procedimento ${ }^{186}$, texto escrito em $1916 \mathrm{e}$ posteriormente republicado na coleção de ensaios sobre o cinema Poetika Kino (Поетика Кино) em 1927, o teórico moscovita formula pela primeira vez o conceito de остранение (estranhamento), a partir de uma análise da obra de Tolstoi. Neste texto Chklóvskii combate a posição teórica de Aleksandr Potebnia (1835-1891) sobre as especificidades das imagens que a linguagem poética pode evocar e sobre a função da arte. As imagens são, na perspectiva do Potebnia, objetos que nos ajudam a compreender a significação da linguagem poética, na medida em que elas se relacionam diretamente com a vivência cotidiana e com o momento histórico presente.

\footnotetext{
${ }^{185}$ ALBERA, François, op. cit., p. 242

${ }^{186}$ CHKLÓVSKII, Victor, "A arte como procedimento", in TEORIA DA LITERATURA: formalistas russos, Porto Alegre, Ed. Globo, 1970.
} 
Para Chklóvskii, a imagem poética se diferencia das imagens prosaicas - os esquematismos que criamos para lidar de modo automático com a vida cotidiana - na medida em que a imagem poética é um dos recursos de que a arte se utiliza para obter formas que possam despertar uma impressão sensorial intensa. As imagens, inseridas dentro da forma artística, operam de maneira semelhante a outros procedimentos da língua poética, tais como a comparação, a repetição, a hipérbole, a analogia, etc. Comparar uma melancia com uma bola é uma forma de pensamento que utiliza imagens, todavia, é um pensamento que nada tem a ver com a poesia ou com as artes visuais.

A teoria do estranhamento de Chklóvskii configura-se como um dispositivo conceitual que contribui para a compreensão da mediação entre a arte e a vida. ${ }^{187}$ Quando o artista cria (recorta, molda, monta, etc.) imagens que surpreendem seu público (ou seus espectadores), ele não desloca simplesmente as imagens da vida cotidiana para uma estrutura formal artística, mas, utilizando o procedimento do "estranhamento", cria uma nova experiência da realidade, combatendo os automatismos que o mundo do trabalho (junto com toda a exploração que lhe é própria) e as necessidades práticas da experiência cotidiana (tais como: viver sob o signo de uma agenda de reuniões) inserem na vida mental subjetiva. O procedimento de "estranhamento" (остранение) é o que faz a arte ser artística e, ao mesmo tempo, vivifica as experiências vividas, por meio da fruição das imagens poéticas.

E eis que para devolver a sensação de vida, para sentir os objetos, para provar que pedra é pedra, existe o que se chama arte. O objetivo da arte é dar a

\footnotetext{
${ }^{187}$ Sobre este ponto, ver: BOYM, Svetlana, "Estrangement as a Lifestyle: Chklóvskii and Brodsky", in Poetics Today, Vol. 17, No. 4, Duke University Press, Winter 1996, pp. 511-530.
} 
sensação do objeto como visão e não como reconhecimento; o procedimento da arte é o procedimento da singularização (estranhamento) dos objetos e o procedimento que consiste em obscurecer a forma, aumentar a dificuldade e a duração da percepção. $O$ ato de percepção em arte é um fim em si mesmo e deve ser prolongado. ${ }^{188}$

Deste modo, o objetivo da imagem poética é criar uma percepção nova e crítica dos objetos, por meio do sentimento de estranhamento. Trata-se de estabelecer uma nova visão de mundo e não o reconhecimento do mundo dado. Para Chklóvskii (e também para Eisenstein), se a imagem artística se refere aos objetos e materiais da vida cotidiana, ela o faz puramente por questões circunstanciais ou funcionais, implicadas na prática estética. A arte cria imagens para libertar o signos, o objeto e a percepção sensível do automatismo, historicamente estabelecido na vida cotidiana. "[...] Sua visão representa o objetivo do criador e ela é construída artificialmente de maneira que a percepção se detenha nela e chegue ao máximo de sua força e duração". ${ }^{189}$ Nesse sentido, os objetos e formas das imagens evocadas pelo cinema e pela poesia não devem ser percebidos singularmente, mas por meio das relações que estabelecem entre si na construção poética, fílmica, etc.

${ }_{188}$ CHKLÓVSKII, Victor, Op. Cit., p. 45. Itálicos meus.
${ }^{189}$ Idem, p. 54 . 


\section{III: A estilização como ferramenta eficaz para introduzir o espectador na ação e na trama}

Máscaras de Gás (montada em 1924), a última "montagem de atrações" que Eisenstein encenou como diretor de teatro da Proletarskaya Kultura, e seu primeiro longa-metragem, A Greve (filmado em 1924), foram produzidos em fábricas. Ao efetuar sua passagem "do teatro ao cinema" Eisenstein transpõe vários elementos construtivos de seu trabalho anterior na Proletkult para 0 âmbito do cinema Assim a encenação teatral excêntrica, o uso sistemático de tomadas externas em cenários reais (fábricas, prédios inacabados, depósito de materiais metalúrgicos) e as várias referências ao trabalho com máquinas, derivam de práticas teatrais desenvolvidas pelo diretor, e se constituem na matéria-prima de diversas "atrações" que compõem os planos de Stachka. ${ }^{190}$

A atração teatral (elemento esteticamente agressivo do espetáculo) dá lugar às relações entre os fotogramas no encadeamento da montagem e no desenvolvimento da narrativa. A imagem cinematográfica, ao contrário da encenação teatral, não apresenta um fato em sua totalidade, mas representações e recortes destes fatos, Eisenstein observa que a aplicação da montagem de atrações torna-se mais eficiente no cinema do que no teatro. Em seu método construtivo, para cada fenômeno que o cinema apresenta, faz-se necessária uma comparação, um recorte, uma apresentação sob ângulos fotográficos diferentes. Um fragmento da narrativa, que pode ser apresentado facilmente no teatro pela interpretação do ator, exige no cinema uma sucessão

\footnotetext{
${ }^{190}$ EISENSTEIN, Sergei M., "The Montage of Film Attractions", in S. M. Eizenshtein Writings, 1922-34, TAYLOR, Richard (Ed. e trad.), London, BFI Publishing, 1987, p. 39.
} 
variada de planos. Se um efeito (afecção) no teatro é obtido principalmente através da percepção "física" de uma ação encenada (por exemplo, o horror que a cena de um assassinato pode causar), no cinema, este efeito necessitaria de uma justaposição e de uma acumulação de fatos na psique do público, a partir dos elementos que compõem o evento apresentado (neste caso, todos os momentos que engendram um homicídio: a perseguição, 0 assassinato, a ocultação do cadáver, etc.).

Sendo assim, as imagens de Stachka não devem ser consideradas apenas como reflexos passivos da realidade, fragmentos arrancados dos fatos materiais e históricos (grosso modo, como ocorre no processo de construção cinematográfica de Vertov). A imagem, nessa primeira experiência de Eisenstein com o formato longa-metragem (o então diretor de teatro já havia trabalhado em um curta-metragem que estabelecia fortes relações com a atração teatral), já adquire estatuto de signo. Pensada como sistema, a montagem de atrações no cinema funciona de modo análogo a uma língua que reestrutura e reorganiza as palavras, fornecendo novos significados para os objetos e fatos históricos com os quais pretende trabalhar.

No campo das teorias do cinema, a primeira formulação desse tipo foi elaborada por pelo teórico e crítico literário luri Tynianov (1894-1943), no ensaio O cinema - a palavra - a música (КИНО - СЛОВО - МУЗЫКА ${ }^{191}$, publicado em janeiro de 1924. Neste texto, o ele caracteriza o cinema como uma forma artística "abstrata", que tem como fundamento a decomposição da

\footnotetext{
191 TYNIANOV, IUri, ПОЭТИКА. ИСТОРИЯ ЛИТЕРАТУРЫ. КИНО, Москва, Издательсто “Наука", 1977, pp. 249-251. Versão digital em formato hipertexto obtida em http://az.lib.ru/t/tynjanow_j_n/.
} 
palavra (em seus elementos constituintes: sonoridade, significação, etc.), ${ }^{192}$ do corpo do ator e do plano fotográfico. O filme, nessa perspectiva, é um meio no qual uma variedade sem precedentes de objetos e tramas podem transitar. Para Tynianov, o cinema é o lugar de um novo gênero literário épico: o кинороман (kinoroman: o cine-drama ou cine-romance). É muito provável que Eisenstein tenha discutido ou tido acesso a essa teorização, na medida em que seus textos e sua produção artística no período de 1924-25 dialogam com diversas considerações dos formalistas russos do grupo OPOJAZ ${ }^{193}$, principalmente Tynianov (sobre a fragmentação e o caráter associativo da montagem) e Chklóvskii (sobre a noção de "estranhamento").

Ao discorrer sobre "os fundamentos do cinema", Tynianov estabelece a fragmentação como uma importante característica da técnica cinematográfica $^{194}$. Para o teórico, a construção do plano cinematográfico deve ser permeada pela unidade dos ângulos de câmera e pela luz a ser delimitada pelo diretor. Cada plano, por mais breve que seja, equivale a uma centena de angulações e iluminações heterogêneas - possibilidades que serão utilizadas

\footnotetext{
192 Em O cinema - a palavra - a música, Tynianov caracteriza o cinema como "a arte das palavras abstratas" (Кино - искусство абстрактного слова). De acordo com a perspectiva do teórico, o cinema mudo lida com diversos elementos que constituem o universo dos signos da língua fonética. A mímica empregada pela atuação, o movimento labial dos corpos dos atores e a música instrumental incorporada à ação fílmica constroem os signos que remetem às palavras empregadas pela narrativa do cinema e aos seus respectivos sons. Para Tynianov, o cinema decompõe os signos lingüísticos por meio de seus recursos expressivos. Idem, $p$. 250.

${ }^{293}$ O OPOJAZ (Obscestvo izucenija Poeticeskogo Jazyka - Sociedade para o Estudo da Linguaguem Poética, 1916-1930) tinha como objetivo principal o desenvolvimento do método formal de análise literária. Fundada por estudiosos da linguagem, segundo a escola de Baudoin de Courtenay, como E. D. Polivánov (1891-1938) e teóricos da literatura como B. Eikhenbaum (1886-1959), V. Chklóvskii (1893-1984) e O. Brik (1888-1971), seguidos, mais tarde, por I. Tiniánov (1894-1943), V. Vinográdov (1895-1969) e V. Jirmúnski (1881-1971). O OPOIAZ propunha uma redefinição do verdadeiro objeto dos estudos literários, recusando categoricamente as interpretações extraliterárias do texto, rejeitando a filosofia, a sociologia, a psicologia e a biografia como ponto de partida para a abordagem literária.

${ }_{194}$ TYNIANOV, Yuri, Los fundamentos del cine", in ALBĖRA, François (Org.), Los Formalistas Russos y El Cine, Barcelona, Paidós Comunicación, 1998, pp. 76-100.
} 
ou descartadas no processo de decupagem. Esses "vários olhares" diferentes remetem às diversas correlações (semânticas) possíveis entre as personagens e os objetos captados pela objetiva, que serão escolhidas pelo trabalho de direção. No caso do teatro, cinco cenários (imagens estáticas) diferentes correspondem a cinco lugares diferentes. No cinema, por sua vez, o plano (o lugar onde se desenrola a ação) é o espaço no qual os objetos da realidade (os objetos filmados) adquirem um novo estatuto de significação, na medida em que eles (assim como os planos) são transfigurados, transpassados e recortados (etc.) pela montagem e pelas escolhas da direção.

Portanto, para Tynianov (e também para Eisenstein), o cinema, apresenta homens e objetos "novos". Ainda que a arte cinematográfica lide com a materialidade do mundo, a estilização e o processo de construção do plano e da seqüência tendem (se usados de maneira adequada pelo diretor) a reconfigurar a significação desses objetos mediante um princípio construtivo. Uma obra cinematográfica bem executada é, desse ponto de vista, aquela que utiliza a estilização como ferramenta eficaz para introduzir o espectador na ação e na trama, implicando estratégias que desloquem o conteúdo semântico das situações e dos objetos da vida cotidiana, apresentando novos pontos de vista. Nessa perspectiva, o trabalho de manipulação das imagens, o ofício do diretor-montador, não pode se render ao fetichismo da "imagem material crua", na medida em que a manipulação dos fragmentos da realidade, por si só, não é suficiete para extrair o sentido das imagens captadas pela objetiva. Arte é criação de sentido, uma forma de reinventar visualmente a percepção da realidade material. O objeto "visível" é, por fim, substituído pelo objeto 
"artístico", uma imagem que dialoga com sua correspondente material e, ao mesmo tempo, oferece uma nova percepção de mundo.

\section{IV: A Greve: uma montagem de "coisas reais" (vechtch)}

A sociologia da arte de Boris Arvatov (1896-1940) foi também outra influência que o cineasta trouxe de sua experiência no teatro do Proletkul't para o cinema. No manifesto Montagem de Atrações (1923), Eisenstein afirma que a formulação da proposta teórica de seu teatro de atrações adveio da colaboração de ambos. Em Stachka é possível identificar alusões à teoria do "objeto socialista" do sociólogo moscovita. A caracterização das situações cotidianas urbanas que permeiam a trama, a apresentação esquemática e didática do processo grevista e as relações estabelecidas entre os trabalhadores e seus objetos (ferramentas de trabalho, maquinário pesado, imprensa, etc.), em certa medida, remetem a aspectos específicos da proposta de Arvatov para a cultura proletária soviética.

A montagem de atrações, princípio construtivo de Stachka, é uma montagem de "coisas 'reais"”. ${ }^{195}$ Nesse sentido, os objetos tem uma posição de destaque, na medida em que funcionam como fator de proximidade entre a interpretação histórica apresentada pela obra e a percepção cotidiana do espectador. Segundo a perspectiva do cineasta, ao lidar com os objetos da vida cotidiana,

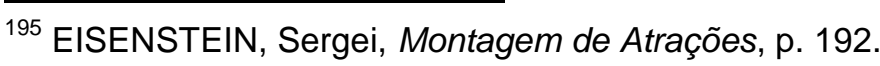


"a filmagem pela composição, a acentuação do que é necessário ou aleatório [...] à maneira do Kinoglaz, não é suficiente. Do ponto de vista da expressividade tendenciosa, cada objeto é uma composição de esquemas diferentes, que desperta campos associativos diferentes [...].

$[\ldots]$

Os meios tradicionais - composição, luz, filmagem - são insuficientes. Eles concernem apenas à expressividade do byt. Sozinho, o objeto não é a unidade de atração. ${ }^{196}$

Nas construções fílmicas de $A$ Greve, o cineasta visa, por meio das atrações (fragmentos fílmicos), levar o espectador a refletir criticamente sobre o conteúdo da cena e, por conseguinte, assimilar a mensagem política imbuída na narrativa. E não somente na narrativa. Todos os recursos plásticos dos planos são organizados para reforçar a significação das cenas. Para Eisenstein, "os objetos são um complexo de esquemas associativos possíveis", ${ }^{197}$ devem ser trabalhados a fim de que possam contribuir para propor novas formas de percepção ao proletariado.

Em seu ensaio Vida Cotidiana e a Cultura do Objeto ${ }^{198}$, escrito em 1925, Arvatov muda o foco de seus esforços teóricos sobre a arte proletária para dois temas que até então não tinha trabalhado sistematicamente em sua obra: o consumo e a vida cotidiana. Neste texto, Arvatov dirige o seu esforço teórico para pensar como a cultura proletária poderia transfigurar a "mercadoria passiva capitalista" em um "objeto socialista ativo". ${ }^{199}$ Ligado ao trabalhador

\footnotetext{
${ }^{196}$ EISENSTEIN, Sergei, Esboço de um artigo ou de uma resposta à ARKK, datado de 1925. Inédito. TSGALLI, 2-763, apud ALBERA, François, Op. Cit., p. 246.

${ }^{197}$ ALBERA, François, Op. Cit., p. 246.

198 ARVATOV, Boris, "Everyday Life and the Culture of the Thing", in OCTOBER 81, Cambridge, MA, MIT Press, Summer 1997, pp. 119-128.

${ }^{199}$ Embora o foco principal de Vida Cotidiana e a Cultura do Objeto seja a discussão sobre o impacto dos objetos de consumo no âmbito da experiência cotidiana (byt) do proletariado, o texto não pode ser desvinculado das questões elencadas por Arvatov em seus trabalhos anteriores. De acordo com a historiadora Maria Zalabani, em Proletariat i levoe iskusstvo $(O$ Proletariado e a Arte de Esquerda) - artigo publicado em 1922, na revista Vestnik iskusstv, o
} 
pela experiência do dia a dia, este novo objeto seria capaz de produzir novas relações de consumo a partir de novas práticas cotidianas.

No texto, Arvatov parte do princípio de que no sistema capitalista o conceito de "vida cotidiana" (byt) ${ }^{200}$ foi formado em oposição ao conceito de trabalho, assim como o conceito de atividade consumidora se opõe ao de atividade produtiva ${ }^{201}$. Convicto de que o sujeito moderno é formado tanto pela maneira como utiliza objetos na vida cotidiana quanto pela forma que os produz, Arvatov propõe uma transformação da esfera da vida cotidiana, dominada pelo fetiche da mercadoria, através da criação de "coisas socialistas", objetos socialmente úteis, que seriam elaborados de acordo com as necessidades cotidianas do proletariado.

Nessa perspectiva, para que seja possível a construção de uma cultura proletária - uma cultura verdadeiramente organizada de forma consciente pela classe trabalhadora - se faz necessário criar estratégias capazes de combater o fetichismo da mercadoria. Esse tipo de construção social pressuporia o estabelecimento de um ponto de vista metodológico capaz de entender o

\footnotetext{
teórico considera que a consciência social presente na prática artística desenvolvida pela Proletkult e pela vanguarda construtivista não pode ser dissociada do âmbito da Revolução em todos os seus aspectos. Para Arvatov, a revolução técnica - que introduziu novas formas na vida cotidiana do trabalhador -, a revolução artística do construtivismo (a passagem da representação para a construção) e a revolução bolchevique - processo histórico introdutor de novas formas de organização social - são três forças que agem simultaneamente e se complementam. Sobre este ponto ver ARVATOV, Boris, "Proletariat i levoe iskusstvo" (Le prolétariat et l'art de gauche), Vestnik iskusstv, no. 1, 1922, p. 10. Ver também ZALAMBANI, Maria, "Boris Arvatov, Théoricien du productivisme", in Cahiers du Monde russe, Vol. 40, No. 3 , Paris, Éditions de l'EHESS, 1999, pp. 415-446.

${ }^{200}$ Vale ressaltar que termo russo byt (vida cotidiana) tem uma conotação material mais forte do que em outras línguas ocidentais, como o inglês (everyday life). Arvatov considera, ao pontuar a oposição entre vida cotidiana e trabalho produtivo, que as formas materiais do byt constituem as estruturas do bytie, a existência espiritual (sendo o termo espírito entendido como categoria filosófica, Geist). Sobre a questão este tema ver BOYM, Svetlana, Commom Places: Mythologies of Everyday Life, Cambridge, Harvard University Press, 1994.

${ }^{201}$ KIAER, Christina, "Boris Arvatov's Socialist Objects", in OCTOBER 81, Cambridge, MA, MIT Press, Summer 1997, pp. 105-118.
} 
mundo dos objetos como a base material da criação de formas culturais. Para Arvatov, se a teoria materialista prestasse mais atenção para os tipos de relações existentes entre os sujeitos e os objetos da vida cotidiana, ela poderia ser capaz de antecipar as tendências desenvolvidas pela cultura material proletária e ajudar a pensar novas formas de organização de trabalho socialmente útil.

Nesse sentido, para Arvatov, há uma diferenciação entre o "mundo dos objetos" e o "mundo das pessoas", uma vez que a burguesia, no capitalismo financeiro, raramente tem contato físico direto com a produção de valores materiais. $\mathrm{O}$ indivíduo burguês moderno se relaciona principalmente com as formas que os objetos tomam quando são maquiados pela esfera consumo em objetos-fetiche.

Eisenstein, em $A$ Greve, esclarece esses dois aspectos (mais especificamente, aos proletários soviéticos, na medida em que o filme é endereçado a eles) quando mostra a impotência do administrador da fábrica frente às despesas que se acumulam devido à interrupção da produção (o trabalho do burguês não se relaciona diretamente com produção material) (figs. 54 a 59). Em outro momento, o cineasta enfatiza o desdém com que os acionistas, donos do complexo industrial, tratam as reivindicações dos grevistas. Depois, o irônico letreiro "A administração tendo considerado as reivindicações dos trabalhadores com o maior cuidado..." (fig. 67) é relacionado com a imagem de um dos acionistas utilizando o papel que contem as reivindicações dos operários para limpar seu sapato durante o cocktail (fig. 60 e 62). Isolados e destacados em um espaço que destoa do resto do filme (figs. 
63, 64 e 65), esses capitalistas se mostram mais interessados numa "moderna" mesa de centro que se converte numa mesa para preparar drinques (fig. 66). Ainda nessa seqüência, o diretor, mediante montagem paralela, relaciona a imagem de um acionista operando um espremedor de limões (componente da mesa "funcional") (fig. 67) com a repressão da polícia a um grupo de grevistas reunidos em uma assembléia (fig. 68) - à espera de resposta às suas demandas. Dessa maneira, Eisenstein dá um destaque especial (em um dos pontos chave da narrativa) ao papel dos objetos-fetiche na esfera burguesa de consumo.

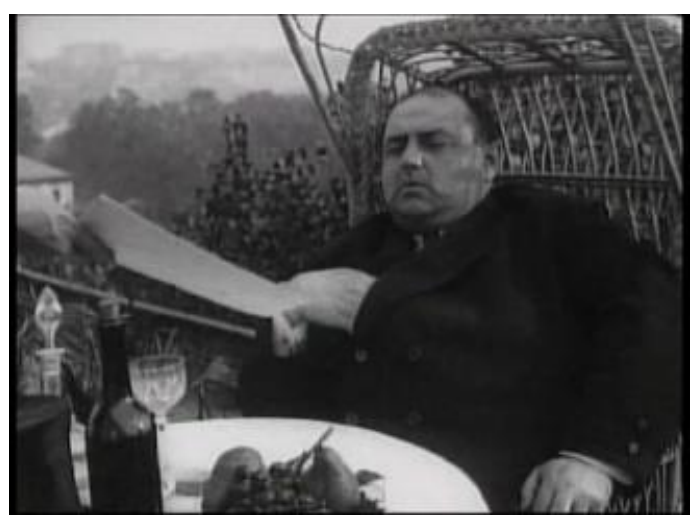

Figura 54

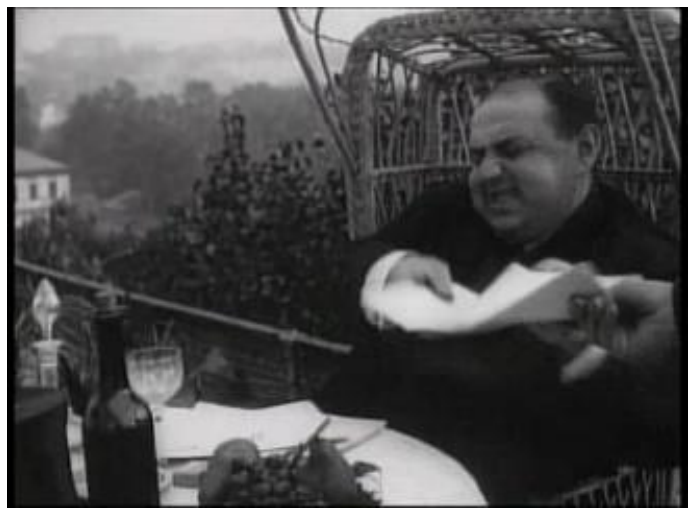

Figura 56

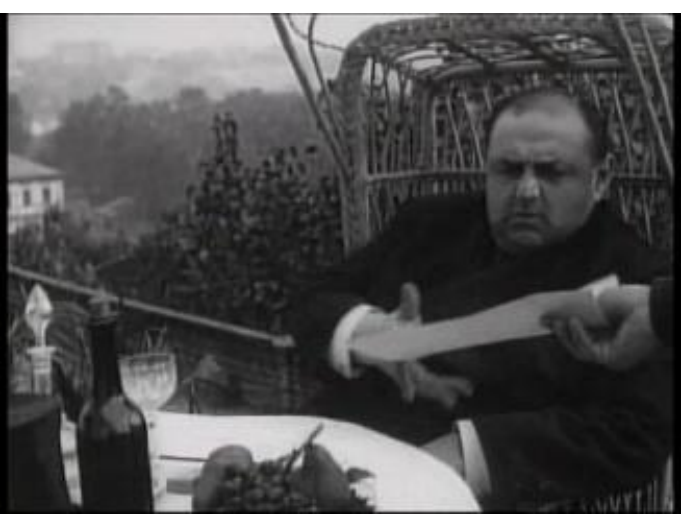

Figura 55

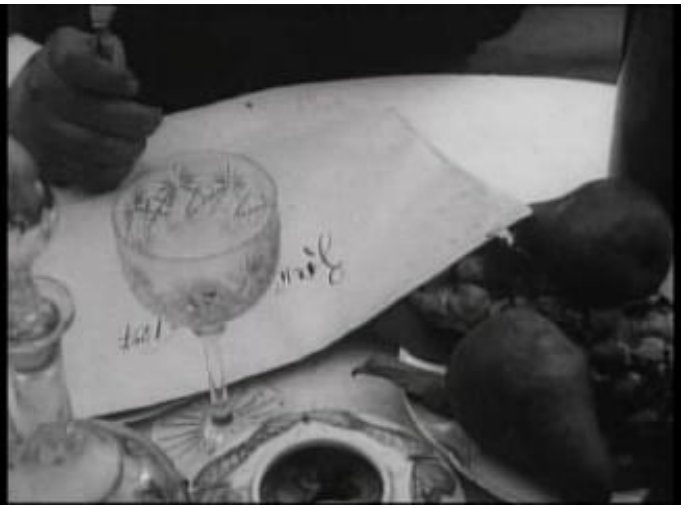

Figura 57 


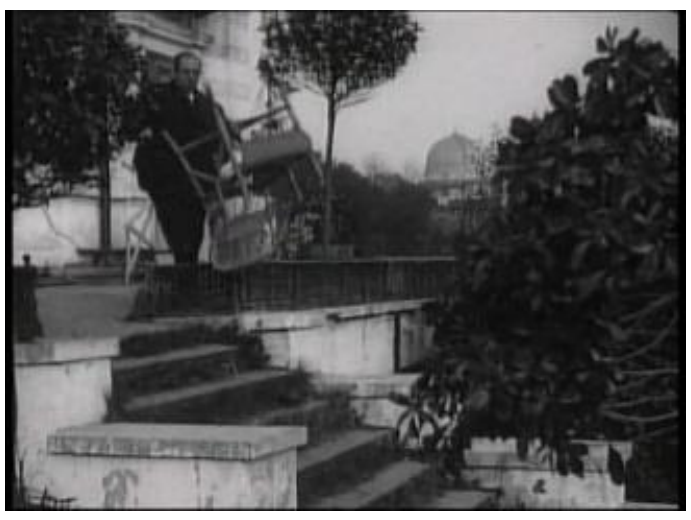

Figura 58

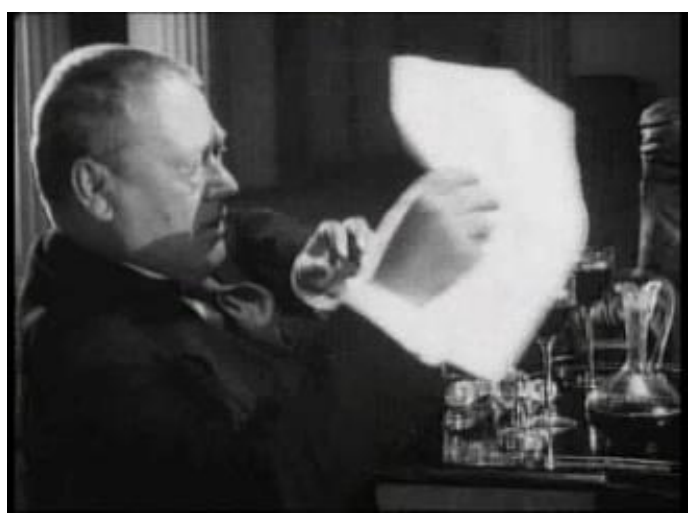

Figura 60

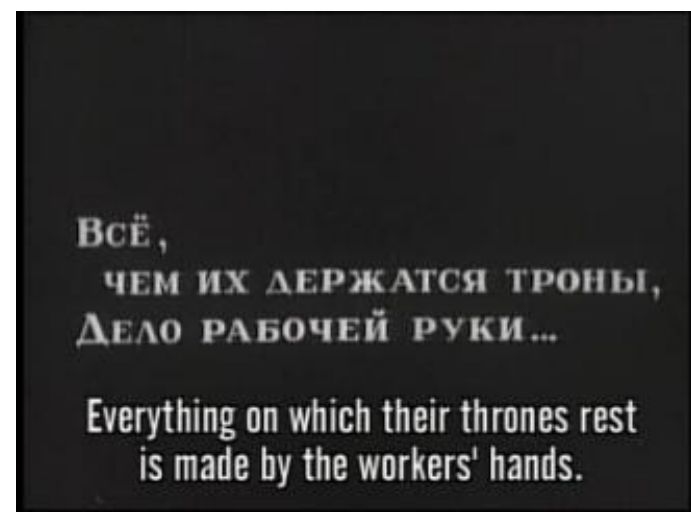

Figura 59

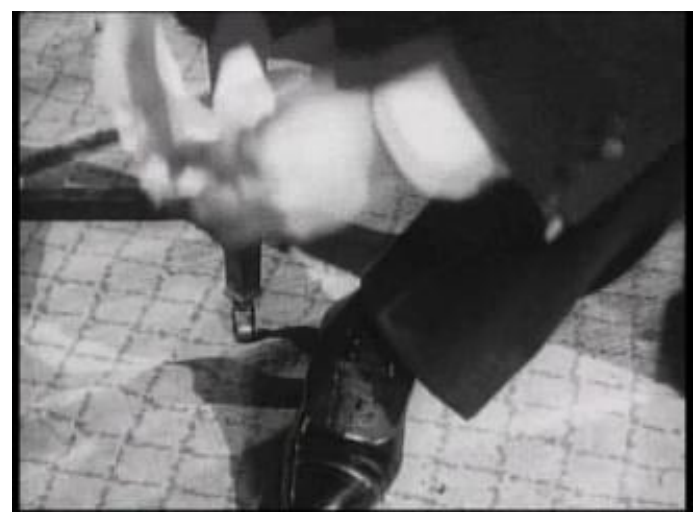

Figura 62

\section{ААМИНИСТРАщИЯ}

С ГАУБОКИМ ВНИМАНИЕМ. ОБСУАИВ ТРЕБОВАНИЯ

"The administration "haviving considered the workers' demands with the utmost care..."

Figura 61 
"Acionistas discutem as reivindicações dos grevistas"

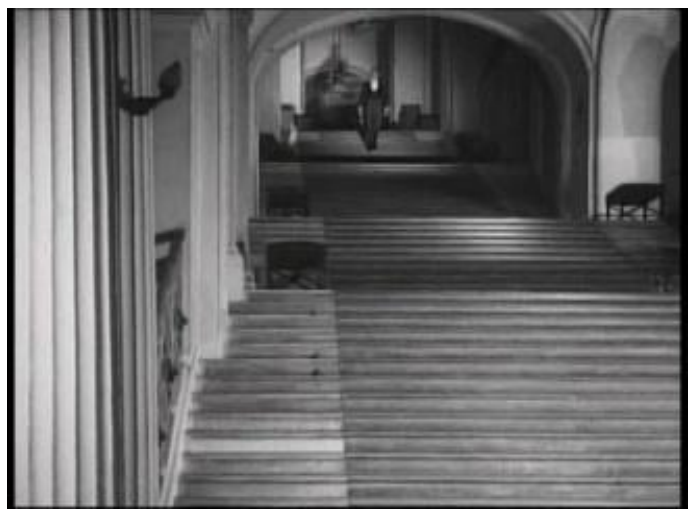

Figura 63

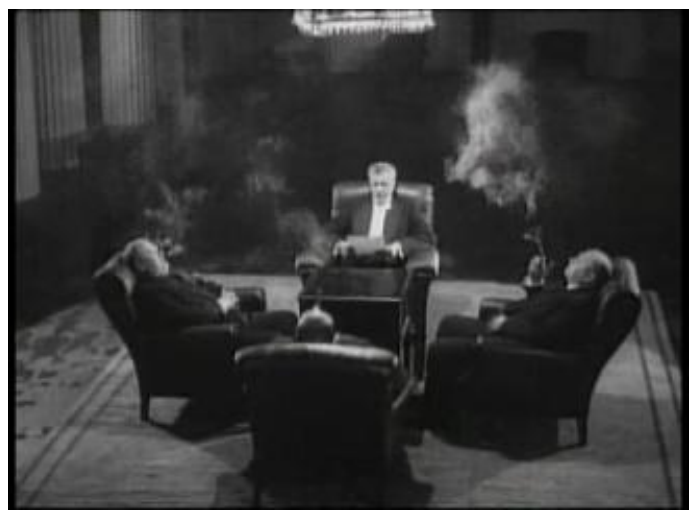

Figura 65

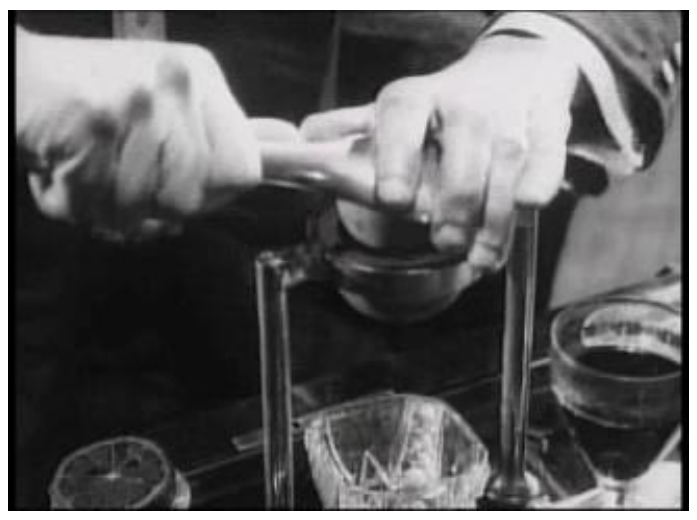

Figura 67

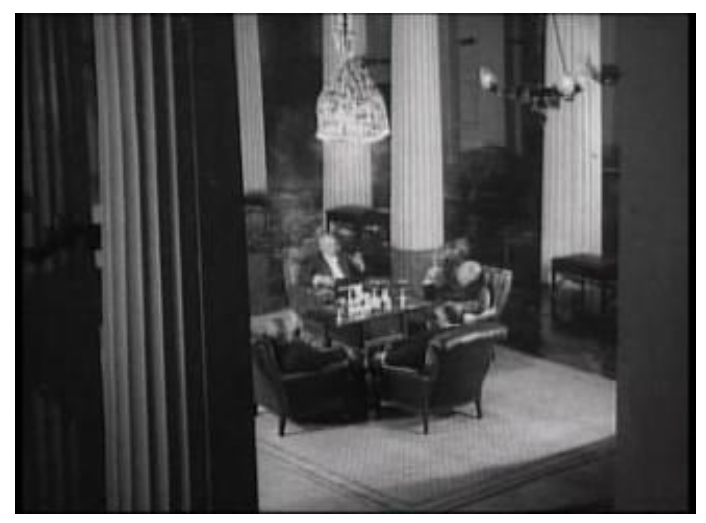

Figura 64

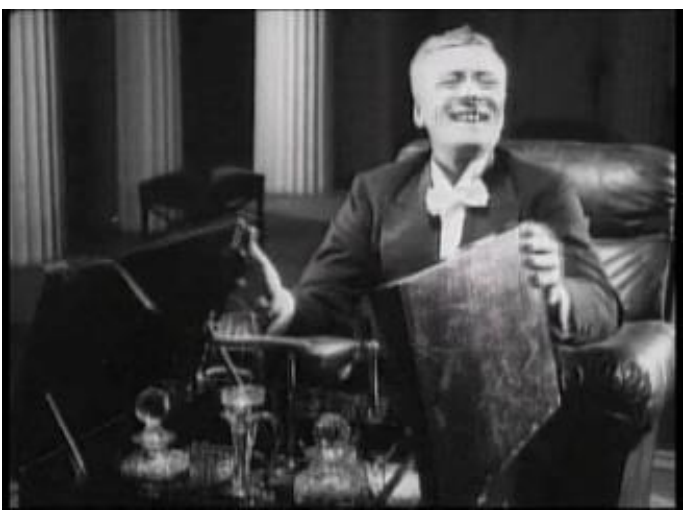

Figura 66

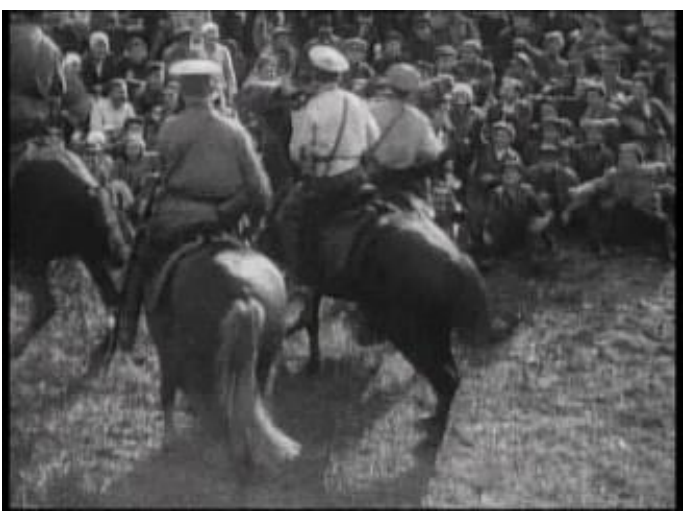

Figura 68

A transformação da vida cotidiana por meio da criação de formas orgânicas e flexíveis, objetos capazes de transformar a consciência dos indivíduos modernos, apenas torna-se possível na medida em que o processo 
de dissolução das barreiras de classe avança numa sociedade em transição para o socialismo. Nesse sentido, fomentar a constituição de novas formas para a vida cotidiana é a verdadeira tarefa dos construtores de uma possível cultura proletária. E a chave para a resolução desse problema histórico é o trabalho com as formas materiais dos objetos da vida cotidiana.

A desvinculação entre a atividade do consumo e a atividade da produção afeta radicalmente a relação do homem com os objetos, na medida em que essa relação torna-se profundamente subjetiva, permeada por abstrações, e determinada, sobretudo, pelo gosto individual. Este fato leva a dois fenômenos inter-relacionados: a estilização e a moda. Esses dois fenômenos sociais são gerados da falta de uma abordagem coletiva e produtiva do mundo dos objetos. Para Arvatov, a principal causa desses fenômenos é a tecnologia de produção de bens de consumo individual, objetos-mercadorias. Essa tecnologia, controlada geralmente pelo capital, tende a manufaturar mercadorias principalmente para consumo individual, isto é, objetos que não se interrelacionam e não constituem qualquer tipo de sistema. A produção orientada apenas para a dinâmica do mercado não leva em consideração as particularidades concretas do consumo. Ela procede apenas para gerar maisvalia.

De acordo com historiadora Christina Kiaer, a ênfase dada por Arvatov à crítica do caráter passivo das mercadorias na esfera das relações cotidianas constitui a sua contribuição à teoria de Marx sobre o fetichismo da mercadoria. ${ }^{202} \mathrm{Em}$ Marx, o valor de troca confere às mercadorias o papel de fatores ativos nas relações sociais, na medida em as mercadorias refletem as

${ }^{202}$ KIAER. Christina, Op. Cit., p. 111. 
relações sociais de produção. ${ }^{203}$ Entretanto, para Arvatov, os objetos configurados como forma mercadoria desempenham funções sociais apenas em um plano formal. Sua passividade reside na submissão de suas formas às forças espontâneas do mercado. ${ }^{204}$

Arvatov tinha convicção de que apenas a revolução socialista poderia eliminar por completo a forma mercadoria. Todavia, ele enxergava a existência de certas condições sociais, capazes de diminuir o poder do fetichismo da mercadoria, presentes na vida cotidiana da intelligentsia técnica ${ }^{205}$ das cidades industriais norte-americanas.

A nova cidade capitalista se apresenta, para o teórico, como uma série de objetos interconectados que compõem sistemas relativamente organizados. Embora mantendo as características tradicionais de uma cidade burguesa, essa nova cidade, governada pelos capitalistas financeiros, delineia um tipo diferente de vida cotidiana baseada na tecnologia e na organização sistemática do trabalho. Trata-se de uma vida cotidiana composta de grandes escritórios, lojas de departamentos, laboratórios fabris, etc. Tal forma de vida cotidiana se dá, considera Arvatov, conectada à esfera da produção material, na medida em que essa nova organização do trabalho, fundada em uma relação mais dinâmica com os objetos de trabalho, controla a atividade produtiva com mais eficiência.

\footnotetext{
${ }^{203}$ MARX, Karl, Capital: Volume 1: A Critique of Political Economy, Ben Fowkes (trad.), Erst Mandel (intro.), Penguin Classics, 1992, p. 165.

${ }^{204}$ ARVATOV, Boris, Op. Cit., 122.

205 O termo intelligentsia era utilizado pelos russos para caracterizar a elite intelectual "ocidentalizada", que se havia se formado nas melhores escolas da Europa ocidental durante 0 século XIX. No século XX, a palavra passa a se referir principalmente aos setores mais educados da burguesia russa. Ao fazer uso do termo intelligentsia técnica, Arvatov se refere à idéia de uma burguesia progressista que possui um conhecimento técnico (ciências positivas, engenharia, técnicas de administração, etc.) capaz de contribuir para a construção do socialismo soviético.
} 
De acordo com Arvatov, a base da reorganização do trabalho no capitalismo americano, no início do século XX, foi motivada pela evolução tecnológica e seus princípios de otimização e padronização, e também pela "intelligentsia técnica", que atuou como motor social para a incorporação de novas tecnologias no trabalho e também na experiência cotidiana. Aos poucos, a intelligentsia técnica foi se tornando uma organizadora de idéias, pessoas, e ferramentas, transferindo as habilidades concernentes à esfera da produção para a esfera do consumo, do cotidiano coletivo das fábricas para o cotidiano privado das casas. ${ }^{206}$

Materiais industriais como o vidro e o concreto não foram mais cobertos por artifícios decorativos e na cidade moderna eles falam por si mesmos, sem a necessidade de ornamentação. O mecanismo de um objeto, as conexões entre os seus elementos constitutivos e o seu propósito prático tornaram-se mais transparentes, na medida em que o modo de ser dos próprios objetos compele o seu usuário a utilizá-los de maneira prática. Nessa perspectiva, considera Arvatov, a mera coordenação com a forma dá lugar à coordenação com a função prática do objeto e seus métodos de construção.

Tornado funcional e ativo, o objeto se conecta ao trabalhador pela prática humana cotidiana, na resolução de problemas da dinâmica produtiva material e na otimização de processos de trabalho. A junção de mecanização mais dinamização em alguns segmentos do capitalismo moderno levou a um

\footnotetext{
${ }^{206}$ De acordo com a perspectiva de Arvatov, os objetos da esfera do consumo eram radicalmente opostos aos objetos da esfera da produção e do trabalho. Na medida em que os princípios do "fordismo" e da "taylorização" foram se consolidando no capitalismo americano nas primeiras décadas do século XX, elementos concernentes ao âmbito do trabalho útil (padronização, funcionalidade), começaram a se incorporar ao uso dos objetos de consumo e contribuíram para a transformação do cotidiano nas metrópoles americanas. ARVATOV, Boris, Op. Cit., p. 127.
} 
grau progressivo de maquinização e à transformação dos objetos cotidianos em instrumentos de trabalhos e ferramentas de organização da vida privada. Entretanto, da transformação do mundo do trabalho cotidiano para a transformação social revolucionária, ainda há um abismo a ser atravessado. As possibilidades de modificação da vida cotidiana no capitalismo moderno estavam apenas esboçadas, dadas num estágio que pode ser chamado de "embrionário", visto que as transformações do mundo dos objetos patrocinadas pela "intelligentsia técnica" visavam apenas à maximização dos lucros e à otimização do processo produtivo. Todavia, o teórico já enxerga nesse movimento, um enfraquecimento do poder fetichista da forma mercadoria.

Dado esse panorama, a tarefa do proletariado seria criar novas formas de organização da vida cotidiana, na qual objetos e ferramentas de trabalho e ensino seriam sistematicamente regulados e reinventados. Criar estruturas de sociabilidade capazes de assimilar e superar os avanços suscitados pelas dinâmicas de trabalho fordistas e tayloristas e desenvolver uma engenharia social de inspiração socialista, pensada a partir da cultura material do trabalhador proletário. Para o teórico, apenas quando as forças produtivas da humanidade forem operadas por mecânicos, eletricistas, maquinistas, motoristas, etc., o domínio dos objetos será diretamente conectado às pessoas e às forças da natureza, provendo à sociedade com o máximo de economia de energia, e com o máximo das possibilidades organizativas. 


\section{CONCLUSÃ̃O}

A pesquisa realizada demonstrou que a teoria da "montagem de atrações" de Eisenstein se constituiu num modo de construção artística, nos âmbitos do teatro e do cinema, que tinha como diretriz o trabalho com as emoções do espectador. Tal forma de práxis artística fundava-se numa certa noção de "função social da arte", pautada pelo conceito de "encomenda social" e pelo contexto revolucionário soviético, bem como ligava-se à nova escala da luta de classes, na chave posta pela implementação da NEP.

Tal como indica o cineasta, em 1925, a "montagem de atrações", aplicada no cinema, é um Método de Realização de um Filme Operário. Nesse sentido, $A$ Greve - primeiro filme no qual tal método foi aplicado - se constituiu em forte ligação com as questões operárias, a saber: com o tema crucial da sua organização política independente, e, deste modo, vinculado ao debate sobre a construção da cultura proletária, posto pela Proletarskaia Kultura, a partir da idéias de Alexander Bogdanov.

Tanto Sergei Tret'iakov quanto Boris Arvatov - duas das influências mais importantes na formação e na prática teatral de Eisenstein - foram membros atuantes da Proletkult, e suas concepções teóricas sobre o campo da arte (a "encomenda social" e a "teoria do objeto socialista", respectivamente) podem ser pensadas como propostas que tinham por objetivo orientar a práxis artística para a execução de tarefas úteis para organização do operariado. Para Tret'iakov, bem como para Arvatov, a produção artística poderia ser capaz de influir sobre a vida cotidiana do trabalhador soviético. Seja no campo da 
educação e da agitação política (a "encomenda social" de Tret'iakov), quanto no da reformulação das relações de consumo e na luta contra o fetiche da mercadoria (no caso, dos objetos, ou da "coisa" - a vechtch - socialista de Arvatov).

Em conseqüência, pode-se supor que $A$ Greve (Stachka), o filme - que traz título muito próximo à obra Greves de Valerian Pletnev (Stachki, peça de teatro escrita em 1921) ${ }^{207}$ - e o Clube dos Trabalhadores, de Rodchenko, participam do mesmo processo de construção da organização operária independente, não apenas porque estes trabalhos foram realizados no mesmo período (1924-1925) e em colaboração com a Proletkult, mas também porque ambos tinham por objetivo a transformação radical da experiência do trabalhador.

No caso específico de Eisenstein, a sua ligação com a Proletkult se mostra decisiva para uma avaliação do contexto sócio-político no qual $A$ Greve se inseria. Embora seja possível afirmar que a teoria da "montagem de atrações" consistiu numa realização individual do cineasta - tal como observa Tret'iakov, em Teatr attraktsionov (Teatro de Atrações, artigo publicado em 1924) ${ }^{208}$ - considerar A Greve como um trabalho artístico unicamente autoral e dissociado do debate histórico e coletivo sobre a cultura operária (e as suas implicações no contexto da luta de classes no período da NEP) é denegar o conteúdo político do filme, assim como o seu enraizamento histórico.

\footnotetext{
${ }^{207}$ Ver A. K. Kolesova, "Prakticheskaia deiatel'nost' rabochego kluba v 1917-1920 godakh," Uchenye zapiski Moskovskogo gosudarstvennogo instituta kul'tury, vol. 17 (1968), p. 244, apud. MALLY, Lynn, Op. Cit., p. 142.

${ }^{208}$ TRET'IAKOV, Sergei, "The Theater of Attractions", in October 118, Fall 2006, Cambridge, MIT Press, pp. 19-26. Artigo publicado originalmente na revista Oktiabr' mysli, n‥ 1, 1924, pp. 53-57.
} 


\section{BIBLIOGRAFIA CONSULTADA}

Textos de Sergei M. Eisenstein: artigos publicados, coletâneas de ensaios, etc.

EISENSTEIN, Sergei, TAYLOR, Richard (Ed. e trad.), S. M. Eizenshtein Writings, 1922-34, London, BFI Publishing, 1987.

EISENSTEIN, Sergei, SLIWOWSKI, Maciej (Trad.), LEYDA, Jay (Trad.), MICHELSON, Annette (Trad.), "Notes for a Film of 'Capital"', in OCTOBER 2, Cambridge, MA, MIT Press, Summer 1976, pp. 3-26.

EISENSTEIN, Sergei, A forma do filme, São Paulo, Jorge Zahar Editor, 2002.

EISENSTEIN, Sergei, O sentido do filme, São Paulo, Jorge Zahar Editor, 2002.

EISENSTEIN, Sergei, "EI montaje de atraciones", in RAMIÓ, Joaquim (org.), THEVENET, Homero (org.), Textos y Manifestos del Cine, Madrid, Ediciones Cátedra S.A., 1993, p. 72-75.

EISENSTEIN, Sergei, ZOUBOFF, Anne (trad.), ALBERA, François (intro.), Cinématisme, peiture et cinema, textes inédits, Buxelles, Éditions Complexe, 1980.

\section{Estudos sobre a obra cinematográfica e a obra teatral de Eisenstein}

ALBERA, François, Eisenstein e o Construtivismo Russo, trad. Eloísa Araújo Ribeiro, pref. Luiz Renato Martins, São Paulo, Cosac \& Naify Edições, 2002.

AUMONT, Jacques, Montage Eisenstein, Paris, Editions Albatros, 1979.

BORDWELL, David, The Cinema of Eisenstein, Cambridge, MA, Harvard University Press, 1996. 
BOWES, Malcolm, Eurhythmics and the analysis of visual-musical synthesis in films: an examination of Sergei Eisenstein's Alexander Nevski, PhD Thesis, Ohio University, 1978.

BOTSFORD, David, "Collectivism versus romanticism in the early cinema: Sergei Eisenstein and the 'mass-hero'", in Cultural Notes No. 25, London, Libertarian Alliance, 1991, pp. 1-14.

BRILEY, Ron, "Sergei Eisenstein: the artist in service of the revolution", in The History Teacher, Vol. 29, No. 4, Long Beach, CA, The Society for the History Education, 1996, pp. 525-536.

CLARK, Katerina, "Eisenstein's two projects for a film about Moscow", in Modern Language Review, No. 101, Modern Humanities Research Association, 2006, pp. 184200.

DOHERTY, Thomas, "An American tragedy: the shotgun wedding of Moscow and Hollywood", in History Today, London, History Today Ldt., May 2002, pp. 31-37.

FRAMPTON, Hollis, "Film in the House of the Word", in OCTOBER 17, Cambridge, MA, MIT Press, Summer 1981, pp. 61-64.

GOODWIN, James, "Eisenstein, Ecstasy, Joyce, and Hebraism", in Critical Inquiry 26, University of Chicago, 2000, pp. 529-557.

GEROULD, Daniel, "Eisenstein's 'Wiseman'", in The Drama Review: TDR, Vol. 18, No. 1, Cambridge, MA, The MIT Press, 1974, pp. 71-76.

GORDON, Mel, "Eisenstein's Later Work at the Proletkult", in The Drama Review: TDR, Vol. 22, No. 3, Cambridge, MA, The MIT Press, 1978, pp. 107-112.

IAMPOLSKI, Mikhail, "Theory as Quotation”, in OCTOBER 88, Cambridge, The MIT Press, 1999, pp. 51-68. 
KEPLEY Jr., Vance, "The Evolution of Eisenstein's 'Old and New'", in Cinema Journal, Vol. 14, No. 1, Austin, University of Texas Press on behalf of the Society for Cinema \&amp; Media Studies, 1974, pp. 34-50.

KUIPER, John B., "Eisenstein's 'Strike': A Study of Cinematic Allegory", in The Journal of the Society of Cinematologists, Vol. 3, Austin, University of Texas Press on behalf of the Society for Cinema \&amp; Media Studies, 1963, pp. 7-15.

MACHADO, Arlindo, Eisenstein: geometria do êxtase, São Paulo, Brasiliense, 1982.

MICHELSON, Annette, "Reading Eisenstein Reading 'Capital'", in OCTOBER 2, Cambridge, MA, MIT Press, Summer 1976, pp. 26-38.

MICHELSON, Annette, "Reading Eisenstein Reading 'Capital' (Part 2)", in OCTOBER 3, Cambridge, MA, MIT Press, Spring 1977, pp. 82-89.

MICHELSON, Annette, "Eisenstein at 100: Recent Reception and Coming Attractions", in OCTOBER 88, Cambridge, MA, The MIT Press, Spring 99, pp. 69-85.

NEWCOMB, James, "Eisenstein's Aesthetics", in The Journal of Aesthetics and Art Criticism, Vol. 32, No. 4, Philadelphia, The American Society for Aesthetics, 1974, pp. 471-476.

OELER, Karla, "A collective interior monologue: Sergei Parajanov and Eisenstein's Joyce-inspired vision of cinema", in Modern Language Review, No. 101, Leeds, Maney Publishing, 2006, pp. 472-487.

ROBÉ, Chris, "Eisenstein in America: The Qué Viva México! Debates and the emergent popular front in U.S. film theory and criticism", in The Velvet Light Trap, Number 54, Austin, University of Texas Press, Fall 2004, pp. 18-31.

RUSSO, Eduardo, "La máquina de pensar: Notas para una genealogía de la relación entre teoría y prática en Sergei Eisenstein", in Cuadernos del Centro de Estudios en Diseño y Comunicación, № 15, Buenos Aires, Universidade de Palermo, 2003, pp. 5968. 
SETON, Marie, "Second thoughts on Eisenstein", in Soviet Studies, Vol. 6, No. 2, London, Taylor \& Francis Ltd., 1954, p. 113-123.

SORENSEN, Janet, "Lef, Eisenstein, and the Politics of Form", in Film Criticism, No. 19, Meadville, Allegheny College, Winter 94/95, pp. 55-74.

STOLLERY, Martin, "Eisenstein, Shub and the gender of the author as producer", in Film History, Vol. 14, No. 1, Bloomington, Indiana University Press, 2002, pp. 87-99.

VLADMIR, Nizhny, MONTAGU, Ivor (trad.), LEYDA, Jay (trad.), Lessons with Eisenstein, New York, Hill and Wang, 1969.

\section{Estudos sobre o construtivismo russo}

BOIS, Yve-Alain, HUBERT, Christian (trad.), "El Lissitzky: Reading Lessons", in OCTOBER 11, Cambridge, MA, MIT Press, Winter 1979, pp. 113-128.

BOWLT, John, "Russian art in the nineteen twenties", in Soviet Studies, Vol. 22, No. 4, London, Taylor \& Francis Ltd., 1971, pp. 575-594.

BOWLT, John E., "Constructivism and Russian Stage Design", in Performing Arts Journal, Vol. 1, No. 3, The MIT Press on behalf of the Performing Arts Journal Inc., Winter 1977, pp. 62-84

BUCHLOCH, Benjamin H. D., "Cold war constructivism", in Serge GUILBAUT (ed.), Reconstructing Modernism/Art in New York, Paris and Montreal 1945-1964, Cambridge, Massachusetts, MIT Press, 1991, pp. 85-110.

GOUGH, Maria, The Artist as Producer: Russian Constructivism in Revolution, Berkley, Ca, University of California Press, 2005.

GOURIANOVA, Nina, The early Russian avant-garde 1908-1918: the aesthetics of anarchy, PhD Thesis, Columbia University, 2001. 
GOUGH, Maria, "Futurist museology", in Modernism/Modernity, Vol. 10, No. 2, Baltimore, John Hopkins University Press, 2003, pp. 327-348.

GOUGH, Maria, "Tarabukin, Spengler, and the Art of Production", in OCTOBER 93, Cambridge, MA, The MIT Press, 2000, pp. 78-108.

GOUGH, Maria, "In the Laboratory of Constructivism: Karl loganson's Cold Structures", in OCTOBER 84, Cambridge, MA, MIT Press, Spring 1998, pp. 90-117.

KIAER, Christina, "Boris Arvatov's Socialist Objects", in OCTOBER 81, Cambridge, MA, MIT Press, Summer 1997, pp. 105-118.

KIAER, Christina, "The Russian Constructivism Flapper Dress", in Critical Inquiry, Vol. 28, No. 1, The University of Chicago Press, Autumn 2001, pp. 185-243.

KIAER, Christina. The Russian Constructivist "Object" and the Revolutionizing of Everyday Life, PhD Thesis, Berkley, University of California, 1995.

KIAER, Christina, "Rodchenko in Paris", in OCTOBER 75, Cambridge, MA, MIT Press, Winter 1996, pp. 3-35.

KOLCHEVSKA, Natasha, Lef and Developments in Russian Futurism in the 1920's, PhD Thesis, Berkley, University of California, 1995.

KOLCHEVSKA, Natasha, "From Agitation to Factography: The Plays of Sergej Tret'jakov", in Slavic and East European Journal, Vol. 31, No.3, Lexington, KY, American Association of Teachers of Slavic and East European Languages, 1987, pp. 388-403.

KURCHANOVA, Natasha, Against Utopia: Osip Brik and the Genesis of Productivism, PhD Thesis, New York, The City University of New York, 2005.

LODDER, Christina, Russian Constructivism, New Haven, Yale University Press, 1990. 
MIGUEL, Jair Diniz, Arte, Ensino, Utopia e Revolução: Os Ateliês Artísticos Vkhutemas/Vkhutein (Rússia/URSS, 1920-1930), Tese de Doutorado, São Paulo, Universidade de São Paulo, 2006.

ROWELL, Margit, "Vladimir Tatlin: Form/Faktura", in OCTOBER 7, Cambridge, MA, MIT Press, Winter 1978, pp. 83-108.

RUDER, Adam, Art and the Shaping of Society: Russian Posters and Constructivism 1917-1924, Haverford, Senior Thesis, Haverford College, 2003.

SHARP, Jane A., "The Russian Avant-Garde and Its Audience: Moscow, 1913", in Modernism/modernity, Vol. 6, No. 3, Baltimore, John Hopkins University Press, September 1999, pp. 91-116.

STEPAHN, Halina, "Lef and the development of the early soviet prose", in The Slavic and East European Journal, Vol. 24, No. 4, Lexington, KY, American Association of Teachers of Slavic and East European Languages, 1980, pp. 369-386.

TUPITSYN, Margarita, The function of the soviet photograph: 1924-1937, PhD Thesis, The City University of New York, 1996.

WOLF, Erika, USSR in construction: from avant-garde to socialist realist practice, $\mathrm{PhD}$ Thesis, University of Michigan, 1999.

ZALAMBANI, Maria, "Boris Arvatov, Théoricien du productivisme", in Cahiers du Monde russe, Vol. 40, No. 3, Paris, Éditions de l'EHESS, 1999, pp. 415-446.

Traduções e compilações de textos de artistas, historiadores, teóricos, e cineastas construtivistas, redigidos durante a década de 1920.

ARVATOV, Boris, Arte y produccion, el programa del productivismo, Madrid, Corazón, 1973. 
ARVATOV, Boris, KIAER, Christina (trad.), "Everyday Life and the Culture of the Thing (Toward the Formulation of the Question)", in OCTOBER 81, Cambridge, MA, MIT Press, Summer 1997, pp. 119-128.

BOWLT, John E. (Ed. and transl. by), Russian Art of the Avant-Garde Theory and Criticism 1902-1934, New York, The Viking Press, 1976.

LUNACHARSKY, A. V., SUMERKIN, Alexander (trad.), "Review: Gogol-Meyerhold's 'The Inspector-General'", in OCTOBER 7, Soviet Revolutionary Culture, Cambridge, MA, The MIT Press, pp. 57-70.

TRET'IAKOV, Sergei, "Art in the Revolution and the Revolution in Art (Aesthetic Consumption and Production)", in OCTOBER 118, Fall 2006, Cambridge, MA, MIT Press, pp. 11-18.

TRET'IAKOV, Sergei, "Our Cinema", in OCTOBER 118, Fall 2006, Cambridge, MA, MIT Press, pp. 27-44.

TRETYAKOV, Sergei, HIRSCH, Liudmilla (Trad.), "Do You Hear, Moscow?", in The Drama Review: TDR, Vol. 22, No. 3, Cambridge, MA, The MIT Press, 1978, pp. 113126.

TRET'IAKOV, Sergei, "The Theater of Attractions", in OCTOBER 118, Fall 2006, Cambridge, MA, MIT Press, PP. 19-26.

TARABUKIN, Nikolai, BARLETT, Rosamud (trad.), GOUGH, Maria (intro.), "The Art of the Day", in OCTOBER 93, Cambridge, MA, MIT Press, Summer 2000, pp. 57-77.

TARABOUKINE, Nikolaï, "Du chevalet à la machine" in idem, Le Dernier Tableau/ "Du chevalet à la machine"; "Pour une théorie de la peinture"/ écrits sur l'art et l'historie de l'art à l'époque du construtivisme russe", apr. A. B. Nakov, trad. M. Pétris e A. B. Nakov, Paris, Champ Libre, 1980.

VERTOV, Dziga, O'BRIAN, Kevin (trad.), "The Factory of Facts and Other Writings", in OCTOBER 7, Cambridge, MA, MIT Press, Winter 1978, pp. 109-128. 


\section{Estudos introdutórios, críticos e históricos sobre o campo das teorias do cinema do século $X X$}

ANDREW, J. Dudley. As principais teorias do cinema: uma introdução. Rio de Janeiro: Jorge Zahar Editor, 2002.

BELLER, Jonathan L.. The cinematic mode of production, PhD Thesis, Duke University, 1994.

BELLER, Jonathan L., "The Spectatorship of the Proletariat", in boundary 2, Vol. 22, No. 3, Duke University Press, Autumn 1995, pp. 171-228.

BOTSFORD, David, "Romanticism and its enemies in twentieth century cinema", in Cultural Notes No. 30, London, Libertarian Alliance, 1992, pp. 1-10.

GUNNING, Tom, "The Cinema of Attractions: Early Film, Its Spectator and the AvantGarde", in ELSAESSER, Thomas (org.), Early Cinema: Space, Frame, Narrative, London, BFI Publishing, 1992, p. 56-62.

HARRAH, David, "Aesthetics of the film: the Pudovkin-Arnheim-Eisenstein theory", in The Journal of Aesthetics and Art Criticism, Vol. 13, No. 2, The American Society for Aesthetics, 1954, pp. 163-174.

MITRY, Jean, História del Cine Experimental, Valencia, Fernando Torres Editor, 1974, pp. 121-148.

XAVIER, Ismail, O discurso cinematográfico: a opacidade e a transparência, São Paulo, Paz e Terra, 2005. 


\section{Estudos sobre a história e a estética do cinema soviético das décadas de 1920 e 1930}

BILBATÚA, Miguel (org.), Cine sovietico de vanguardia, teoria y lenguage, Madrid, A. Corazón, 1971.

BOHLIGER, Vincent, Compromising Kino: The Development of Socialist Realist Film Style in the Soviet Union, 1928-1935, PhD Thesis, University of Wisconsin-Madison, 2007.

BORDWELL, David, "The Idea of Montage in Soviet Art and Film", in Cinema Journal, Vol. 11, No. 2, Austin, University of Texas Press on behalf of the Society for Cinema \&amp; Media Studies, 1972, pp. 9-17.

BURCH, Noël, "Film's intitutional Mode of Representation and the Soviet Response", in OCTOBER 11, Cambridge, MA, MIT Press, Winter 1979, pp. 77-96.

ERSTAD, Lorren, "The Storming of the Winter Palace": Bolshevik Agitation and Propaganda, 1917-1928, PhD Thesis, New York, New York University, 1996.

KEPLEY Jr., Vance, "Federal Cinema: The Soviet Film Industry, 1924-32" in Film History, Vol. 8, No. 3, Bloomington, Indiana University Press, 1996, pp. 334-356.

FELDMANN, Martha, "Totalitarism without pain: teaching communism and fascism with film", in The History Teacher, Vol. 29, No. 1, Society for the History of Education, 2005, pp. 51-61.

GILLESPIE, David, "The sounds of music: soundtrack and song in soviet film", in Slavic Review, Vol. 62, No. 3, The American Association for the Advancement of Slavic Studies, 2003, pp. 473-490.

HARTE, Timothy. Russian motion: kinetic dynamism and speed in Russian avantgarde poetry, painting, and film. PhD Thesis, Harvard University, 2001.

LEDA, JAY, Kino: historia Del cine ruso y soviético, Buenos Aires, Ed. Universitaria de Buenos Aires, 1965. 
MINI, Panayiota, Pudovkin's Cinema of the 1920's, PhD Thesis, University of Wisconsin-Madison, 2002.

MILLER, Jamie, "The purges of soviet cinema, 1929-38", in Studies in Russian and Soviet Cinema, Vol. 1, No. 1, 2007, London, Intellect Ltd., pp. 5-26.

YOUNGBLOOD, Denise, Soviet Cinema in the Silent Era 1918-1935, Austin, University Of Texas Press, 1991.

\section{Estudos sobre a obra cinematográfica de Dziga Vertov}

COOK, Simon, "'Our Eyes, Spinning Like Propellers': Wheel of Life, Curve of Velocities, and Dziga Vertov's 'Theory of the Interval', in OCTOBER 121, Cambridge, MA, MIT Press, Summer 2007, pp. 79-91.

PETRIC, Vlada, Constructivism in Film: The Man with the Movie Camera: A Cinematic Analysis, Cambridge, Cambridge University Press, 1987, pp. 1-69.

PRUNES, Mariano, “Dziga Vertov's Three Songs About Lenin (1934): a visual tour through the history of the soviet avant-garde in the interwar years", in Criticism, Vol. 45, No. 2, Detroit, Wayne State University Press, 2003, pp. 251-278.

SARKISOVA, Oksana, "Across One Sixth of the World: Dziga Vertov, Travel Cinema, and Soviet Patriotism", in OCTOBER 121, Cambridge, MA, MIT Press, Summer 2007, pp. 19-40.

TURVEY, Malcolm, "Can the Camera See? Mimesis in 'Man with the Movie Camera'", in OCTOBER 89, Cambridge, MA, MIT Press, Summer 1999, pp. 25-50.

TURVEY, Malcolm, "Vertov: Between the Organism and the Machine", in OCTOBER 121, Cambridge, MA, MIT Press, Summer 2007, pp. 5-18. 